INTERNATIONAL MONETARY FUND
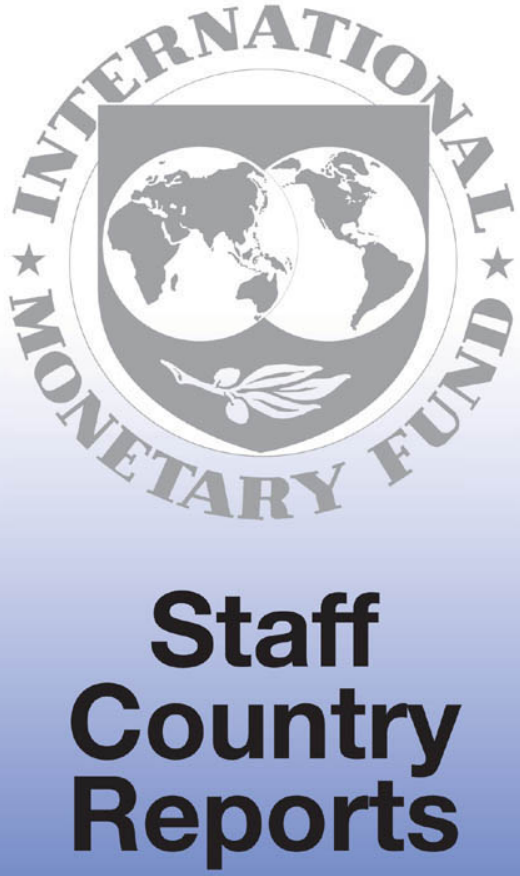


\section{Bangladesh: Recent Economic Developments}

This Recent Economic Developments report on Bangladesh was prepared by a staff team of the International Monetary Fund as background documentation for the periodic consultation with this member country. As such, the views expressed in this document are those of the staff team and do not necessarily reflect the views of the Government of Bangladesh or the Executive Board of the IMF.

Copies of this report are available to the public from International Monetary Fund $\bullet$ Publication Services 70019 th Street, N.W. - Washington, D.C. 20431

Telephone: (202) 623-7430 - Telefax: (202) 623-7201

Telex (RCA): 248331 IMF UR

E-mail: publications@imf.org

Internet: http://www.imf.org

Price: $\$ 15.00$ a copy

\section{International Monetary Fund Washington, D.C.}




\section{INTERNATIONAL MONETARY FUND}

\section{BANGLADESH}

\section{Recent Economic Developments}

Prepared by Birgir Arnason (APD), Era Dabla-Norris (FAD), Jens Dalsgaard (PDR), Ronald Hicks, and Lazaros E. Molho (both APD)

Approved by the Asia and Pacific Department

January 10,2000

Contents

Basic Data, 1994/95-1998/99. 4

Social Indicators 5

I. Introduction and Overview 6

II. Real Sector Developments...

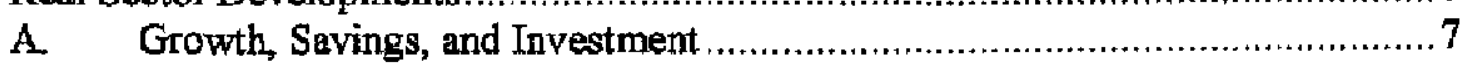

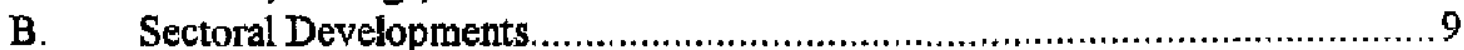

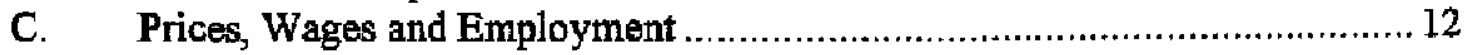

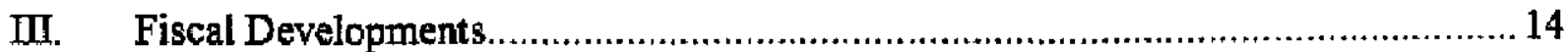

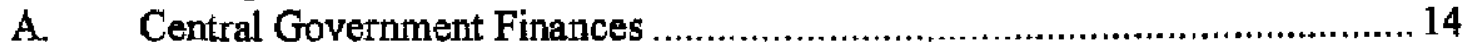

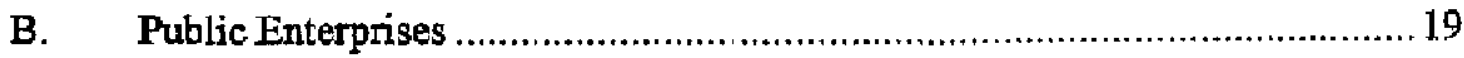

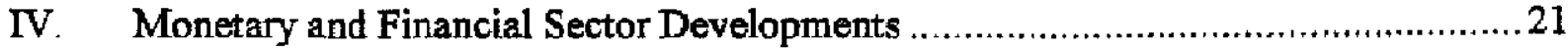

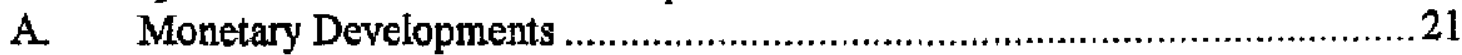

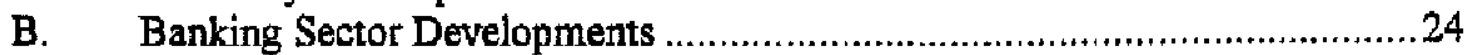

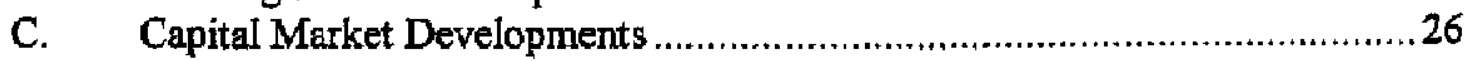

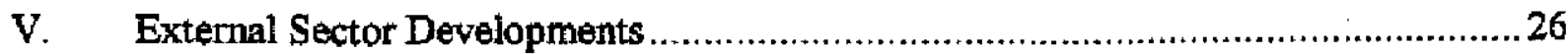

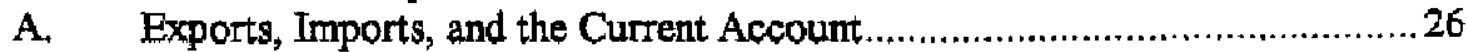

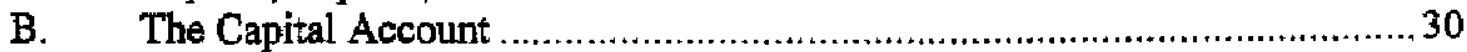

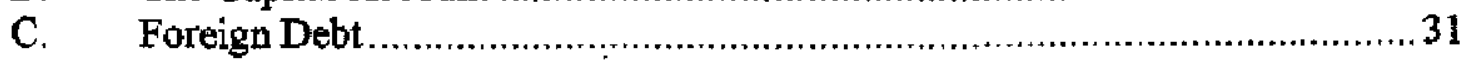

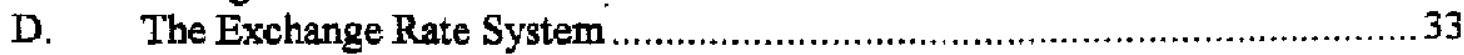

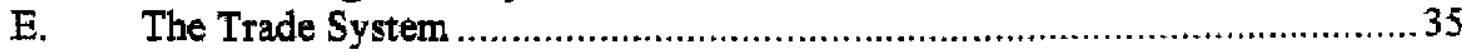


Text Boxes

1. Tax Measures in the $1999 / 2000$ Budget .................................................. 18

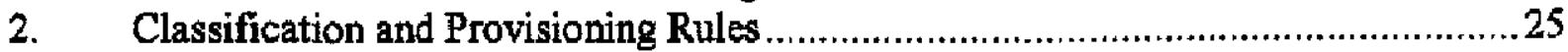

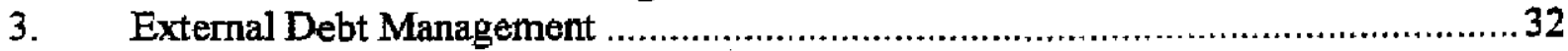

\begin{tabular}{|c|c|}
\hline & \\
\hline 1. & Growth and Inflation. \\
\hline 2. & 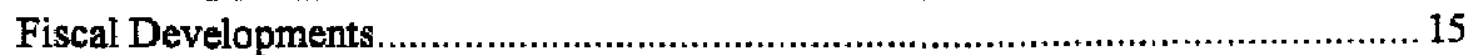 \\
\hline 3. & Monetary Developments.... \\
\hline 4. & External Sector Developments ................... \\
\hline 5 & Exchange Rates and Official Reserves .... \\
\hline
\end{tabular}

Tables

1. Gross Domestic Product at current Prices, 1994/95-1998/99 ............................38

2. Sectoral Growth Rates at Constant Prices, 1994/95-1998/99 ........................ 39

3. Gross Domestic Product by Expenditure at Current Prices, 1994/95-1998/99 .........40

4. Agricultural Production, 1994/95-1998/99 ...........................................41

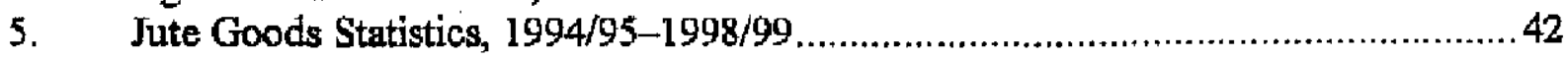

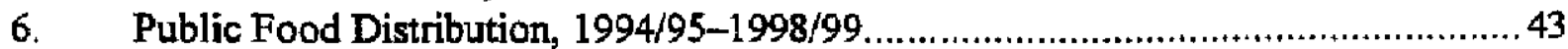

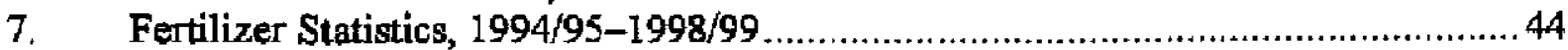

8. Manufacturing Production by Main Categories, 1994/95-1998/99 _..................45

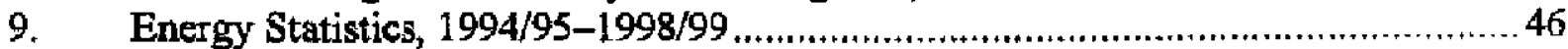

10. Retail Prices of Petroletsm Products, $1994 / 95-1998 / 99, \ldots \ldots \ldots \ldots \ldots \ldots \ldots \ldots \ldots \ldots \ldots . \ldots 7$

11. Consumer Price Index, National, 1985/86-1999/2000 ..............................48

12. Labor Market Statistics, 1990/91-1995/1996 ..........................................49

13. Central Government Operations, 1994/95-1999/2000..................................... 50

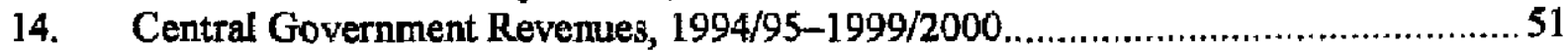

15. Central Government Current Expenditure by Economic Classification, 1994/95-1999/2000 ........................................................................ 52

16. Annual Development Program by Sector, 1994/95-1999/2000 ...................... 53

17. Central Government Food Account, 1994/95-1999/2000 ........................... 54

18. Consolidated Accounts of Nonfinancial Public Enterprises, 1994/95-1999/2000 .... 55

19. Profits of Nonfinancial Public Enterprises, 1994/95-1999/2000 ...................... 56

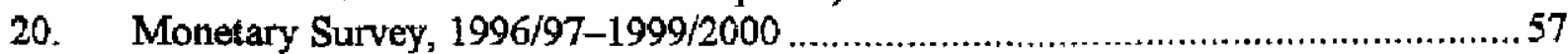

21. Accounts of the Monetary Authorities, 1994/95-1998/99 ...........................58

22. Reserves of Deposit Money Banks, 1994/95-1998/99 ..................................59

23. Interest Rate Structure of the Banking Sector, 1994/95-1998/99 ...................60

24. Interest Rate Structure of Nonbank Financial Institutions and Government

Debt, 1994/95-1998/99

25. Deposit Money Banks' Credit By Economic Sector, 1994/95-1998/99 ...............62

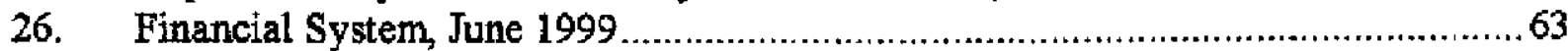

27. Agricultural Credit Disbursement and Recovery, 1994/95-1998/99 ................64

28. Industrial Loan Recovery by Bangladesh Shilpa Bank, 1994/95-1998/99 ............. 65

29. Summary Performance Indicators in the Banking System, 1994-99...................66 
30. Commercial Bank Loan Classification and Provisioning, 1994-1999..................67

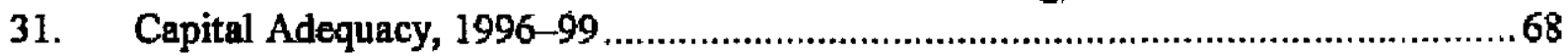

32. Balance of Payments, 1994/95-1998/99 .............................................69

33. Exports by Main Product Categories, 1994/95-1998/99 ..................................70

34. Imports by Main Product Categories, 1994/95-1998/99..............................71

35. Geographical Distribution of Foreign Trade, 1994/95-1997/98 $\ldots \ldots \ldots \ldots \ldots \ldots \ldots \ldots \ldots .72$

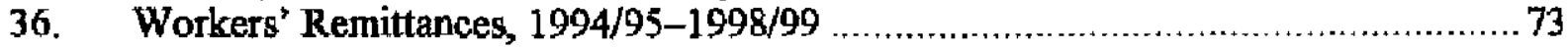

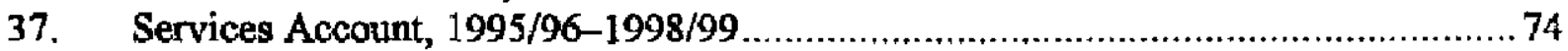

38. External Aid Commitments and Disbursements, 1994/95-1998/99 ...................75

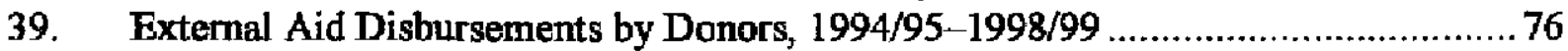

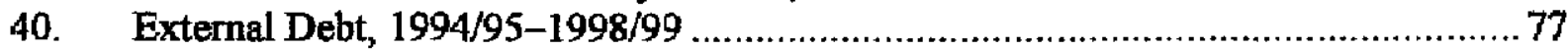

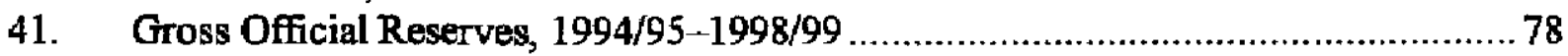


Bangladesin: Basic Data, 1994/95-1998/99 1/

$\begin{array}{ll}\text { Lund ares: } & 147,570 \text { square kilometers } \\ \text { GDP (1998/99): } & \text { US\$44 bjllion } \\ \text { ODP per capita (1998/99): } & \text { US\$345 } \\ \text { Population (1998): } & 126 \text { million } \\ \text { Quotu : } & \text { SDR 392.5 million }\end{array}$

$\begin{array}{lllll}1994 / 95 & 1995 / 96 & 1996 / 97 & 1997 / 98 & 1998 / 99\end{array}$

Est.

National incomo and prioes (persont oinange)

Roal GDP 2

Infiation (annual average)

Central government budget (percent of GDP)

Total revenue

Tax

Total expenditure

Current expenditure

Food account balance

Annulal Development Program

Ofher ospital and net lending

Overall belance

Incl. grants

Domestic funsucing

Banks

Foreign fimancing

Central gowernment debt

Money and credit (end-ytar, pureent change)

Donestic credit

Private sector

Broad money

Balance of payments (USS mn.)

Fxports, fio.b.

(Annulal percent change)

Imports, c.i.f.

(Annural peroent change)

Current acoount (incl. current transfars) 3 (Percent of GDP)

Foreign investment

Aid disbursements (loans and cupital tranfars)

Overalt halance

Gross official reserves (USs $\mathrm{mm}$.)

(In months of imports)

Medium and long-term extetual debt (US\$ mn)

Total debt (percent of ODP)

Debt service (percent of current earnings)

$\begin{array}{lllll}5.9 & 4.6 & 5.4 & 5.2 & 4.2 \\ 8.9 & 6.6 & 2.6 & 7.0 & 9.0\end{array}$

$\begin{array}{lllll}9.4 & 9.1 & 9.4 & 9.6 & 9.5\end{array}$

$\begin{array}{lllll}7.4 & 7.3 & 7.5 & 7.6 & 7.6\end{array}$

$\begin{array}{lllll}14.7 & 13.5 & 13.8 & 13.8 & 14.6\end{array}$

$\begin{array}{lllll}6.8 & 6.9 & 7.0 & 7.4 & 8.0\end{array}$

$\begin{array}{lllll}0.5 & 0.3 & 0.2 & 0.2 & 0.3\end{array}$

$\begin{array}{lllll}6.7 & 5.8 & 6.1 & 5.8 & 5.9\end{array}$

$\begin{array}{llllll}0.8 & 0.5 & 0.5 & 0.4 & 0.3\end{array}$

$\begin{array}{lllll}-5.3 & -4.5 & -4.4 & -4.2 & -5.1\end{array}$

$\begin{array}{lll}-2.7 & -2.9 & -3.7\end{array}$

$\begin{array}{lllll}1.5 & 1.7 & 1.5 & 1.7 & 2.1\end{array}$

$\begin{array}{lllll}0.3 & 0.9 & 1.0 & 0.7 & 1.0\end{array}$

$\begin{array}{lllll}3.8 & 2.8 & 2.9 & 2.5 & 2.6\end{array}$

$\begin{array}{lllll}53.3 & 49.3 & 47.2 & 44.5 & 47.7\end{array}$

$\begin{array}{rrrrr}23.2 & 20.4 & 13.7 & 12.6 & 13.1 \\ 25.0 & 20.8 & 12.1 & 13.0 & 13.8 \\ 16.0 & 8.2 & 10.8 & 10.4 & 12.8\end{array}$

$\begin{array}{lllll}3,473 & 3,882 & 4418 & 5172 & 5324\end{array}$

$\begin{array}{lllll}37.1 & 11.8 & 13.8 & 17.1 & 2.9\end{array}$

$\begin{array}{lllll}5,834 & 6,881 & 7162 & 7520 & 8337\end{array}$

$\begin{array}{lllll}39.2 & 17.9 & 4.1 & 5.0 & 10.9\end{array}$

$\begin{array}{lllll}-728 & -1,316 & -543 & -249 & -823\end{array}$

$\begin{array}{lllll}-1.9 & -3.3 & -1.3 & -0.6 & -1.9\end{array}$

$\begin{array}{lllll}-14 & -120 & 336 & 653\end{array}$

$\begin{array}{lllll}1,375 & 1,124 & 1133 & 1075 & 1215\end{array}$

$\begin{array}{lllll}232 & -901 & -163 & 82 & -171\end{array}$

$3,070 \quad 2,039 \quad 1,719 \quad 1,733 \quad 1,523$

$\begin{array}{lrrrr}6.3 & 3.6 & 2.7 & 2.6 & 2.1\end{array}$

$16,767 \quad 15,170 \quad 15,025 \quad 14,019 \quad 15,144$

$\begin{array}{lllll}44.6 & 37.6 & 36.3 & 32.8 & 35.0\end{array}$

$\begin{array}{llllll}10.4 & 9.4 & 8.7 & 8.0 & 7.9\end{array}$

$\begin{array}{lllll}-0.2 & 0.4 & 7.2 & 2.2 & -4.3\end{array}$

3

Terms of trade

Sorarces: Bangladesh authorities; and Fund staff estimates.

V Fiscal year begins kuly 1.

2/ National accounts bused on 1989/90 benchmark and prices.

3/ Previously cunent transfers were reported in the capital actount. 
Bangladesh: Social Indicators

\begin{tabular}{|c|c|c|}
\hline & 1980 & $\begin{array}{c}\text { Recent } \\
\text { Estimates } U\end{array}$ \\
\hline \multicolumn{3}{|l|}{ Human resources } \\
\hline Population (millions) & 87 & 1262 \\
\hline Age dependency ratio & 1.0 & 0.8 \\
\hline Urban (in percent of population) & 11.3 & 18.9 \\
\hline Population growth rate & 2.5 & $1.62 i$ \\
\hline Urban & 6.1 & 4.7 \\
\hline \multicolumn{3}{|l|}{ Natural resources } \\
\hline Density (population per sq. km) & 666 & $9652 i$ \\
\hline Cropland (percent of ]and area) & 70 & 67 \\
\hline \multicolumn{3}{|l|}{ Income distribution } \\
\hline Share of top 20 percent (percent of total income) & 45.3 & $37.93 /$ \\
\hline Share of bottom 20 percent (percent of total income) & 6.6 & 9.431 \\
\hline \multicolumn{3}{|l|}{ Fuel and power } \\
\hline Energy consumption per capita (kg of oil eq.) & 32 & 67 \\
\hline \multicolumn{3}{|l|}{ Poverty (headcount index in percent of population) } \\
\hline National & 49.9 & 35.6 \\
\hline Rural & 52.2 & 39.8 \\
\hline Uthan & 30.7 & 14.3 \\
\hline \multicolumn{3}{|l|}{ Education } \\
\hline \multicolumn{3}{|l|}{ Gross enrollment ratios } \\
\hline Primary (percent of school age) & 61 & 92 \\
\hline Pupil/teacher ratio & 54 & $634 !$ \\
\hline Secondary (percent of school age) & 18 & $214 !$ \\
\hline Illiteracy (percent of pop. 15+) & 71 & 62 \\
\hline \multicolumn{3}{|l|}{ Health } \\
\hline Hospital bed (per 1,000 people) & 0.2 & 0.3 \\
\hline \multicolumn{3}{|l|}{ Mortality (per thousand live births) } \\
\hline Infants & 132 & $575 /$ \\
\hline Under 5 & 207 & 112 \\
\hline \multicolumn{3}{|l|}{ Immunization (percent chitdren under 12 months) } \\
\hline Measles & 1.0 & 98 \\
\hline DPT & 1.0 & 97 \\
\hline Child malnutrition under $\$$ (percent of age group) & 70 & 68 \\
\hline Iife expectancy (years) & 48 & $60.82 /$ \\
\hline Total fertility rate (births per woman) & 6.1 & $3.36 /$ \\
\hline Maternal mortality rate (per 10,000 live births) & 3,000 & 850 \\
\hline
\end{tabular}

Sources: The World Bank, World Deveiopment Indicators, 1998; and Bangladesh Bureau of Statistics, Statistical Yearbook of Bangladesh 1993.

1/ 1995/96 estimates, unless otherwise indicated.

2/1998 estiantes.

3/1992 estimates.

4/ 1990 estimates.

5/ 1994 estimates.

6/ 1997 estimates. 


\section{INTRODUCTION AND OVERVIEW}

1. Recent economic and financial developments in Bangladesh were greatly marked by the massive floods that struck in July-September 1998. The floods caused heavy damage to infrastructure, wreaked havoc on production and distribution, and resulted in a major disruption of exports. To alleviate the economic and social impact of the floods, the government mounted a large-scale flood relief operation and sharply increased food imports, with considerable donor assistance, including from the Fund in the form of an emergency loan in October 1998. In the end, the setback to output growth and price stability turned out to be less severe than feared. With the help of an unexpectedly bountiful spring rice crop, GDP growth fell only modestly below trend in 1998/99 (July-June) and the upturn in inflation, as a result of higher food prices, was decidedly temporary. However, the recovery of manufacturing activity and exports has remained sluggish in the face of intense competitive pressures and severe infrastructure bottlenecks.

2. Fiscal and monetary policies were adapted in October 1998 under the government's emergency flood assistance program, with a view to funding relief and rehabilitation measures without undermining macroeconomic stability. To keep the overrun in the budget deficit within prudent limits, the revised macroeconomic policy framework for 1998/99 envisaged a number of measures to curtail nonflood-related fiscal expenditures and to raise additional revenues. The monetary program for 1998/99 was designed to accommodate the expected increase in the rate of inflation and to meet the productive sectors' credit needs (including the temporary post-flood credit requirements of the agricultural sector), while also aiming to protect the level of reserves. In the event, both fiscal and monetary policies turned out to be somewhat more expansionary than envisaged in the emergency assistance program. Despite substantial external support, the overall balance of payments shifted into deficit in 1998/99, and the level of official reserves declined to the equivalent of 2.1 months of imports by the end of the fiscal year.

3. Preliminary indications suggest that macroeconomic policies were eased further in the early months of $1999 / 2000$. While inflation has remained on a declining trend, and the extemal current account deficit is likely to have narrowed in the face of declining food imports and weak investment demand, inadequate progress in addressing the economy's structural weaknesses, together with an uncertain political environment, have tended to discourage private and official capital inflows. As a result, the external reserve position remained fragile during the first half of 1999/2000. 


\section{REAL SECTOR DEVELOPMENTS ${ }^{1}$}

\section{A. Growth, Savings, and Investment}

4. Reflecting the impact of the floods the most severe in living memory in Bangladesh_output growth is estimated to have declined in 1998/99 to 4.2 percent (based on the revised national accounts with 1989/90 benchmark), compared with an average of 5.3 percent in the two preceding years (Chart 1 and Tables 1 and 2). Improved weather conditions, together with the government-supported rehabilitation efforts, led to an impressive rebound in agricultural production. In particular, a bumper boro rice crop toward the end of the fiscal year was the principal factor generating a growth rate in $1998 / 99$ considerably higher than the 3 percent projected in the government's post-flood adjustment program. Bangladesh's recent output performance does not appear to have been significantly affected by the Asian crisis.

5. The resilience shown by agriculture, while also evident in some other sectors, such as wholesale and retail trade and construction, was not extended to the manufacturing sector, which had been an engine of growth in previous years. Growth in manufacturing output, which had alseady begun to weaken before the floods, dropped to a significantly negative rate, and began to pick up only in the later months of 1998/99. The slowdown in manufacturing output growth was reflected in a marked deceleration of export growth in 1998/99, particularly in the dominant garments sector. These developments reflected the combined effects of competitive pressures associated with an appreciated real exchange rate, critical infrastructural problems (with respect to power and transportation, in particular), labor difficulties, and the poor financial condition of many industrial (particularly state-owned) enterprises.

6. Private investment growth appears to have decelerated in 1998/99 (Table 3). The available estimates of aggregate demand are subject to a wide margin of error and need to be interpreted with caution. ${ }^{2}$ Nevertheless, the evidence of slowing investment growth is consistent with signs of a weakening of investor confidence, which reflects in large part the lack of visible progress in addressing the country's major structural problems. In 1999, the investment climate has been further undermined by intensified political confrontation and civil unrest caused by a widening rift between the government and the main opposition parties. These developments are disappointing in view of Bangladesh's need to boost economic growth in order to make a substantial dent in the country's pervasive poverty. The slowdown in investment growth was moderated during $1998 / 99$ by the expansion of flood-

\footnotetext{
'Prepared by Ronaid Hicks.

${ }^{2}$ The statistical discrepancy in the national accounts has risen steadily in recent years and rose above 10 percent of GDP in 1998/99, underscoring the need to further strengthen the national accounts estimation process in Bangladesh.
} 
CHART 1. BANGLADESH

GROWTH AND INFLATION
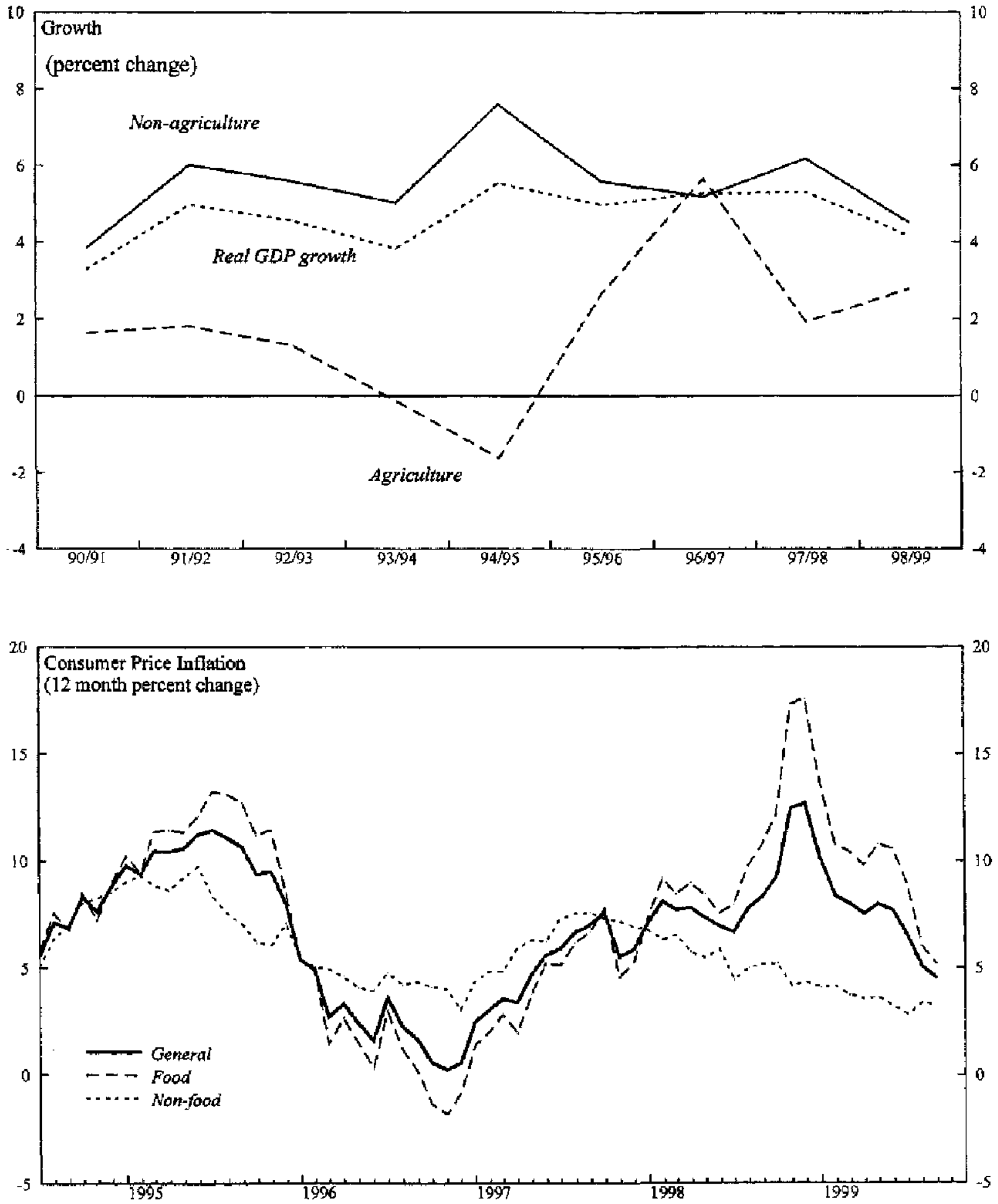

Sources: Bureau of Statistics; and staff estimates. 
related and donor-financed public investment. However, this pattern of investment could prove difficult to sustain in the period ahead. Thus, while gross investment is estimated to have remained at about 22 percent of GDP in 1998/99, the investment-to-GDP ratio would likely decrease in the period ahead if financing constraints and lagging donor support lead to a reversion to a lower pace of public investment.

\section{B. Sectoral Developments}

\section{Agriculture}

7. Foodgrain production is estimated to have risen by nearly 4 percent is 1998/99, compared with 0.5 percent in 1997/98 and an average of 3 percent in the preceding five years. Even with the large decline in the aus and aman rice crops stemming from the floods, which affected about 1.5 million hectares of land in 1998/99, a record boro rice crop of over 10 million metric tons toward the end of the year (compared with 8.1 million tons in 1997/98) contributed to a positive growth of rice output over the year (Table 4). Production of wheat increased strongly to 2.0 million metric tons, compared with 1.8 million tons in 1997/98. Emphasis was placed in $1998 / 99$ on increasing yield per hectare for foodgrain output, rather than increasing crop acreage, achieved through a shift from local variety to high-yielding varieties and hybrid seed. Atogether, foodgrain production is estimated to have risen to 21.3 million metric tons in $1998 / 99$ despite an estimated output loss of about 2 million tons on account of the floods.

8. In these circumstances, and assuming a daily foodgrain requirement of 455 grams per capita per day, a food gap of about 1.9 million tons emerged in 1998/99, of which 1.2 million tons was covered by foreign assistance, and the remainder by government and private imports. Following the floods, the government sought to maintain a food security stock of at least three to four months of foodgrain requirements. To that end, commercial imports of rice more than tripled from 92,000 tons in 1997/98 to 334,000 tons in $1998 / 99$, while wheat imports rose from 155,000 tons in $1997 / 98$ to 429,000 tons in $1998 / 99$.

9. Apart from foodgrain, the second most important camponent of the crop and horticulture subsector-jute-performed poorly in 1998/99, with a decline in output from 560,000 metric tons to $\mathbf{5 1 0 , 0 0 0}$ tons (Table 5). Although the floods were an important contributing factor, a continuing slump in world export prices, together with the entrenched weaknesses in the management of the government-owned Bangladesh Jute Mils Corporation, severely compressed profitability, undermined output performance, and increased the jute sector's overdue bank loans. The 1999/2000 budget envisaged the repayment of some of these loans by the government and a continuing provision of subsidies to cover the wage costs of definct state-owned jute mills. Nevertheless, in the face of a continuing increase in operating losses, the government has also come under pressure to significantly increase the existing subsidies for jute exports.

10. Altogether, value added in agriculture rose by 2.8 percent in $1998 / 99$, compared with 1.9 percent in $1997 / 98$ and 1.7 percent on average in the preceding years of the 
decade. In the non-crop subsector-principally fisheries, livestock, and forestry-growth in value added amounted to 6.3 percent in 1998/99, which was a modest acceleration despite major flood-induced losses in livestock and poultry. While shrimp cultivation was adversely affected by the floods, total inland and marine catches are estimated to have been substantially higher than in the previous year.

\section{In the period ahead, the government plans to continue to support the} agricultural sector through a number of policy interventions, with a view to promoting food self-sufficiency as envisaged in the Fifth Five-Year Plan (1997-2002). The foodgrain: production target for 1999/2000 has been set at 22.3 million metric tons, representing an increase of 4.7 percent from 1998/99. To help meet these objectives, the government is continuing to take steps to ensure adequate supplies of fertilizer at subsidized prices, and prices for internal procurement of rice are continuing to be set to cover the cost of production and a profit margin, albeit at a substantial cost to the budget. Emphasis is also being placed on raising public sector seed distribution, strengthening research in new variety seeds, and encouraging greater use of organic and bio-fertilizers. Efforts to expand the disbursement of directed bank credit to agriculture, which nearly doubled in the wake of the floods in $1998 / 99$, are also being intensified. The target for total disbursement of agricultural credit through the banking system has been set at Tk 33,3 billion for 1999/2000, an increase of 10.8 percent from the already elevated level of $1998 / 99$.

\section{Manufacturing}

12. Production in both large-scale (particularly garments, textiles, fertilizer, and cement) and medium-scale manufacturing industries, which had reached a peak in February 1998, subsequently followed a declining growth trend and was basically stagnant over the first three quarters of 1998/99. While there was a modest pick-up of activity thereafter, its rate of growth remained sluggish. Output of ready-made garments (RMG), in particular, a major export commodity, performed poorly over much of the period, following several years of strong growth. Indigenous raw material-based industries, such as jute, fertilizer, sugar, tea, and cement, have also not performed well, while production of small and cottage industries was especially affected by the floods. Overall, manufacturing production rose by less than 2 percent in 1998/99, compared with a growth rate of more than 9 percent in 1997/98 and an average growth rate of more than $7 \frac{1}{2}$ percent in the preceding years of the decade (Table 8 ). The growth in the value added by small-scale industries, in particular, was virtually nil in1998/99.

13. The pervasive sluggishness in manufacturing activity points to deeply rooted problems in this sector. Apart from the effects of the floods and declining world commodity prices, an array of escalating infrastructural problems, including power shortages and transportation bottlenecks, together with a significant loss of external competitiveness, have been important contributing factors. The problems have been compounded by poor commercial and financial management, particularly in state-owned enterprises (SOEs) and commercial banks. This has given rise to large SOE losses despite recourse to explicit or implicit subsidization from the budget, and a massive accumulation of nonperforming bank 
loans. The probfems have often been exacerbated by trade union militancy. All these factors highlight the urgent need for a comprehensive reform strategy to help realize the potential of the industrial sector, including by improving the operation of SOEs, the financial sector, and the labor market, and by removing impediments to private investment, especially in the energy and transport sectors.

\section{In the RMG and related sectors, to reduce the heavy dependence on imported} inputs and increase the domestic value added of exports significantly above the current rate of about 30 percent, government policies have been aimed at promoting backward linkages with a view to attaining eventual self-sufficiency in tertiles. Access to adequate credit facilities for new investment and working capital, as well as reduced import duties for needed machinery and quantitative restrictions on textile imports, are part of this policy strategy. However, an efficient development of these backward linkages can be achieved only if progress is made with the overall structural reform effort, particularly to provide an environment conducive to viable private investment in these sectors and to eliminate trade restrictions that result in struggling of textile products from neighboring countries.

\section{Construction and Mining}

15. Construction activity, which had been slack in the early months of 1998/99, picked up strongly as various housing and infrastructural reconstruetion projects were undertaken following the floods. The expansion was especially pronounced in the public sector, where major repair and maintenance works for roads and bridges and other infrastructural projects were undertaken. Overall, output in the construction sector is estimated to have risen by 8.1 percent in 1998/99. Output in mining and quarrying, which was adversely affected by the floods, registered only modest growth for the year as a whole.

\section{Power}

16. The output of the power sector is estimated to have picked up significantly in 1998/99, reflecting the coming on stream of three new barge-mounted power units (see below) and a continuing expansion of gas output (Table 9). However, these increases have proved insufficient to meet the economy's increasing demand for energy. As a result, significant shortages of natural gas and electricity have persisted, with an important adverse impact on production and investment in other sectors, especially in manufacturing and services.

\section{To alleviate these shortages, the government has taken important steps to} encourage private sector involvement in the power and energy sectors. The Private Sector Power Generation Policy provides for various fiscal incentives to attract private investment. Following the government's decision in 1996 to seek proposals from the international private sector for independent power producer (IPP) plants, competitive bids have been solicited for four fast-track barge-mounted plants. The first of these commenced operations in October 1998, and two more were commissioned in May and June 1999. In addition, the government has put up for bid contracts for two large capacity gas-fired 
combined cycle plants and a gas turbine plant. In the energy sector, while private sector participation has been hampered by a lack of transparency in bidding and selection procedures, a number of Production Sharing Contracts (PSCs) for gas exploration and development are now in full operation and/or are about to be offered for a second round of bidding.

18. As of June 1999, cumulative past production and remaining recoverable reserves of gas were estimated officially at 3.574 trillion cubic feet and 10.216 trillion cubic feet, respectively. Beyond this, proven reserves are estimated privately at an additional 3 trillion cubic feet, with much larger gas resources considered highly probable. At the present rate of daily consumption, the remaining recoverable reserves, based on official estimates, are projected to meet domestic demand for about 30 years. However, if the demand for gas increases at an annual average rate of 7 percent, it is estimated that the present recoverable reserves would be exhausted by $2012 / 13$. The government has stated that, if substantial new reserves are proven in the near future, it might take steps to increase gas utilization; however, it would consider exporting gas only after meeting the country's long-term gas demand.

\section{Services}

19. The services sector--which comprises trade, hotels and restaurants, transport, housing, banking, insurance, and professional services-was only marginally affected by the floods. Growth in the services sector is estimated to have been broadly maintained in 1998/99 at 4.3 percent, with the depressing effect of the floods offset by the boost to the trade services sector from the growth in agricultural output.

\section{Prices, Wages and Employment}

\section{Prices}

20. Inflation rose from an average of 7 percent in 1997/98 to 9 percent in 1998/99, but it declined rapidly as the flood-induced surge in food prices began to be reversed. On a year-on-year basis, inflation reached a peak of 12.7 percent in December 1998 in the face of intensifying food supply constraints, but eased back to 7.7 percent by June 1999 . The year-on-year rate of inflation remained on a steadily declining trend in subsequent months and it had fallen to $31 / 2$ percent by October 1999 . Food inflation, which peaked at 17.6 percent in December 1998, had declined to 10.6 percent by June 1999 , falling further to 4 percent as of October 1999. While the drop in food inflation initially reflected the impact of the extensive food assistance in the immediate post-flood period, the record boto rice crop was apparently an important contributing factor in the closing months of 1998/99. Nonfood inflation, responding to the overall weakness in economic activity in the nonagricultural sector, fell steadily from a peak of 7.6 percent in September 1997 to 3.2 percent by June 1999 , and declined further to 2.5 percent in October 1999, its lowest rate in many years. However, to the extent that this decline was attributable to the restraining effects on prices stemming from the recent appreciation of the real effective exchange rate, it is likely to have been partially reversed following the depreciation of the taka in November 1999 (see below). 
In addition, the government's relatively rigid policy on administered prices, especially on petroleum products, is likely to have helped keep inflation at an artificially low, albeit not sustainable, level during the second half of 1999 (Tables 10 and 11).

\section{Wages and Salaries}

21. A national pay scale applies for all employees of the central government and nationalized corporations, except defense and police officers and workers in stateowned manufacturing industries. During the 1990 s, two adjustments in national pay scales were introduced, one in 1991 and the other effective from July 1, 1997. While the wage adjustment in 1991 was introduced in one step, the 1997 compensation package increase was introduced in three phases over the years 1997/98-1999/2000. The 1997 national pay scale is comprised of 20 scales, within which all civil servants are accommodated, with the highest and lowest monthly scales fixed at Tk 15,000 and Tk 1,500, respectively, as against Tk 10,000 and Tk 900 in 1991.

22. The first phase of the 1997 civil service compensation increase, covering the period July 1, 1997-June 30, 1998, provided for 60 percent of the difference between the gross salary accruing under the 1991 pay scale and the gross salary receivable in terms of the revised 1997 pay scale. The remaining 40 percent was paid in phase two (July 1 , 1998-June 30, 1999). The final increase in the overall compensation package, which affected allowances for house rent, medical expenses, and other fringe benefits, was introduced in phase three (July 1, 1999-June 30, 2000). According to the 1998/99 budget statement, implementation of the 1997 pay scale entailed a budgetary cost of Tk 20.75 billion spread over three years, with Tk 8.88 billion payable in 1997/98, Tk 4.95 billion in 1998/99 and Tk 6.91 billion in $1999 / 2000$.

23. In response to pressing wage demands from labor unions, the government appointed a "Wages and Profuctivity Commission" in May 1998 to recommend an improved wage structure for public sector industrial workers and employees working at the factory level. The existing wage structure is in line with the recommendations of a similar Commission appointed in January 1992, which were implemented with retroactive effect to July 1, 1991. According to its terms of reference, the Commission would consider the cost of living, capacity to pay of the industrial concerns, and productivity of the workers in recommending changes in the wage structure and other benefits. The Commission, which commenced its activities in February 1999, is expected to submit its report shortly. Meanwhile, due to the delay in the submission of that report, and under pressure from the trade unions, the authorities have granted some interim benefits to the workers, which would be counted against the increases expected to be granted under the new wage scale. These are: a one time grant of Tk 1,000 and Tk 500, respectively, for the regular and casual workers in August 1999, and Tk 300 and Tk 150 per month for all regular and casual workers, respectively, effective July 1, 1999.

24. Apart from the above, the Minimum Wage Board, a permanent body under the Ministry of Labor and Manpower, has been recommending minimum wages for 
workers in various private sector industries since 1960. Until 1996, this Board has recommended minimum wages for 38 categories of industrial activities. Recently, the government has requested the Board to recommend revised minimum wages for the unskilled and juvenile workers in the private sector.

\section{Employment}

25. Employment statistics for Bangladesh are dated, the latest Labor Force Survey having been conducted in 1995/96 (Table 12). Aggregate employment increased in the first half of the 1990s at a somewhat faster pace than the population, and this trend is likely to have continued during the latter years of the decade. An increase in the participation rate, especially for women, accounts for this. The share of agriculture in total employment has declined, a trend that is likely to continue with further improvements in agricultural productivity and continuing rural-urban migration. The shift in the labor force to urban areas has been directed importantly to the service sectors, where trade, transport and communication services in particular have provided expanding employment opportunities. A striking development has been an apparent decline in the share of employment in the manufacturing sector between 1990/91 and 1995/96. Although the sharp expansion, until recently, of the garments industry has strongly increased its demand for labor, especially female labor, the lack of dynamism in much of the industrial sector, especially in the stateowned enterprises, has significantly inhibited productive employment opportunities. A key concern over coming years will be the need to absorb labor from the informal sector (principally the non-farm rural sector), partly through appropriate training and other facilities, into potentially more remunerative labor-intensive activities. Markedly higher economic growth rates and labor market flexibility will be a prerequisite for expanded job opportunities and reduced underemployment and poverty in Bangladesh.

\section{Ftscal Developments ${ }^{3}$}

\section{A. Central Government Finances}

\section{Developments in 1998/99}

26. The overall fiscal deficit (excluding grants) is estimated to have widened from 4.2 percent of GDP in 1997/98 to 5.1 percent of GDP in 1998/99 (Chart 2 and Table 13) While the deficit outturn exceeded the initial budget target by over $1 / 2$ percentage point of GDP, it was only slightly above the post-flood emergency assistance program target. Although revenues fell significantly short of the post-flood target, and there was a higherthan-projected pick-up in current expenditures, delays in the implementation of development expenditure programs helped restrain the overall impact on the deficit. With the pace of project-aid disbursements also slowing, net external financing remained at its 1997/98 level

${ }^{3}$ Prepared by Era Dabla-Norris. 
CHART 2. BANGLADESH

FISCAL DEVELOPMENTS
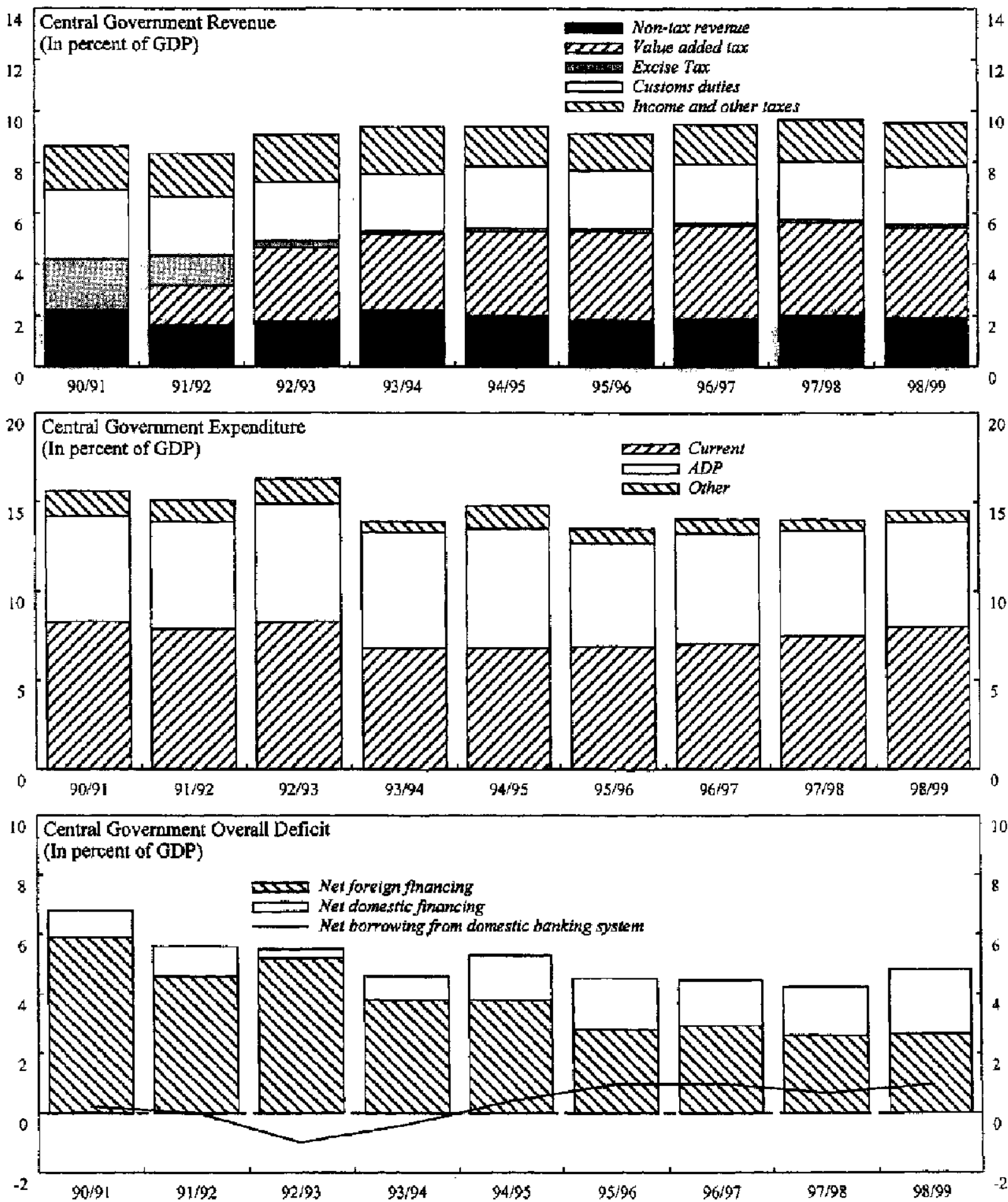

Sources: Bengladesh authorities; and staff estimates. 
of about $2 \frac{1 / 2}{2}$ percent of GDP, despite the surge in flood-related assistance. The government's domestic bortowing requirement rose to more than 2 percent of GDP in 1998/99 or about $1 / 2$ percentage point above the average level recorded in preceding years. As a result, government borrowing from the banking system, which had been targeted to remain at 0.7 percent under the emergency assistance program, rose to 1 percent of GDP in 1998/99.

\section{The revenue ratio edged down to 9.5 percent in $1998 / 99$, which was nearly} $1 / 2$ percentage point below the post-flood revenue target, notwithstanding the revenue measures adopted in October 1998 (Table 14). The tax ratio, at 7.6 percent of GDP, remained one of the lowest in the world, including among countries at Bangladesh's level of development. Shortfalls in tax revenue relative to the original budget target reflected the poor performance of VAT and customs duties following flood-related disruptions in commercial imports and industrial activities. Domestic VAT receipts, however, were in line with the budget target due to efforts to intensify tax collections in the second half of the fiscal year and higher-than-expected receipts from the construction and service sectors. The strong performance of income tax receipts was largely attributable to measures introduced in the $1998 / 99$ budget, including an expansion of the withholding tax, and making deduction at source the final settlement of liability in many cases. Nontax revenues were depressed by the lower-than-targeted dividends from public enterprises, including lower profits remitted by the state-owned telecommunications company.

\section{Total expenditure rose to $141 / 2$ percent of GDP in 1998/99 or more than}

$1 / 2$ percentage point of GDP above the previous year's level. While overall spending was in line with the initial budget target-and well within the post-flood target-this reflected a significant overrun on current expenditure which was offset by implementation delays in the Annual Development Program (ADP) (Tables 15 and 16). Current expenditure increased from 7 $\frac{1}{2}$ percent of GDP in $1997 / 98$ to 8.0 percent of GDP in $1998 / 99$, well above the postflood target, reflecting an unbudgeted 10 percent increase in pay and allowances and largerthan-anticipated domestic interest payments. Subsidies and current transfers also increased sharply due to higher pay support for nongovernment workers, large pension outlays, higherthan-budgeted transfers to the jute and textile sectors, and flood relief outlays. The food account deficit was significantly below the post-flood target as a bumper boro rice harvest in the second half of the fiscal year mitigated the need for higher food imports.

29. The composition of current expenditures has changed somewhat in recent years.

The largest component of current expenditures continues to be payment for goods and services, including pay and allowances to civil servants and operations and maintenance.

\footnotetext{
${ }^{4}$ Among the measures adopted in the context of the emergency flood assistance program were the rationalization of some tariffs, the imposition of a temporary $2 \frac{1 / 2}{2}$ percent customs duty surcharge, and the introduction of tax surcharges on interest income and on telecommunications services.
} 
However, the share of this component in total current expenditures declined from 65 percent in 1994/95 to about 50 percent in 1998/99, owing to a substantial compression of the nonwage element. By contrast, the shares of subsidies and current transfers and interest payments rose steadily over the same period, reflecting the rapid accumulation of domestic public debt, rising export subsidies, and the increasing drain on the budget from loss-making SOEs.

30. The financing of ADP expenditures, which comprise a significant portion of total expenditures, has also changed significantly in recent years, with domestically financed expenditures now accounting for a larger share of total ADP spending. In 1998/99, delays in project implementation and flood-induced disruptions helped restrain total ADP expenditure to about 6 percent of GDP or well within the post-flood emergency assistance program target. However, this reflected exclusively a shortfall in the foreign-financed portion of ADP, with the domestic portion slightly exceeding the budget target. Progress in improving the quality of $\mathrm{ADP}$ expenditures has remained slow in recent years owing to a combination of factors, including administrative weaknesses, the mid-year launching of projects approved outside normal budgetary mechanisms, and the failure to link budgetary support to project performance and evaluation.

\section{As regards the sectoral breakdown of ADP, agriculture (including rural} development and water resources) and transport continued to be accorded high priority, together accounting for 40 percent of total ADP spending in 1998/99. In the social sector, while the total share of education and health expenditures has remained broadly stable in recent years, the share of education expenditure, which had been on a declining trend since the mid-1990s, partially recovered, rising to 13.5 percent of total ADP spending in 1998/99. By contrast, the share of health, population and family planning expenditures, which had increased somewhat since the mid-1990s, declined from 9.6 percent of ADP spending in 1997/98 to 8.2 percent in 1998/99 as a result of delays in launching new programs. In relation to GDP, health and education expenditures have averaged 1 percent and 2.2 percent, respectively, over the $1995 / 96-1998 / 99$ period.

\section{The 1999/2000 Budget}

\section{The $1999 / 2000$ budget envisages a reduction in the overall deficit to 4.6 percent} of GDP, somewhat higher than the pre-nood ratio recorded in 1997/98. Total revenue is budgeted to increase by almost 1 percentage point in relation to GDP. Despite revenue losses likely to result from import tariff reductions and other tax telief measures, tax revenues are budgeted to increase with the help of improvements in tax and customs administration, an expansion of tax withholding, and a broadening of the base for the VAT (Box 1). Nontax revenues are also budgeted to increase substantially, on account of higher dividends and profit transfers from nonfinancial SOEs, a recovery in telecommunications profits associated with the installation of new telephone lines, and growth in interest income.

33. Total expenditure is budgeted to expand further to about 15 percent of GDP in 1999/2000. While total current expenditures are slated to decline in relation to GDP from 


\section{Box 1. Bangladesh: Tax Measures in the 1999/2000 Budget}

The 1999/2000 budget included a number of revenue measures to strtamline the tax and tariff structures, extend the VAT net, and strengthen tax and customs administration. The highlights of these measures are as follows.

\section{Income Tax}

- Perșonal income tax rates were nestructured and the general basic exemption limit raised from Tk 60,000 to Tk 75,000.

- The exemption on interest earnings from high yielding government savings certificates was eliminated and the base of the withholding tax expanded.

- A presuraptive tax on automobiles was introduced and existing rates on trucks and lorries increased.

- The 0.25 percent tax at source on exports was eliminated.

\section{Customs duties}

- The tariff structure has been simplified and the top rate (including a 2.5-percent import duty surcharge) reduced from 42.5 percent to 40 percent.

- Customs duty was harmonized at the loper rates on commodities falling under the same H.S. Code.

- New exemptions to import tariffs were granted in a number of areas, and tariffs on raw materials and intermediate goods were reduced.

VAT, supplementary duties and excises

- The coverage of the VAT was extended to 31 new retail iterns and a few professional services.

- The electricity duty was replaced with VAT applied on a truncated basis.

- The exemption limit on the turnover tax was increased from Tk 1.5 million to Tk 2 million.

- A 2.5 percent supplementary duty was introduced on imported finished goods (without domestic substiturtes) subject to the top customs duty rate.

- A 10 percent supplementary duty on 272 items (subject to a customs duty rate of over 5 percent) is to be introduced on the date of introduction of mandatory pre-shipment inspection (PST).

\section{Tax and customs administration}

- Assessment procedures were simplified and measures were taken to improve accountability and organizational structure in customs administration.

- Introduction of a unique tax payer identification number (TIN) was announced.

- The establishment of a large taxpayer unit (LTU) was announced.

- Replacement of the voluncary PSI system by mandatory PSI was announced. 
their 1998/99 levels, subsidies and transfers are budgeted to remain significantly over their $1997 / 98$ levels and incorporate a wide range of subsidies to select industries, in particular, tthe export sector. ADP spending, which is budgeted to rise by about 0.7 percentage points of GDP in 1999/2000, is to be partly offset by limiting the growth of recurrent expenditures. The share of education spending in total ADP is budgeted to fall back towards its 1997/98 levels, while the previous year's decline in the share of outlays on health, population and family plarning is to be more than reversed.

34. Preliminary data point to a worse-than-budgeted outturn during the early part of 1999/2000, which could make it difficult to adhere to the full-year budget target in the absence of additional corrective measures. Delays in the implementation of the mandatory pre-shipment inspection system envisaged in the budget, combined with weak import VAT and customs duty collections in the first quarter of the fiscal year, raise doubts as to the feasibility of meeting the budget's ambitious full-year tax revenue target. Preliminary indications also point to a significant shortfall in nontax revenue, largely owing to lower-than-budgeted transfers from financially weak SOEs. On the expenditure side, larger-than-expected interest payments and the possibility of granting higher subsidies to SOEs for incipient wage increases (which would likely be applied retroactively), can be expected to result in an overnun in current expenditures. Moreover, a slow pace of foreign aid disbursements to date suggests that the trend toward increased recourse to domesticallyfinanced ADP spending is set to be extended. While data on actual expenditure outcomes are unavailable, a significant acceleration in the government's net recourse to bank credit in the early months of 1999/2000 suggests that expenditures may indeed be expanding more rapidly than targeted. According to preliminary data, net government borrowing from the banking system surged by more than Tk 20 billion during the first five months of 1999/2000 (JulyNovember 1999), exceeding the government's net bank borrowing during all of 1998/99. The government would need to make substantial net repayments on its net borrowing from the banking system in order to bring it back within the TK 15 billion target by the end of the fiscal year, as envisaged in the $1999 / 2000$ budget.

\section{B. Public Enterprises}

\section{The financial performance of the ailing $\mathrm{SOE}$ sector continued to deteriorate in} 1998/99. As growth in operating costs, including higher outlays on wages and salaries, outpaced the increase in revenues, the public enterprises' aggregate operating surplus to assets, which measures the return as a share of capital employed, fell by 0.5 percentage points from the already low level recorded in 1997/98, thus reverting to a negative number (Table 18). With gross fixed capital formation recording a large increase, net borrowing by the nonfinancial SOEs, excluding equity injections from the budget but including the continuing accumulation of arrears, surged from Tk 12.5 billion $(0.7$ percent of GDP) in $1997 / 98$ to Tk 33.5 billion (1.6 percent of GDP) in 1998/99. The consolidated losses of nonfinancial SOEs rose from Tk 4.9 billion in 1997/98 to Tk 8.1 billion in 1998/99, with the petroleum and gas monopolies being among the few enterprises that remitted profits to the central government (Table 19). The resultant delays in servicing SOE debts to the government and banks, the inability to pay dividends as envisaged in the budget, and the 
higher subsidies obtained to finance the SOEs' operations have placed a growing burden on the central government's accounts. ${ }^{5}$

36. The lack of progress with respect to the restructaring and privatization of public enterprises reflects deep-seated inefficiencies and governance problems, including political interference, lack of managerial accountability, and soft budget constraints. These factors have served to perpetuate the poor performance of enterprises in the jute, textile, power, and fertilizer sectors. Delays in the needed adjustment of administered prices, in particular, have seriously undermined the profit potential of Petrobangla and the Bangladesh Petroleum Corporation. ${ }^{6}$ Vested interests, technical difficulties with respect to the valuation of the enterprises' assets, and trade union militancy have been important factors thwarting efforts toward privatization. Of the 44 enterprises identified for privatization during $1998 / 99$ by the Privatization Board, only a handfil have so far been privatized.

37. The government's reform agenda in the SOE sector for 1999/2000 appears to be limited to the closure of three textile mills and one steel mill. While the 1999/2000 budget speech acknowledged the serious financial difficulties of some SOEs, including an increasing stock of overdue loans to the banking system (especially by the jute sector), the only envisaged government actions are to begin to repay some of these loans to banks and to provide additional government loans to loss-making SOEs. The budget included no measures to introduce hard budget constraints on SOEs nor did it propose any steps to further rationalize natural gas, electricity, petroleum and fertilizer prices. While the Privatization Board has identified 50 enterprises for privatization in 1999/2000, progress to date with enactment of the Privatization Law has been slow and the government has yet to build the political consensus required to adopt a concrete program of SOE reform and privatization

38. In the energy and power sectors, the government's reform efforts have focused on restoring the profitability of existing operations and encouraging private investment in power generation by IPPs. However, despite heavy subsidization of natural gas prices - especially for the fertilizer and power sectors - these sectors continue to incur substantial losses. In the power sector, which continues to suffer from serious billing and collection problems, electricity tariffs were recently raised on average by 4 percent in two installments (in July 1998 and September 1999). However, little progress has been made to restructure this sector through the needed unbundling of the generation, transmission, and distribution of power.

${ }^{5}$ Total SOE debt stood at Tk 470 biltion or 26.8 percent of GDP as of June 1997, with debt on foreign loans owed to the government accounting for over 40 percent of the total.

${ }^{6}$ Petrobangla's profit increased from Tk 1.3 billion in $1997 / 98$ to Tk 1.8 billion in 1998/99 following a 15 percent hike in natural gas prices in December 1998. The adjustment in natural gas prices, however, was significantiy below that required to align prices with those prevailing in international markets. 


\section{MONETARY and Financial Sector DeVelopments?}

\section{A. Monetary Developments}

39. The indicative monetary program for $1998 / 99$, adopted in conjunction with the emergency flood assistance program in October 1998, envisaged an acceleration of broad money growth from 101/2 percent in 1997/1998 to 121/2 percent in 1998/99 (Table 20). This was projected to be adequate to allow for sufficient credit to the productive sectors, while also accommodating a modest acceleration in inflation without exerting pressure on gross official reserves. Consistent with these objectives, and in line with the postflood budget, bank credit to government was targeted to expand by 0.7 percent of GDP (Tk 15 billion) in 1998/99. This was expected to leave enough room for private sector credit (including flood-related credit to agriculture) to expand by 14.8 percent in 1998/99.

40. In the event, monetary policy tumed out to be somewhat more expansionary than programmed in 1998/99. Broad money accelerated at a slightly faster rate than had been programmed, fueled by a rapid growth in the net domestic assets of Bangladesh Bank, which led, in turn, to a sustained expansion of reserve money (Chart 3 and Table 21). With Bangladesh Bank accounting for about half of the increase in total net bank credit to government, the overnu in the government's bank borrowing was a principal factor underlying the monetary expansion. The other main factor underpinning reserve money creation was the sustained growth in Bangladesh Bank credit to specialized credit institutions. While the emergency assistance program envisaged that exceptional credit from Bangladesh Bank (up to Tk 9 billion), which was to finance the rescheduling of bank loans of small holders in agriculture and industry and Grameen Bank, was to be provided on a strictly temporary basis of 6-12 months, the repayment record on these loans was worse than anticipated. In all, while credit to the private sector remained well within the official target, the growth in total net domestic assets of the banking system, at 15.4 percent, overshot the target by some 2 percentage points. As a result, net foreign assets of the monetary system failed to improve as programmed in 1998/99, and declined instead.

41. The liquidity position of the deposit money banks strengthened in the course of 1998/99. Excess liquid assets of the deposit banks rose from the equivalent of about 4 percent of deposits in June 1998 to 6 percent of deposits as of June 1999 (Table 22). It would appear

\footnotetext{
${ }^{7}$ Prepared by Birgir Amason.

${ }^{8}$ The reserve money multiplier fluctuated in a relatively narrow range in 1997/98-1998/99. Throughout that period, most commercial banks were subject to a statutory liquidity requirement (SLR) of 20 percent, of which 5 percent had to be held as a cash reserve (CRR); for the four Islamic banks, the SLR has been 10 percent. The specialized banks have been subject to the CRR only.
} 
CHART 3. BANGLADESH

MONETARY DEVELOPMENTS

January 1995 - September 1999
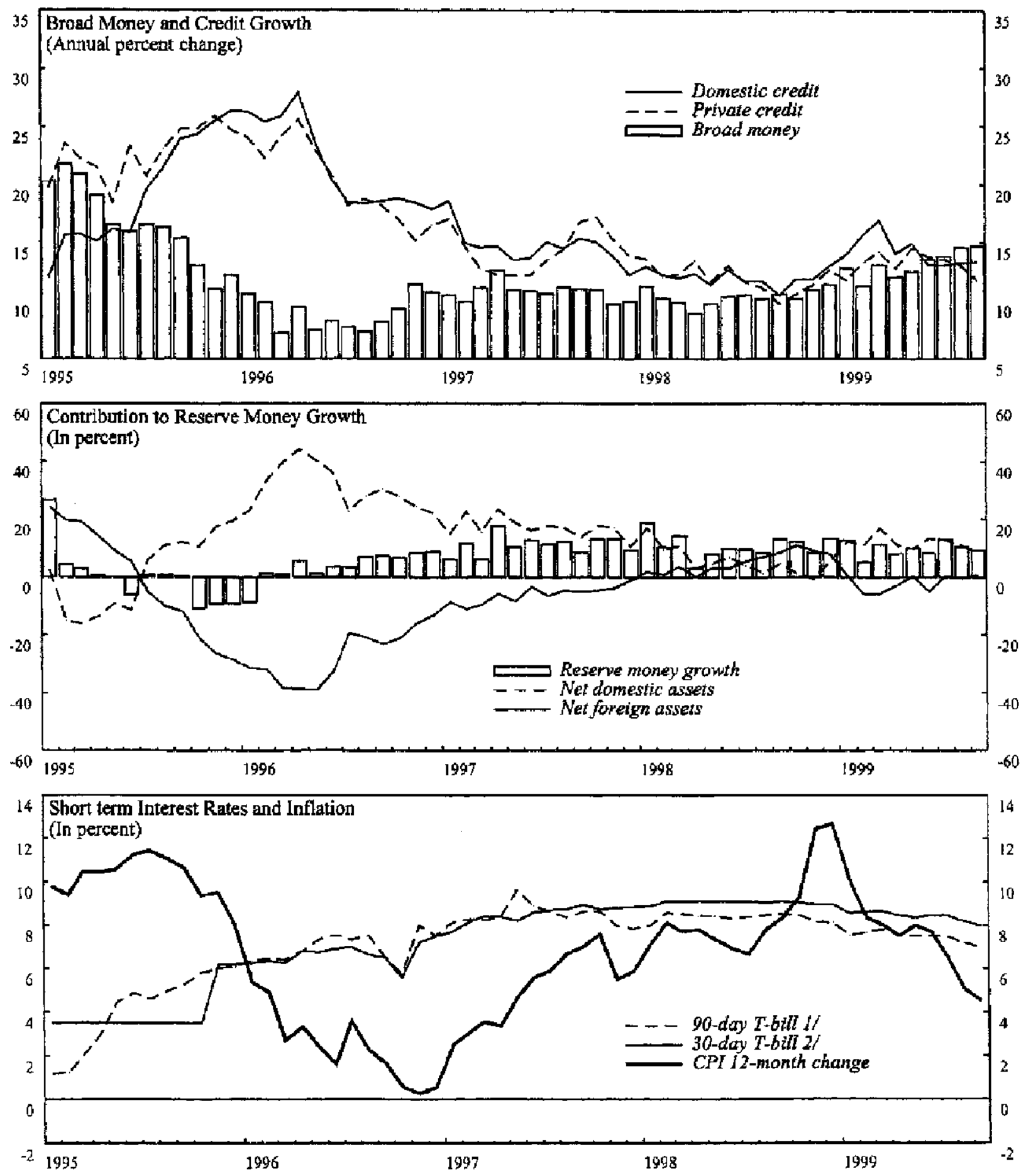

Sources: Bangladesh Bank; and staff estimates.

/ Bangladesh Bank bill rates till October 1998.

2/ Bangladesh Bank bill rates till October 1998. 
that this strengthened liquidity position may, to some extent, reflect more prudent practices by commercial banks in the extension of credit to less-than-creditworthy borrowers.

\section{During 1998/99, there was a sustained decline in the yields on treasury bills at} auction. ${ }^{9}$ This decline was more pronounced on the long end than the short end of the term spectrum (a flattening of the yield curve), suggesting that lowered inflation expectations may have played a role, in addition to the improved liquidity position of the banking system. The yields on one- and two-month treasury bills fell by about $1 / 2-1$ percentage point in 1998/1999, to $71 / 2-81 / 2$ percent in June 1999 (Table 23). By comparison, the yields on one- and two-year bills fell by 1.3 percentage points and 2.5 percentage points, respectively. Deposit and lending rates of deposit money banks, by contrast, do not appear to have changed much in the course of 1998/99. These developments point to some sluggishness in the responsiveness of commercial bank interest rates to money market conditions, which is due largely to the deepseated inefficiencies and structural problems in the banking system.

43. Monetary and credit conditions continued to be eased during the early months of 1999/2000. As already noted, the weakening of the public finances led to an accelerating expansion of net bank credit to government, including from Bangladesh Bank, during the first five months of 1999/2000. In August 1999, Bangladesh Bank lowered its bank rate from 8 percent to 7 percent. The effects of the continuing increase in excess liquidity in the banking system were further amplified in October by a reduction in the CRR by 1 percentage point, which was aimed at easing pressures on commercial bank profit margins and facilitating a narrowing of interest rate spreads. Thus, short-term treasury bill rates fell by another $1 \frac{1}{2}-2$ percentage points during the first half of $1999 / 2000$, to a level of $6-61 / 2$ percent by mid-December. Steps were also taken to spur the growth of credit to the private sector. Aside from the already-noted plans to further expand the disbursement of directed credit to agriculture, which is targeted to increase by 11 percent in 1999/2000, the government launched a new scheme to encourage term-lending by commercial banks, with funding to be secured through the issuance abroad of foreign-currency, government-guaranteed certificates of deposit by the nationalized commercial banks (NCBs). While the growth in credit to the private sector did not show any sign of picking up during the first four months of 1999/2000, this was probably attributable, as already noted, to intensified efforts to improve the quality of bank assets, including by halting lending to defaulters. The year-on-year rate of growth of broad money accelerated to nearly 16 percent in October 1999.

\footnotetext{
${ }^{9}$ As part of a gradual shift since the mid-1980s away from a highly centralized system of monetary management to a more liberalized system, interest rates have been generally liberalized and indirect monetary instruments have been introduced. Treasury bills have been auctioned on a bi-weekly basis since late 1995 . Floors on deposit rates were lifted in early 1997 and, after ceilings on interest rates to agriculture and small and cottage industries were lifted in July 1999, loan rate ceilings are only in effect for export loans.
} 


\section{B. Banking Sector Developments ${ }^{10}$}

44. The banking sector in Bangladesh has been in distress for more than a decade. ${ }^{11}$ It has been estimated that the cost to the government of rehabilitating the banking system-through the assumption of bad SOE loans, the scaling back of redundant NCB staff, and the recapitalization of the $\mathrm{NCB}$ — would be at least on the order of 10 percent of GDP, depending on how quickly and decisjvely the rehabilitation effort can be launched. ${ }^{12}$

\section{The government has taken important steps to improve the regulatory and legal} environment for banks, but bolder actions will be needed to remove the remaining weaknesses in the effectiveness of central bank supervision and in the governance of publicly owned banks. Prudential regulation and supervision have been strengthened over the last five years under a program to progressively move towards the application of international standards of loan classification and provisioning. Following the last phase of that program, which took effect in January 1999, these standards have been considerably tightened (Box 2). Bangladesh Bank has also taken steps to discipline private bank directors and managers who were in default on their own loan obligations, and the courts have recently upheld these actions. This, together with ongoing efforts to improve the operation of the legal system, appears to have strengthened many borrowers' incentives to settle overdue loans from private domestic banks (PDBs). Thus, the incidence of nonperforming loans in the PDBs fell steadily from more than 40 percent in the mid-1990s to about 30 percent as of June 1999 (Table 29). By contrast, the share of classified loans in the NCBs, which have much more limited managerial autonomy and whose lending operations may be subject to political interference, rose from 32 percent to 47 percent over the same period, while the share of classified loans in the state-owned specialized banks has risen to 68 percent.

46. The serious challenges for both private and state-owned domestic banks are highlighted by the large remaining gaps with respect to capital adequacy and provisioning requirements. While the aggregate capital adequacy ratio of PDBs had risen above the 8-percent minimum requirement by June 1999, it was more than 30 percent short

\footnotetext{
${ }^{10}$ Bangladesh's banking system problems were analyzed thoroughly in Chapter III in Selected Issues (SM/98/241), October 6, 1998. This section updates some of the information presented in that chapter.
}

${ }^{11}$ The banking system dominates the financial sector in Bangladesh, accounting for about 97 percent of the market in terms of assets (Table 26). Among commercial banks (not including the specialized banks), four NCBs have consistently accounted for over 60 percent of assets since the mid-1990s, while private domestic banks (PDBs) accounted for about 32 percent, and foreign banks for the remaining 6-7 percent. The total assets of the specialized banks are equivalent to about a fifth of those of the commercial banks.

${ }^{12}$ See chapter I in Selected Issues (SM/98/241), October 6, 1998. 
of that requirement for the NCBs. The NCBs' total shortfall in capital and provisions actually doubled from about Tk 22 billion in December 1996 to Tk 44 billion as of June 1999 (Tables 30 and 31). For the PDBs and the specialized banks, that shortfall fell marginally in nominal terms over the same period. However, the shortfall in provisioning remained well in excess of actual capital for all four NCBs - as well as for a number of PDBs-thus rendering these institutions technically insolvent.

\section{Box 2. Bangladesh: Classification and Provisioning Rules}

Bangladesh Bank's loan classification and loss provisioning nules and criteria have gradually been tightened in recent years to bring them into line with international standards. The latest change in regulations, issued on December 12, 1998, took effect on January 1, 1999.

Beginning in 1997, continuous and demand loans were classified as "substandard" when overdue for 9-24 months, "doubtful" if overdue for 24-36 months, and "bad" if overdue for more than 36 months. Under the existing regulations in effect since January 1999, the corresponding thresholds have been reduced to 3-6 months, 6-12 months, and more than 12 months, respectively. Term loans with a maturity of less than five years are classified as "substandard" if overdue 6-12 months, as "doubtful" if overdue 12-18 months, and "bad" if overdue more than 18 months. For term loans with maturities of more than five years, the corresponding thresholds are "substandard" 12-18 months, "doubtful" 18-24 months, and more than 24 months "bad".

The only change in provisioning rules introduced in January 1999 was an increase in the required provisioning for "substandard" loans from 10 percent to 20 percent. Otherwise the provisioning requirements remained the same: 1 percent for unclassified loans, 50 percent for "doubtful" loans and 100 percent for "bad" loans.

With these changes, loan classification and provisioning rules in Bangladesh have been brought to a considerable degree into line with best international practice. The main remaining difference is that short-term agricultural loans and micro-credit are subject to substantially less rigorous classification criteria: "substandard" if overdue 12-36 months, "doubtful" if overdue 36-60 months, and bad if overdue more than 60 months. For these types of loans, the provisioning requirements are also different: 5 percent for all loans not classified as "bad" (including unclassified loans) and 100 percent for "bad" loans.

\section{Significant changes in bank legislation, together with greater political} commitment to reform, will be required to address these problems. In particular, Bangladesh Bank's effective autonomy and authority in the conduct of bank supervision will need to be greatly enhanced to enable it to deal decisively with poorly governed private as well as public banks. In addition, decisive reforms will need to be introduced in NCBs and specialized banks, to enhance managerial autonomy, improve the process of selecting and 
appointing managers, and limit the role of social and political considerations in lending operations.

\section{Capital Market Developments}

48. The equity market in Bangladesh has yet to recover from the bursting of a stock price bubble in 1996/97. The Dhaka Stock Exchange (DSE) all-share price index continued to fall rapidly during 1997/98, and it remained on a broadly declining trend thereafter, albeit at a slowing pace. As of end-1999, the DSE index had fallen below 500, less than half the end-June 1997 level and some 10 percent down from June 1999. The sustained weakening of stock prices reflects in part the poor performance of many enterprises, and the impact of political unrest and the uncertain business environment, as well as a lack of investor confidence stemming from serious governance problems (including insider trading). To address some of these problems, the government has taken steps to improve settlement procedures and enhance the supervisory powers of the Securities and Exchange Commission (SEC). However, much more remains to be done, and the AsDB is involved with the authorities in a long-range project aimed at fiuther strengthening market regulation and supervision, establishing a more modern market infrastructure, increasing the supply of securities, and developing institutional sources of capital.

\section{EXTERNAL SECTOR DEVELOPMENTS ${ }^{13}$}

\section{A. Exports, Imports, and the Current Account}

49. External sector developments have been greatly affected by the massive floods in the third quarter of 1998 and the apparent loss of competitiveness of the export sector in the wake of the Asian crisis. The current account deficit (including official current transfers) increased to almost 2 percent of GDP in 1998/99 from about $1 / 2$ percent in 1997/98, thereby breaking the improving trend of the previous two years (Chart 4 and Table 32). This was due primarily to a sharp slowdown in the export growth rate, coupled with the floodinduced surge in food imports. The preliminary external sector data for the early months of $1999 / 2000$ are difficult to interpret because of the floods, which heavily influenced the 1998/99 numbers. Exports now appear to have reverted to their 1997/98 levels, after having fallen sharply in the early months of 1998/99, while nonfood imports are picking up. However, with food imports falling sharply in the wake of the recent bumper crops, the pressure on the external accounts has so far remained subdued. Official reserves had leveled off at about $\$ 1.6$ billion or the equivalent of 2.2 months of imports as of end-1999.

${ }^{13}$ Prepared by Jens Dalsgaard. 
CHART 4. BANGLADESH

EXTERNAL SECTOR DEVELOPMENTS
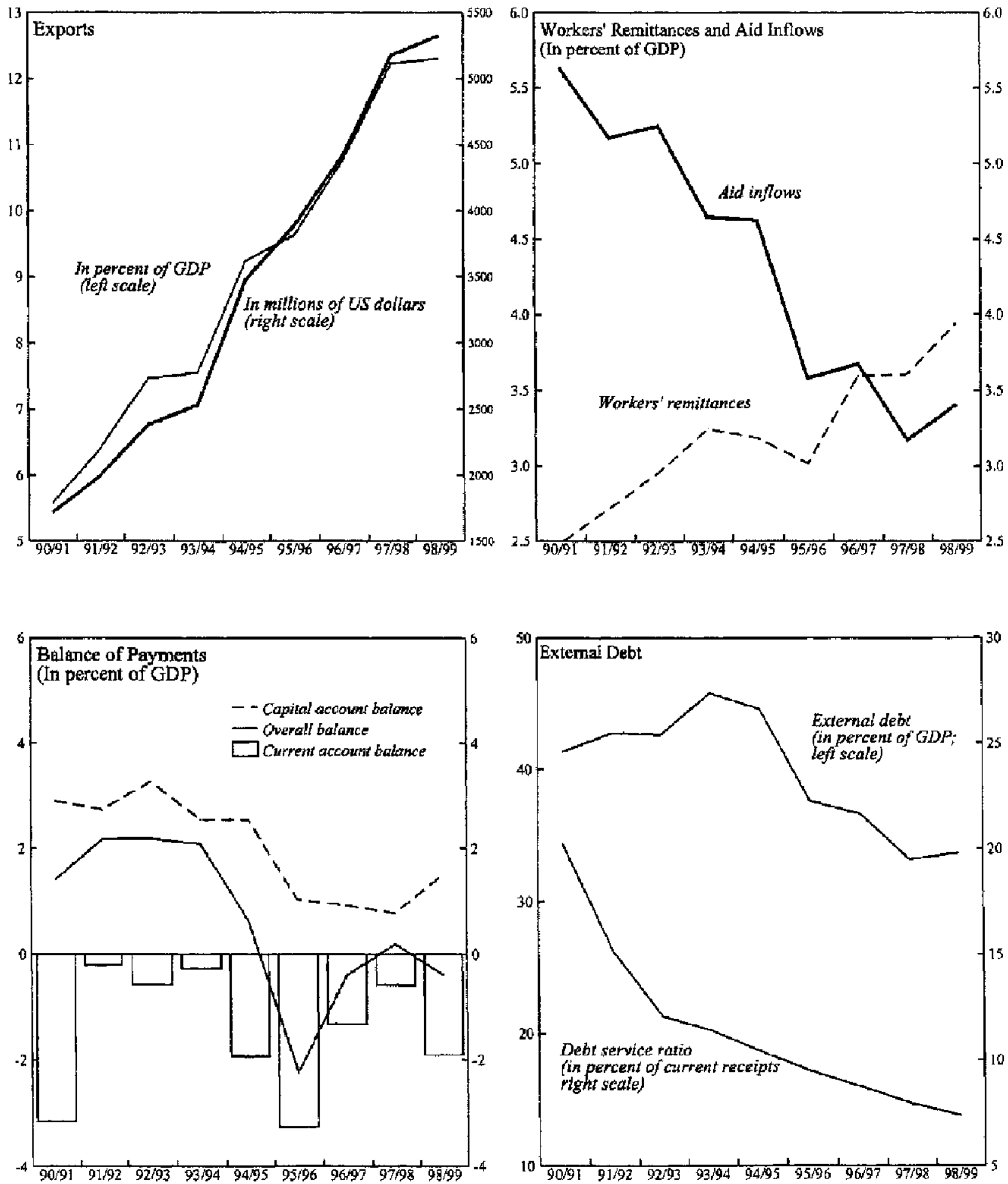

Sources: Bangladesh Bank; and staff estimates. 


\section{Exports}

50. The strong growth in export receipts, which had averaged about 20 percent annually during 1994/95-1997/98, came to a sudden end in 1998/99, when the growth rate dropped below 3 percent. The slowdown in export growth was broad-based, pointing to a significant loss of competitiveness following the sustained real effective appreciation of the taka (see below). Most importantly, the growth rate in exports of ready-made garments (RMG) and knitwear and hosiery protucts, which account for more than 75 percent of total exports, slowed from an average of more than 25 percent during 1994/95-1997/98 to only 6 percent in 1998/99 (Table 33). While hosiery and knitwear exports rebounded during the first four months of 1999/2000, RMG exports had barely increased from the depressed level recorded during the same period in 1998/99. Exports of other major sectors, including raw jute, tea, leather, and frozen shrimps and fish contracted significantly in 1998/99, reflecting the combined effects of declining world prices in these sectors and, in some cases, falling export volumes in the aftermath of the floods.

\section{Data on the geographical distribution of exports, which are only available} through 1997/98, reflect primarily the dynamism of Bangladesh's RMG sector up to that point. The main markets for this sector are in North America and Western Europe, which have in recent years accounted for close to 80 percent of total exports (Table 34). To some extent, the heavy concentration of exports in these markets, in which Bangladesh's access is protected by quotas or other privileges, may have served to shelter Bangladesh from the first-round effects of the East Asian crisis. At the same time, however, this concentration makes Bangladesh more vulnerable to exogenous chocks and other changes in the trade regime. ${ }^{14}$ In this context, the Bangladeshi authorities have recently initiated an export diversification program, supported by the World Bank.

\section{Imports}

52. Import growth is estimated to have jumped from an average annual rate of about 5 percent in 1996/97-1997/98 to about 11 percent in 1998/99. This increase mainly reflected the extraordinary need to import rice, wheat, edible oils, and other food items following the floods (Table 34). However, the increase in foodgrain imports was partially reversed after a successful boro crop in the spring of 1999 . With the notable exception of imports of capital goods, which are estimated to have increased by 11 percent following the continued flow of foreign direct investment into the energy sector, imports of most other

\footnotetext{
${ }^{14}$ Bangladesh benefits from preferential treatment with respect to exports of RMG products to the United States, Canada, and the European Union. These special privileges are to expire by end-2004 and, at that point, Bangladesh will have to compete on an equal footing with other countries in worid export markets.
} 
product categories remained broadly flat or decreased during 1998/99, reflecting the weakness in domestic investment and business activity. ${ }^{15}$

53. The geographical distribution of imports is rather diverse. The main countries of origin of Bangladesh's imports are India (15 percent), followed by Western Europe (13 percent), China (10 percent), Japan ( 9 percent), Korea ( 7 percent), North America (6 percent), and Hong Kong SAR (6 percent). ${ }^{16}$ The combined share of Asia's other emerging economies in Bangladesh's imports was about 10 percent in 1997/98.

54. Despite significant steps to liberalize the trade regime during the first half of the $1990 \mathrm{~s}$, the relative sixe of the external sector in Bamgladesh continues to be small in an international perspective, although it is about average in a regional context.

Bangladesh's total external trade reached about 31 percent of GDP in 1998/99, an increase of about 6 percentage points from 1994/95. By comparison, total trade in India, Pakistan, Nepal, and Sri Lanka is estimated at about 22 percent, 28 percent, 47 percent and 72 percent of GDP, respectively.

\section{The Current Account}

55. The impact of the increase in the trade deficit in 1998/99 was partially offset by an increase of about 20 percent in workers' remittances relative to the level in 1995/961997/98. Remittances from the Middle East (mainly Saudi Arabia, Kuwait and the United Arab Emirates), which is traditionally the largest outlet for Bangladesh expatriate labor, increased especially strongly, as did remittances from the United States and Japan (Table 36). ${ }^{17}$ Although remittances from Malaysia declined, other countries affected by the East Asian countries have been relatively minor sources of Bangladeshi emigrants' remittances.

56. While the share of workers' remittances in foreign exchange inflows has remained broadly constant in recent years, at a level of around 30 percent of export

\footnotetext{
${ }^{15}$ Staff estimates of capital goods imports in 1998/99 exceed the official preliminary estimates, reflecting an adjustment to account for under-recorded FDI-related imports.

${ }^{16}$ While India's share in total imports rose significantly during the 1990 s, the official data are likely to understate this share, as there is reportedly a substantial amount of unrecorded border trade. Because India's share in recorded exports has remained virtually flat at 1 percent, Bangladesh's large bilateral trade deficit vis-à-vis India is a politically sensitive issue, which is often used as an argument against further trade liberalization.

${ }^{17}$ The official estimate of workers' remittances is based entirely on information from the banking system. It is thus likely that significant transfers, which are made outside the official channels, are not included in the recorded statistics.
} 
earnings, current official transfers have decreased both in absolute and relative terms. Total official current grants fell from an annual average level of about $\$ 350$ million or more than 8 percent of exports in 1995/96-1996/97 to well below $\$ 300$ million or no more than 5 percent of exports in 1997/98-1998/99. The reduction in the level of official grants during $1998 / 99$ was particularly noteworthy, as it occurred in spite of the extra aid commitments secured following the floods. ${ }^{18}$ These developments may be a first sign of an increasing reluctance among donors to continue to channel large amounts of aid to Bangladesh in the face of the slow speed of economic reforms.

57. The service balance turned negative in $1998 / 99$ after two years of surplus (Table 37). While receipts remained broadly constant, payments related to the increasing number of energy projects are estimated to have jumped significantly, accounting for the change in the sign of the balance. ${ }^{19}$

\section{B. The Capital Account}

58. Capital account developments during 1994/95-1998/99 have been dominated by the continuing increase in FDI inflows. ${ }^{20}$ To a large degree this increase reflects the government's policy to attract foreign investment in the power generation and gas sectors. The disbursement of commodity loans and project aid (loans and capital grants) has remained broadly constant during 1995/96-1997/98, while the level of commodity loans rose sharply in 1998/99 following the floods (Tables 38 and 39).

59. The surge in FDI inflows into the power and gas sectors raises important issues with respect to longer-term external sustainability, as the inflows - so far-have not had any direct impact on export prospects. When the projects come on-stream they are expected to lead to an increase in net outflows of profits and dividends. This may put pressure on the current account and possibly on the budget, as many of the projects directly or indirectly carry a government guarantee. These risks will have to be taken into account and weighed against the benefits of the new FDI in easing production bottlenecks and consideration may need to be given to the possibility of promoting the export of natural gas.

${ }^{18}$ While the disbursement of total grants, including project-related capital grants, rose in 1998/99, this reflected mainly the increase in food-related aid (Table 38).

${ }^{19}$ According to staff estimates, service payments associated with past FDI are significantly higher than the preliminary official estimate.

${ }^{20}$ The FDI estimated by staff for $1998 / 99$ is significantly higher than the official preliminary estimate. The official estimate only partially covers FDI in the power sector, as the surveys conducted by the authorities suffer from a low response ratio. 
60. In spite of the increasing foreign debt stock, amortization payments have remained broadly constant in recent years, owing to the typically long grace and repayment periods on concessional debt. The item "other short term capital, including trade credits" in the balance of payments is defined by the authorities as the difference between the export estimates derived from payments statistics from the banking system and estimates based on information from the Export Promotion Bureau. In addition to trade credits, the item also covers capital flight and a number of known inconsistencies between the two sets of statistics. The authorities are working to eliminate these inconsistencies which include some double counting with respect to the treatment of trade transactions by Export Processing Zones (EPZs) and the treatment of some private amortization payments which are not channeled through the domestic banking system. "Other short-term capital" outflows have in recent years been larger than the total current account deficit, highlighting the remaining weaknesses in balance of payments statistics, which make it difficult to draw meaningful interpretations of the recent developments with any degree of accuracy.

61. The overall balance of payments turned negative in 1998/99, as the improvement in the capital account was not sufficient to reverse the worsening of the current account. Official reserves, therefore, declined by some $\$ 200$ million, to around $\$ 1.5$ billion at the end of the fiscal year, or the equivalent of 2.1 months of imports. With the need for food imports abating, reserves recovered somewhat in subsequent months, but the recovery was arrested as nonfood imports began to pick up, while exports remained weak. As of end-1999, official reserves had leveled off at about \$1.6 billion.

\section{Foreign Debt}

62. As a result of the strict capital account restrictions and the poor creditworthiness of most private enterprises, the private sector has in the past accumulated only limited foreign debt (Box 3 ). The foreign debt of Bangladesh is accordingly almost entirely public (or publicly guaranteed), with private debt estimated at around 5 percent of the total debt (Table 40). As of mid-1998, most of the existing debt stock carried long maturities and concessional interest rates, with more than two-thirds of the debt owed to multilateral institutions, including the World Bank and the Asian Development Bank, which accounted for 43 percent and 25 percent of the total debt, respectively. The bulk of the remaining debt was from official bilateral donors, mainly Japan (which accounted for 20 percent of total debt). As Bangladesh's past loans from the Fund under the Structural Adjustment Facility (SAF) and the Enhanced Structural Adjustment Facility (ESAF) have been progressively repaid, total debt to the Fund has decreased steadily both in absolute and relative terms over the last few years, and it now constitutes only about 2 percent of the total external debt.

\section{The external debt to GDP ratio has decreased steadily over the last few years} from more than 45 percent in 1993/94 to about 35 percent in 1998/99. This decrease has been a result of the steady growth of nominal GDP, coupled with the restrained pace of expansion of new external borrowing. Vahuation adjustments stemming from changes in the cross-exchange rates between the major currencies in which the bulk of the debt is 
denominated have also influenced Bangladesh's short-term debt dynamics in recent years. In particular, the depreciation of the Japanese yen relative to the U.S. dollar from mid-1997 to mid-1998 was a main factor behind the recorded decline in the total external debt measured in US dollars during this period. ${ }^{21}$ That decline was largely reversed in 1998/99, as the value of the yen recovered strongly. While the external debt of Bangladesh is moderate when measured in relation to GDP and, based on the current level and trends, the debt situation would be classified as sustainable, the low diversification of the Bangladeshi export sector and the country's almost complete dependence on official donor support make the external sector vulnetable to shocks. Debt servicing could accordingly become a problem under adverse circumstances, especially if the new opportunities available for FDI lead to less prudent external debt management policies in the period ahead.

\section{Bor 3. Bangladesh: External Debt Management}

Bangladesh has consistently remained current on its external debt obligations. The Economic Relations Department (ERD) under the Ministry of Finance has managed the external public debt of Bangladesh (both direct and publicly guaranteed) for a number of years within a framework of an internationally used debt management software provided by UNCTAD. However, the benefits of this software have not yet been fully reaped, as evidenced by the fact that the authorities have not yet been able to compile external debt statistics for end1998/99. Specifically, difficulties have been faced in entering debt to multilateral agencies into the database. Also the exchange of information on debt service payments with Bangladesh Bank needs to be streamlined. UNCTAD has initiated a project, with financial support from Norway, to address these problems.

Private external debt has not been monitored as closely as public debt in the past, largely because there was no significant amount of borrowing abroad by Bangladeshi enterprises. However, the ongoing boom in FDI and related inflows, together with the associated future servicing obligations, have recently highlighted the need to improve the availability and quality of data on private external debt. To that end, a monitoring system was recently established under the jurisdiction of the Board of Investment's Serutiny Committee, on which Bangladesh Bank is also represented. During the first nine months of 1999, that Committee approved $\$ 450$ million of new private sector external loans. Technical assistance to help improve the compilation and monitoring of private sector external debt is being provided by the Asian Development Bank.

${ }^{21}$ As of mid-1998, 36 percent of Bangladesh's external debt was denominated in SDRs, 34 percent was denominated in Japanese yen, 19 percent in US dollars, and 11 percent in other (mainly European) currencies. 


\section{The Erchange Rate System}

64. The taka is pegged to a basket of Bangladesh's major trading partners' currencies. The reference currency in day-to-day exchange rate management is the U.S. dollar. ${ }^{22}$ The Bangladeshi authorities have followed a policy of gradual, stepwise depreciations in the taka/U.S. dollar rate since mid-1995. The taka has accordingly been adjusted (devalued) more than 20 times since then. The typical rate of each adjustment has been on the order of 1-2 percent, with a frequency of about 2-3 devaluations per year. Duting 1999 , the taka was devalued by 2 percent vis-à-vis the U.S. dollar in July 1999 and by another 3 percent in November (Chart 5).

65. The real effective exchange rate (REER) of the taka, after having remained broadly stable in 1995-96, appreciated by more than 10 percent in 1997-98. This reflected the combined effects of the sharp depreciation of key competitor country currencies in the wake of the East Asian crisis, together with a pickup in the rate of inflation in Bangladesh relative to partner countries. The REER continued to appreciate through the middle of 1999. However, the rapid decline in domestic inflation, together with the two adjustments of the taka in July and November 1999 against the background of a sustained recovery of East Asian currencies, are estimated to have since helped more than reverse the appreciation in the REER that had occurred in the first half of 1999. Even so, as of end-1999, the REER remained at a level significantly above that prevailing in 1995-96.

66. Bangladesh accepted the obligations under Article VII, Sections 2, 3, and 4 in 1994 and has since then maintained full convertibility of the current account. In recent years, a number of bilateral payment arrangements have been phased out and none are now active.

67. Steps have also been taken to liberalize some capital account transactions in recent years. There are now no restrictions on the repatriation of proceeds from the sale of equity along with capital gains, profits and dividends from FDI (in the industrial sector), as long as the FDI has been registered with the Board of Investment (BOI). Similarly, inflows and disinvestment outflows of nonresidents' portfolio investments are freely permitted. However, non-residents are not allowed to buy money market instruments or treasury bills. Likewise, residents' portfolio investments abroad are not allowed, while outward direct investments are permitted only on a case-by-case basis. Short-term borrowing abroad by residents is only allowed for export purposes and requires a special permission by Bangladesh Bank, whereas long-term loans need approval by the BOI and can be only for

${ }^{22}$ Since 1996, Bangladesh Bank has been trading with authorized dealers in U.S. dollars only. Bangladesh Bank is not active in the foreign exchange forward market. 
CHART 5. BANGLADESH

EXCHANGE RATES AND OFFICIAL RESERVES

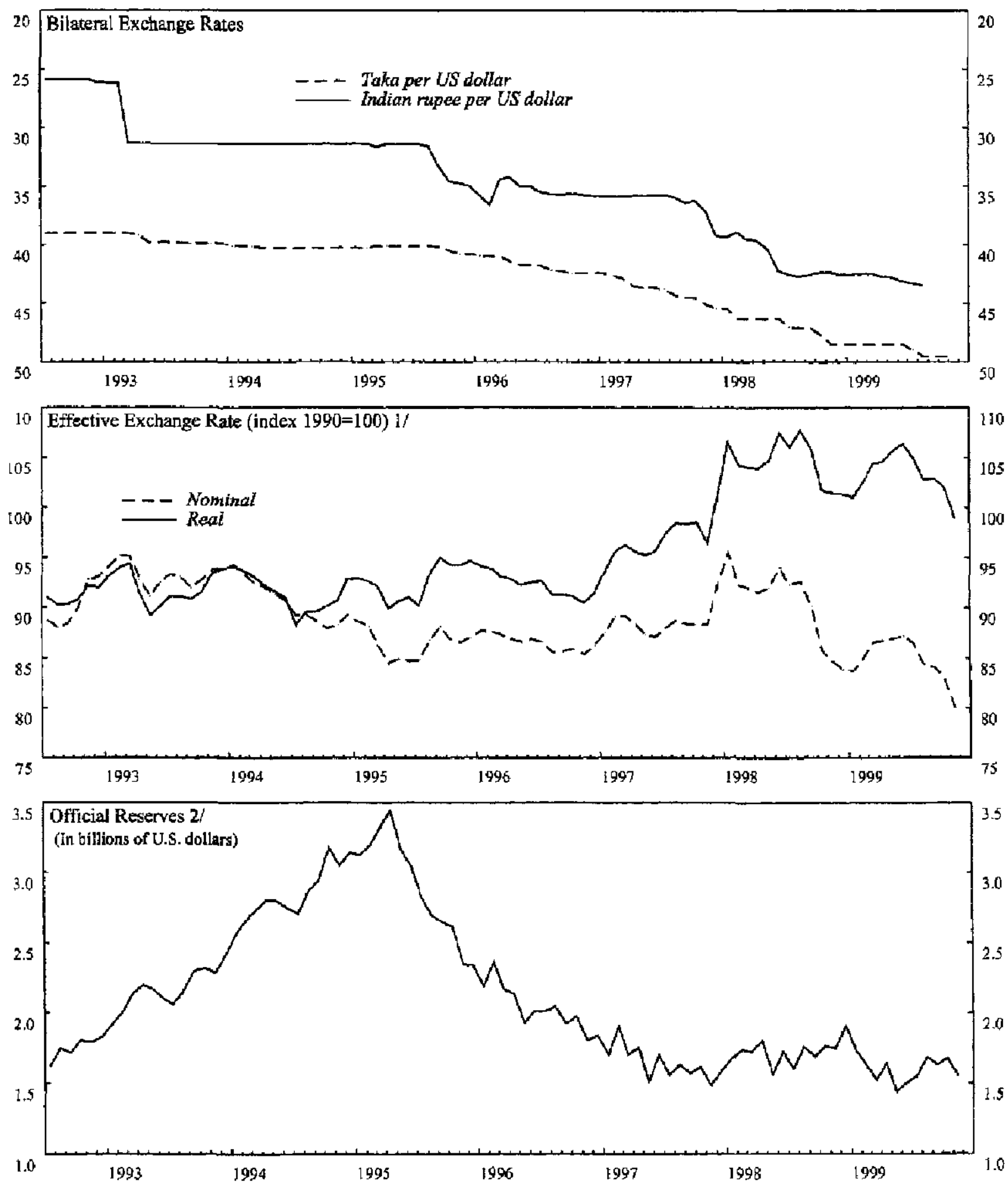

Sources: Data provided by the Bangladesh authorities; IMF, Information Notice System and International Financial Statistics.

1/ Downward movenent indicates depreciation.

2) Total of ficial reserves minus gold. 
industrial purposes. ${ }^{23}$ Also banks' borrowing abroad requires special prior approval by Bangladesh Bank. Finally, residents are required to repatriate export proceeds and other earnings from abroad.

\section{E. The Trade System}

68. The gradual liberalization of trade in Bangladesh, which was initiated in the mid-1980s, gained momentum under the Fund-supported ESAF program in the early 1990s, but progress has slowed down considerably since then. Compared to the starting point in the $1980 \mathrm{~s}$, the liberalization has been significant with the elimination of a large number of quantitative restrictions, and a substantial reduction in maximum and average tariff rates. ${ }^{24}$ However, the effective protection of import competing domestic industries still remains substantial due to low or zero tariff rates on raw materials and intermediate goods. According to World Bank estimates, the average nominal protection rate has remained 5-7 percentage points higher than the average unweighted tariff rate.

69. Under the $1999 / 2000$ budget, the structure of tariff rates has continued to be simplified, and the average tariff rate declined further, albeit in an uneven fashion. The maximum tariff rate was lowered from 40 percent in $1998 / 99$ to $371 / 2$ percent (excluding a $2 \frac{1}{2}$ percent infrastructure development surcharge) in 1999/2000, and the number of bands was reduced from $6\left(0,7 \frac{1}{2}, 15,25,30\right.$, and 40 percent $)$ to $5(0,5,15,25$, and $371 / 2$ percent). At the same time, the duty rate on commodities previously subject to a rate of 30 percent was lowered to 25 percent, while the rate on raw materials was reduced from $71 / 2$ to 5 percent. In addition, the infrastructure development surcharge was withdrawn for imports of some fertilizers, agricultural machinery, and key raw materials for the leather and textile industries. A number of new import duty exemptions were also granted under the 1999/2000 budget, including for imports of machinery and spare parts for the textile industry and capital equipment used in the tourism industry, and customs duties (previously set at 71/2 percent) were abolished for imported wood and certain types of machinery and pumps. By contrast, customs duties were raised on a number of goods, including raw silk yarn, certain polythenes, paper pulp, most books, retail packing and bulk import of bottled dry health drinks, and treated wood pole.

70. While tariff rates have remained on a broadly declining trend in recent years, tariff dispersion increased markedly. The average unweighted tariff rate (including the infrastructure development surcharge) is estimated to have fallen by about 4 percentage

${ }^{23}$ During 1999, some applications for short-term foreign loans were denied because the loans were intended for real estate purchases.

${ }^{24}$ The trade regime in the mid-1980s was extremely restrictive and was characterized by pervasive quantitative restrictions and prohibitively high import tariffs on many consumer goods. 
points, to a level of about 19 percent in 1999/2000. The weighted average tariff rate was estimated to be about $161 / 2$ percent as of $1998 / 99$. While this was significantly lower than the corresponding rate ( 24 percent) in 1991/92, it was only marginally lower than the rate reached in 1995/96 (17 percent). Moreover, reflecting the policy of systematically reducing tariff rates and/or granting new exemptions for raw materials and intermediate inputs for import-competing industries, tariff dispersion, after having fluctuated in a narrow range around 70 percent since 19991/92, is estimated to have risen to more than 80 percent in $1999 / 2000$.

\section{Nontariff trade barriers continue to include a number of import bans and} quantitative restrictions. Trade-related bans remain in effect on imports of chicken, salt, sugar (except in the case of imports by the state monopoly), cartons, petroleum products (by other than the state monopoly) and a number of textile items. A number of other import bans are in place for national security, environmental, health and religious reasons. These include bans on imports of firearms, narcotics, certain insecticides, and live pigs. An additional list of other products are subject to import quotas and require a special permit to import. These include cement, certain fertilizers, coal, and a number of textiles and knitted fabrics. All items that are not banned or subject to quantitative restrictions can be freely imported by registered importers.

\section{All registered importers have to pay an annual registration fee of Tk $500-5,000$} (\$10-100), depending on tornover and a permit fee of $2 \frac{13}{2}$ percent associated with Letter of Credit Authorizations (LCAs) above a threshold. Certain exemptions to these fees exist. Furthermore, an infrastructure development surcharge of $2 \frac{1}{2}$ percent was introduced in 1997/98. An additional temporary surcharge, which was introduced after the floods in 1998, has since been removed.

73. There are relatively fewer restrictions on exports, but some export bans do exist. Exports of a number of petroleum products are thus prohibited (except in the case of exports by foreign firms operating on production sharing contracts) as are exports of some agricultural/food products (oil, jute and sun hemp seeds, molasses, cane in whole form, wheat, rice bran, edible oil, onions, some saline water shrimps, and unfrozen and unprocessed prawns and shrimps). ${ }^{25}$ There is also a ban on exports of bamboo, wood logs, raw hides, and wet blue leather. Finally, nontrade-related bans are in effect on exports of firearms, fissionable material, rare archeological items, human skeletons, and materials

${ }^{25}$ The possibility of exporting natural gas is a politically controversial issue. Some arguments against exports of gas are based on projections of future domestic demand suggesting a very strong increase in domestic energy consumption, which could exhaust proven reserves in a relatively short period of time. However, another important factor may be that geographical considerations could imply that India would be the country most likely to show interest in importing large amounts of natural gas from Bangladesh, implying an increasing dependence of the Bangladeshi economy on developments in India. 
produced from human blood. Exports of a number of products require special permits. which are granted on a case-by-case basis. ${ }^{26}$

74. A number of EPZs have been established in recent years in Bangladesh. Imports to and exports from these zones are exempt from all tariffs and income taxes (for up to 10 years). The EPZs' share in foreign trade has increased during the last few years, rising from about 8 percent of total exports in 1996/97 to about 11 percent in 1998/99, and the EPZs' trade balance has shifted trom a deficit into a surplus. Fully export-oriented enterprises outside the EPZs are treated as if they were established in an EPZ and enjoy the same tax advantages.

75. An increasing number of direct and indirect export subsidies have been introduced in recent years. These include a 50 percent tax rebate on export earnings, duty drawback schemes, which over-compensate exporters, and a 10 percent export subsidy on the value of jute exports. Enterprises in the leather industry exporting at least 80 percent of their production are treated as fully export-oriented as are other industries exporting at least 80 percent of their production. Airfreight at subsidized rates is also made available to export industries. The 1999/2000 budget introduced a number of new export subsidies, including for the leather industry, exports of quilts and fresh and artificial flowers.

76. Based on the IMF's standardized index to measure trade restrictiveness, Bangladesh presently scores 6 on a scale of 1 to 10 , with 10 being the most restrictive. Both tariff rates and the extent of nontariff barriers are classified as "moderate" according to this classification. The present score is down from 10 in 1991/92, from 8 during 1992/93$1993 / 94$ and from 7 during 1995/96-1998/99. The index accordingly confurms that there has been a slowdown in the pace of trade liberalization since the mid-1990s. Furthermore, the trade restrictiveness index would probably be higher, if the asymmetric application of VAT and supplementary duties on imported and domestically produced goods and the LCA fee were taken into account. In a regional context, the trade restrictiveness index for Bangladesh remains relatively high. Thus, while it is lower than in India (10) and around the same as in Pakistan (7), it remains higher than in Malaysia (5), Korea (4), Indonesia (4), and Nepal (2).

\footnotetext{
${ }^{26}$ In order to comply with RMG import quotas of the United States and Canada, the quotas are distributed to domestic producers according to a fixed schedule.
} 
Table 1. Rangladesh: Gross Domestic Product at Current Prices, 1994/95-1998/99 1/

\begin{tabular}{|c|c|c|c|c|c|}
\hline & $1994 / 95$ & $1995 / 96$ & $1996 / 97$ & $1997 / 98$ & $\begin{array}{r}\text { Prov. } \\
1998199\end{array}$ \\
\hline & \multicolumn{5}{|c|}{ (In billinons of taka) } \\
\hline Agricnithurt and Fordstry & $\$ 07$ & 322 & 337 & 358 & 400 \\
\hline Crops and horticulture & 216 & 225 & 234 & 247 & 279 \\
\hline Animal finrring & 62 & 66 & 70 & 74 & 80 \\
\hline Forest and related services & 29 & 31 & 34 & 37 & 42 \\
\hline Fishing & 68 & 76 & 80 & 85 & 96 \\
\hline Mining and Quarrying & 16 & 18 & 19 & 20 & 21 \\
\hline Natural gas and orude petroleum & 9 & 10 & 10 & 10 & 10 \\
\hline Other mining and quarrying & 7 & 8 & 9 & 9 & 10 \\
\hline Menafifactaring & 253 & 277 & 303 & 351 & 347 \\
\hline large and medium scale & 186 & 204 & 219 & 253 & 247 \\
\hline Sonall scale & 67 & 74 & 84 & 99 & 100 \\
\hline Electricity, Gas and Water & 23 & 25 & 27 & 28 & 29 \\
\hline Electricity & 20 & 22 & 23 & 24 & 25 \\
\hline Gat & 2 & 2 & 3 & 3 & 3 \\
\hline Water & 1 & 1 & 1 & 1 & 1 \\
\hline Construntion & 104 & 117 & 126 & 142 & 158 \\
\hline Wholesale and Retril Trade & 221 & 242 & 259 & 284 & 307 \\
\hline Hotel and Restaurants & 9 & 10 & 10 & 11 & 13 \\
\hline Transport, Storage and Commmication & 162 & 172 & 184 & 195 & 206 \\
\hline Lend transport & 104 & 111 & 119 & $12 B$ & I37 \\
\hline Water transpout & 41 & 42 & 94 & 45 & 45 \\
\hline Air transport & 2 & 3 & 2 & 3 & 3 \\
\hline Suppent transport services, slorage & 5 & 5 & 5 & 5 & 6 \\
\hline Post and telocommunicafions & 10 & 11 & 14 & 14 & 15 \\
\hline Financial Intermediation & 21 & 24 & 26 & 28 & 31 \\
\hline Bank & 18 & 20 & 21 & 22 & 23 \\
\hline Instranice & 3 & 4 & 5 & 6 & 7 \\
\hline Others & $\cdots$ & $\cdots$ & $\therefore$ & $\cdots$ & 1 \\
\hline Real Estate, Renting and Business Activities & 131 & 151 & 163 & 176 & 195 \\
\hline Public Administration and Deferece & 33 & 36 & 40 & 44 & 50 \\
\hline Education & 23 & 25 & 27 & 32 & 35 \\
\hline Health and Social Worlos & 16 & 17 & 19 & 20 & 22 \\
\hline Community, Socialy and Persanal Services: & 124 & 136 & 146 & 162 & 174 \\
\hline GDP at current market price & 1,512 & 1,648 & 1,765 & 1,938 & 2,081 \\
\hline
\end{tabular}

Sourct: Bangladesh Bureau of Statipties

1/ Dats basod on $1989 / 90$ benohmark and prioes. 
Table 2. Bangladesh: Sectoral Growth Rates at Constant Prices, 1994/95-1998/99 1/

\begin{tabular}{|c|c|c|c|c|c|}
\hline & 1994/95 & $1995 / 96$ & 1996/97 & $1997 / 98$ & $\begin{array}{r}\text { Prav. } \\
1998 / 99\end{array}$ \\
\hline & \multicolumn{5}{|c|}{ (Amnual percent chatuse) } \\
\hline Agriculure and Forestry & -1.6 & 2.6 & 5.7 & 1.9 & 2.8 \\
\hline Crops and horticulture & -3.6 & 2.1 & 6.2 & 1.0 & 2.0 \\
\hline Amimal farming & 4.1 & 4.2 & 4.3 & 4.3 & 1.4 \\
\hline Forest and related services & 3.1 & 3.6 & 1.0 & 1.5 & 5.2 \\
\hline Fishing & 6.1 & 7.8 & 8.6 & 8.7 & 8.6 \\
\hline Mining and Quarying & 10.5 & 8.5 & 1.8 & 1.3 & 1.6 \\
\hline Natural gas and enude perroleum & 9.9 & 7.4 & -0.9 & 1.8 & -2.4 \\
\hline Other mining and quarrying & 11.7 & 10.2 & 6.7 & 3.2 & 8.5 \\
\hline Manufacturing & 10.4 & 6.4 & 6.2 & 9.2 & 1.6 \\
\hline Large and modium scale & 11.1 & 5.2 & 5.1 & 9.2 & 1.9 \\
\hline Small scale & 8.5 & 8.5 & 8.4 & 8.4 & 0.8 \\
\hline Electricity, Gas and Water & 5.2 & 6.4 & 3.2 & 2.7 & 6.3 \\
\hline Electricily & 5.2 & 6.3 & 2.0 & 0.8 & 6.8 \\
\hline Gas & 7.5 & 7.7 & 11.6 & 19.0 & 0.2 \\
\hline Water & 2.2 & 5.8 & 20.4 & 15.5 & 10.3 \\
\hline Construction & 10.8 & 7.9 & 5.4 & 8.0 & 8.1 \\
\hline Wholessale and Retail Trade & 14.3 & 4.8 & 6.2 & 5.4 & 5.0 \\
\hline Hotel and Restaurnents & 5.0 & 5.0 & 5.0 & 5.0 & 5.5 \\
\hline Transport, Storage and Communication & 5.2 & 4.9 & 3.6 & 1.3 & 6.2 \\
\hline Lend transport & 5.7 & 5.6 & 5.1 & 5.9 & 8.4 \\
\hline Water transport & 1.3 & 0.2 & 3.0 & 0.8 & -0.3 \\
\hline Air transpoit & $-8,5$ & 6.2 & -8.0 & 7.7 & 1.2 \\
\hline Support transport services, storage & 17.2 & 10.9 & -2.4 & 0.0 & 9.0 \\
\hline Post and telecommunications & 19.0 & 14.6 & 26.1 & 1.6 & 7.5 \\
\hline Finsuscial Intermediation & 5.1 & 4.9 & 5.2 & 5.0 & 5.1 \\
\hline Bank & 2.7 & $1 . t$ & 2.3 & 3.0 & 2.4 \\
\hline Insirance & 22.5 & 27.6 & 19.1 & 13.2 & 10.8 \\
\hline Real Estate, Remting and Business Activiti & 3.3 & 3.5 & 3.6 & 3.7 & 3.6 \\
\hline Public Administration and Defence & 4.5 & 3.1 & 5.2 & 5.6 & 5.1 \\
\hline Educetion & 4.9 & 3.4 & 1.7 & 11.6 & 4.7 \\
\hline Heailh and Social Works & 3.1 & 3.0 & 3.1 & 3.4 & 2.2 \\
\hline Cornmurity, Socialy and Personal Service & 3.0 & 3.0 & 3.0 & 3.0 & 3.1 \\
\hline GDP at constant matke price & 5.9 & 4.6 & 5.4 & 5.2 & 4.2 \\
\hline
\end{tabular}

Source: Bangladesh Bureau of Statistics.

1/ Date based on 1989/90 benchmark and prices. 
Table 3. Bangladesh: Gross Domestic Product by Expenditure at Current Prices, 1994/99-1998/99 1 /

\begin{tabular}{|c|c|c|c|c|c|}
\hline & $1994 / 95$ & $1995 \times 6$ & $1996 / 97$ & 1997198 & $\begin{array}{r}1998 / 99 \\
\text { Fist. }\end{array}$ \\
\hline & \multicolumn{4}{|c|}{ (In billions of tich) } & \\
\hline Consumption & 1,329 & 1,461 & 1,598 & 1,788 & 1,979 \\
\hline Publitic & 69 & 73 & 80 & 95 & 102 \\
\hline Privgte & 1,260 & 1,389 & 1,518 & 1,693 & 1,877 \\
\hline Gross fixed capitzl formation $1 f$ & 313 & 343 & 371 & 427 & 462 \\
\hline Public $\mathbf{L}$ & 113 & 105 & 116 & 120 & 130 \\
\hline Private & 200 & 237 & 255 & 307 & 332 \\
\hline Demestic derrand & 1,642 & 3,804 & 1,969 & 2,215 & 2,441 \\
\hline Net expouts & -99 & -127 & -108 & -99 & -119 \\
\hline Exparts of goods and nfs & 166 & 184 & 217 & 267 & 291 \\
\hline Inponts of goods and nfs. & 265 & 311 & 326 & 366 & 410 \\
\hline Gross domestic expenditure (GDE) & 1,444 & 1,677 & 1,860 & 2,116 & 2,322 \\
\hline GDP at macket pricos & 1,512 &, \pm 648 & 1,765 & 1,93 & 2,005 \\
\hline Statistical dischepponcy & 68 & -29 & .95 & -177 & -227 \\
\hline Net factor income from abread & 56 & 60 & 71 & 74 & 88 \\
\hline Groses notional product & 1,500 & 1,737 & 1,931 & 2,190 & 2,410 \\
\hline Ofilicinl current tremefers & 36 & 28 & 31 & 22 & 25 \\
\hline Gress notlodisposable inctame & 0.536 & 1,765 & 1,962 & 2.212 & 2,435 \\
\hline National asving & 207 & 304 & 364 & 424 & 456 \\
\hline Gress domestic seving 2 & 115 & 216 & 202 & 328 & 340 \\
\hline Gross domestio saving 3 ; & 183 & 187 & 167 & 151 & 116 \\
\hline \multirow[t]{2}{*}{ Foreign soving $4 /$} & -106 & -39 & -7 & -3 & -6 \\
\hline & \multicolumn{5}{|c|}{ (in percent of GDP) } \\
\hline Consumption & 87.9 & 88.6 & 90.5 & 92.2 & 94.5 \\
\hline Publix & 4.6 & 4.4 & 4.5 & 49 & 4.9 \\
\hline Private & 83.3 & 84.2 & 86.0 & 87.3 & 89.6 \\
\hline Gross fixed capital formation $\mathrm{V}$ & 20.7 & 20.8 & 21.0 & 220 & 22.0 \\
\hline Public Ji & 7.5 & 6.4 & 6.6 & 6.2 & 6.2 \\
\hline Pivate & 13.2 & 14,4 & 14.4 & 15.8 & 15,8 \\
\hline Domeatio demend & 108.6 & 109.4 & 1116 & 114.2 & 116.5 \\
\hline Net exports & -6.5 & -7.7 & .6 .2 & -5.1 & -5.7 \\
\hline Furports of goods and nfs. & 11.0 & 11.2 & 123 & 13.8 & 13.9 \\
\hline Inports of goods and nfs. & 37.5 & 18.9 & 18.4 & 18.9 & 29.6 \\
\hline Stralistical discrepency & 4.5 & -1.7 & .5 .4 & -9.1 & -10.8 \\
\hline GDP al market priees & 100.0 & 1000 & 1000 & 100.0 & 100.0 \\
\hline \multicolumn{6}{|l|}{ Mersoranditum itens! } \\
\hline National asving & 13.7 & 18.4 & 20.6 & 21.9 & 21.8 \\
\hline Gross dornestic saving 2 & 7.6 & 13.1 & 24.8 & 16.9 & 36.4 \\
\hline Gross domestic saving 3 ' & $12:$ & 11.4 & 9.5 & 7.8 & 5.5 \\
\hline Forcigaving 4 & .7 .0 & -2.4 & -0.4 & -0.2 & .0 .3 \\
\hline
\end{tabular}

Solmes: Bangladech Buragu of Statixtics; and Find staff extimates,

1/ Dats based on 1989190 benchmart xnd prices; public investrnent estimatea based on estimates for ADP and non-ADP capital expenditure as reflected in the aentral government's nocounts.

2 GOE minus consurnption.

3/ GDP minus consuraption

A Notional saving minus pross invertonent. 
Table 4. Bangladesh: Agricultural Production, 1994/95-1998/99

\begin{tabular}{|c|c|c|c|c|c|}
\hline & $1994 / 95$ & $1995 / 96$ & $1996 / 97$ & $1997 / 98$ & $\begin{array}{r}\text { Prov. } \\
1998 / 99\end{array}$ \\
\hline & \multicolumn{5}{|c|}{ (In millions of metric tons; unless otherwise indicated) } \\
\hline Foodgrain & 18.1 & 19.1 & 20.4 & 20.5 & 21.3 \\
\hline Rice & 16.8 & 17.7 & 18.9 & 38.8 & 19.3 \\
\hline Aus & 1.8 & 1.7 & 1.9 & 1.9 & $1.61 /$ \\
\hline Aman & 8.5 & 8.8 & 9.5 & 8.8 & 7.71 \\
\hline Boro & 6.5 & 7.2 & 7.5 & 8.1 & 10.0 \\
\hline Wheat & 1.3 & 1.4 & 1.5 & 1.8 & 2.0 \\
\hline Jute (million bales) & 5.2 & 4.1 & 4.9 & 5.8 & $4.5 \mathrm{l}$ \\
\hline Tea (million kilograms) & 51.7 & 47.7 & 53.0 & 51.0 & $\ldots$ \\
\hline Cottan (000 bales) & 69.8 & 75.9 & 95.8 & 200.0 & $\ldots$ \\
\hline Oilseed & 0.5 & 0.5 & 0.4 & 0.5 & $\ldots$ \\
\hline Pulses & 0.5 & 0.5 & 0.5 & 0.5 & $\cdots$ \\
\hline Potatoes & 1.9 & 1.9 & 1.9 & 1.9 & 2.0 \\
\hline Tobacco (000 metric tons) & 37.8 & 39.4 & 38.0 & 37.0 & $\ldots$ \\
\hline Sugarcane & 7.5 & 7.2 & 7.5 & 7,4 & $\cdots$ \\
\hline Fruits & 1.6 & 1.6 & 1.5 & 1.6 & $\cdots$ \\
\hline \multirow[t]{2}{*}{ Vegetables } & 1,3 & 1.2 & 1.2 & 1.4 & $\cdots$ \\
\hline & \multicolumn{5}{|c|}{ (In millions of acres) } \\
\hline Area under cultivation & 33.2 & 33.4 & 33.9 & 34.0 & $\ldots$ \\
\hline Foodgrain & 25.5 & 26.3 & 27.4 & 27.4 & $\ldots$ \\
\hline Rice & 24.0 & 24.6 & 25.6 & 25.4 & $\ldots$ \\
\hline Aus & 14.2 & 3.8 & 3.9 & 3.9 & 3.5 \\
\hline Aman & 13.9 & 14.0 & 14.3 & 14.5 & 1.8 \\
\hline Boto & 6.1 & 6.8 & 7.4 & 7.0 & $\ldots$ \\
\hline Wheat & 1.6 & 1.7 & 1.8 & 2.0 & $\ldots$ \\
\hline Jute & 1.4 & 1.1 & 1.3 & 1.4 & 1.2 \\
\hline \multirow[t]{2}{*}{ Other } & $\ldots$ & 6.0 & 5.2 & 5.2 & $\cdots$ \\
\hline & \multicolumn{5}{|c|}{ (In thousands; end of period) } \\
\hline \multicolumn{6}{|c|}{ Operating irrigation equipment } \\
\hline Deep tubewells & 26.7 & 27.1 & 25.2 & 25.0 & $\ldots$ \\
\hline Shallow tubewells & 488.9 & 576.2 & 629.8 & 689.6 & $\ldots$ \\
\hline Low-lift pumps & 57.1 & 60.6 & 62.9 & 64.2 & $\cdots$ \\
\hline
\end{tabular}

Sources: Bangladesh Buregu of Statistics, Ministry of Agriculture, and Ministry of Food. 1/ Indicates final estimates. 
Table 5. Bangladesh: Jute Goods Statistics, 1994/95-1998/99

\begin{tabular}{|c|c|c|c|c|c|}
\hline & $1994 / 95$ & $1995 / 96$ & $1996 / 97$ & $\begin{array}{r}\text { Est. } \\
1997 / 98\end{array}$ & $\begin{array}{r}\text { Prel. } \\
\text { Est. } \\
1998 / 99\end{array}$ \\
\hline & \multicolumn{5}{|c|}{ (In thousands of metric tons) } \\
\hline Total availability & 607.8 & 555.0 & 549.0 & 611.0 & 651.0 \\
\hline Initial stock & 77.3 & 37.0 & 29.0 & 51.0 & 141.0 \\
\hline Production & 530.5 & 518.0 & 520.0 & 560.0 & 510.0 \\
\hline Domestic use & 74.4 & 82.0 & 90.0 & 100.0 & 87.0 \\
\hline Exports 1/ & 480.6 & 444.0 & 407.0 & 370.0 & 433.0 \\
\hline Hessian & 112.5 & 98.0 & 79.0 & 70.0 & 105.8 \\
\hline Sacking & 188.2 & 162.0 & 153.0 & 140.0 & 137.7 \\
\hline Carpet backing & 48.3 & 54.0 & 33.0 & 30.0 & 25.6 \\
\hline Other & 131.6 & 130.0 & 142.0 & 130.0 & 163.9 \\
\hline Adjustments & 16.2 & 0.0 & 0.0 & 0.0 & -38.0 \\
\hline \multirow[t]{2}{*}{ Closing stock } & 37.0 & 29.0 & 51.0 & 141.0 & 93.0 \\
\hline & \multicolumn{5}{|c|}{ (In U.S. dollars per metric ton) } \\
\hline \multicolumn{6}{|l|}{$\begin{array}{l}\text { Memorantum item: } \\
\text { Export prices }\end{array}$} \\
\hline Hessian & 658 & 825.2 & 873.0 & 710.0 & 626.0 \\
\hline Sacking & 395 & 466.2 & 581.0 & 545.0 & 409.0 \\
\hline Carpet backing & 710 & 809.4 & 806.0 & 750.0 & 715.0 \\
\hline
\end{tabular}

Sources: Prices provided by the Bangladesh Jute Mills Corporation; and other data provided by the Ministry of Jute.

1/ Figures shown do not correspond to balance of payments data; some private mills' production of jute yarns and tine is not included. 
Table 6. Bangladesh: Public Food Distribution, 1994/95-1998/99

\begin{tabular}{|c|c|c|c|c|c|}
\hline & $1994 / 95$ & $1995 / 96$ & $1996 / 97$ & $1997 / 98$ & $\begin{array}{r}\text { Prel. } \\
\text { 1998/99 }\end{array}$ \\
\hline & \multicolumn{5}{|c|}{ (In thousands of metric tons) } \\
\hline Opening stocks & 542 & 772 & 933 & 861 & 629 \\
\hline Rice & 238 & 378 & 613 & 395 & 351 \\
\hline Wheat & 304 & 394 & 320 & 466 & 278 \\
\hline Domestic procurement & 276 & 422 & 616 & 617 & 752 \\
\hline Rice & 246 & 353 & 513 & 399 & 495 \\
\hline Wheat & 30 & 69 & 103 & 218 & 257 \\
\hline Imports & 1,555 & 1577 & 730 & 796 & 1,996 \\
\hline Rice & 230 & 488 & 19 & 92 & 393 \\
\hline Aid imports & 0.0 & 1 & 10 & 0 & 59 \\
\hline Commercial imports & 230 & 487 & 9 & 92 & 334 \\
\hline Wheat & 1,325 & 1089 & 711 & 704 & 1,603 \\
\hline Ajd imports & 935 & 737 & 608 & 549 & 1,174 \\
\hline Commercial imports & 390 & 352 & 103 & 155 & 429 \\
\hline Offtake & 1,573 & 1794 & 1392 & 1,621 & 2,134 \\
\hline Rice & 329 & 593 & 739 & 529 & 530 \\
\hline Ration sales & 107 & 119 & 121 & 125 & 142 \\
\hline Food-for-Work & 7 & 1.0 & 127.0 & 3.0 & 8 \\
\hline Food for education & 6 & 4.0 & 210.0 & 71.0 & 60 \\
\hline VGD, VGF, \& relief & $\$ 3$ & 65 & 281 & 167 & 318 \\
\hline Open market sales & 156 & 404 & 0 & 163 & 2 \\
\hline Wheat & 1,244 & 1,201 & 653 & 1,092 & 1,604 \\
\hline Ration sales & 143 & 114 & 68 & 102 & 109 \\
\hline Food-for-work & 492 & 468 & 111 & 466 & 690 \\
\hline Food for education & 168 & 237.0 & 332.0 & 270.0 & 227 \\
\hline VGD, VGF, \& relief & 337 & 372 & 92 & 247 & 571 \\
\hline Four mills & 33 & 10 & 50 & 8 & 7 \\
\hline Open market sales & 70 & 0 & 0 & 0 & 0 \\
\hline Losses & 28 & 44 & 26 & 24 & 46 \\
\hline Rice & 7 & 13 & 11 & 6 & 14 \\
\hline Wheat & 21 & 31 & 15 & 18 & 31 \\
\hline Closing stocks & 772 & 933 & 861 & 629 & 1,198 \\
\hline Rice & 378 & 613 & 395 & 351 & 695 \\
\hline Wheat & 394 & 320 & 466 & 278 & 503 \\
\hline
\end{tabular}

Source: Ministry of Food. 
Table 7. Bangladesh: Fertilizer Statistics, 1994/95-1998/99

\begin{tabular}{|c|c|c|c|c|c|}
\hline & $1994 / 95$ & $1995 / 96$ & $1996 / 97$ & $1997 / 98$ & $1998 / 99$ \\
\hline & \multicolumn{5}{|c|}{ (In thousands of metric tons) } \\
\hline Total availability & 3,197 & 2,840 & 2,708 & 2,319 & 2,286 \\
\hline Opening stock & 407 & 191 & 277 & 130 & 452 \\
\hline Domestic production & 2,140 & 2,241 & 1,985 & 1,883 & 1,607 \\
\hline Imports & 650 & 408 & 446 & 306 & 227 \\
\hline Sales & 3,006 & 2,563 & 2,578 & 1,867 & 1,898 \\
\hline Local & 2,564 & 2,165 & 2,234 & 1,867 & 1,874 \\
\hline Exports & 442 & 398 & 344 & 0 & 24 \\
\hline \multirow[t]{2}{*}{ Closing stock } & 191 & 277 & 130 & 452 & 388 \\
\hline & \multicolumn{5}{|c|}{ (In taka per metric ton) } \\
\hline \multicolumn{6}{|l|}{ Domestic wholesale prices } \\
\hline Urea & 3,725 & 3,725 & 4,800 & 4,800 & 4,800 \\
\hline Single super phosphate & 3,600 & 3,600 & 3,600 & 3,900 & 3,900 \\
\hline Triple superphosphate & 6,860 & 6,860 & 6,860 & 8,500 & 8,500 \\
\hline
\end{tabular}

Sources: Bangladesh Chemical Industries Corporation (BCIC), Bangiadesh Agricultural Development Corporation (BADC). 
Table 8. Bangladesh: Manufacturing Production by Main Categories, 1994/95-1998/99 1/

\begin{tabular}{|c|c|c|c|c|c|c|}
\hline & Weights & $1994 / 95$ & $1995 / 96$ & $1996 / 97$ & $1997 / 98$ & $\begin{array}{r}\text { Prov. } \\
1998 / 99\end{array}$ \\
\hline & \multicolumn{6}{|c|}{ (Volume Index; $198 \mathrm{~B} / 89=100$ ) } \\
\hline Overall & 100.0 & 163.3 & 173.5 & 179.3 & 195.9 & 199.6 \\
\hline Food, beverages, and tobacco & 22.1 & 172.1 & 154.6 & 162.6 & 170.7 & 171.2 \\
\hline $\begin{array}{l}\text { Jute, textiles, and leather } \\
\text { Of which }\end{array}$ & 38.2 & 159.2 & 180.3 & 195.7 & 222.3 & 240.6 \\
\hline Garments & 9.4 & 281.0 & 440.0 & 507.2 & 667.1 & 699.6 \\
\hline Wood products & 0.2 & 129.7 & 137.3 & 150.6 & 158.4 & 178.5 \\
\hline Paper and paper products & 4.7 & 242.1 & 259.8 & 258.6 & 259.9 & 294.3 \\
\hline $\begin{array}{l}\text { Chemicals, fertilizer, } \\
\text { petroleum, and rubber }\end{array}$ & 24.0 & 168.9 & 182.4 & 178.8 & 183.2 & 173.8 \\
\hline Nommetallic products & 2.8 & 96.9 & 113.7 & 141.4 & 149.9 & 152.3 \\
\hline Basic metal products & 2.1 & 182.9 & 159.2 & 172.6 & 186.4 & 160.4 \\
\hline \multicolumn{7}{|l|}{ Fabricated metal } \\
\hline & \multicolumn{6}{|c|}{ (Anmual percent change) } \\
\hline Overall & 100.0 & 6.1 & 6.2 & 3.3 & 9.3 & 1.9 \\
\hline Food, beverages, and tobacco & 22.1 & 13.8 & -4.4 & -1.2 & 5.0 & 0.3 \\
\hline $\begin{array}{l}\text { Jute, textiles, and leather } \\
\text { Of which }\end{array}$ & 38.2 & -0.7 & 13.2 & 8.5 & 17.2 & 4.9 \\
\hline Garments & 9.1 & 2.7 & 56.6 & 15.3 & 31.5 & 4.9 \\
\hline Wood products & 0.2 & 10.2 & 5.8 & 9.7 & 5.2 & 127 \\
\hline Paper and paper products & 4.7 & 13.3 & 7.3 & -0.5 & 0.5 & 13.2 \\
\hline $\begin{array}{l}\text { Chemicals, fertilizer, } \\
\text { petroleum, and rubber }\end{array}$ & 24.0 & 5.4 & 8.0 & -2.0 & 2.5 & -5.1 \\
\hline Nonmetalic products & 2.8 & -8.0 & 17.3 & 24.4 & 6.0 & 1.6 \\
\hline Basic metal products & 2.1 & 66.5 & -13.0 & 8.4 & 8.0 & -13.9 \\
\hline Fabricated metal products & 59 & 12.2 & $-9,2$ & 5.5 & 7.2 & 1.7 \\
\hline
\end{tabular}

Source: Bangladesh Bureau of Statistics.

1/ Exchuding mining and electricity. 
Table 9. Bangladesh: Energy Statistics, 1994/95-1998/99

\begin{tabular}{|c|c|c|c|c|c|}
\hline & $1994 / 95$ & $1995 / 96$ & $1996 / 97$ & $1997 / 98$ & $\begin{array}{r}\text { Prov. } \\
1998 / 99\end{array}$ \\
\hline & \multicolumn{5}{|c|}{ (In thousands of metric tons) } \\
\hline \multicolumn{6}{|l|}{ Petroleum products } \\
\hline Imports & 1,115 & 1,508 & 1,644 & 1,422 & 2,222 \\
\hline Domestically refined & 1,371 & 1,160 & 1,300 & 1,426 & 973 \\
\hline Consumption & 2,416 & 2,484 & 2,834 & 2,578 & 3,000 \\
\hline \multicolumn{6}{|l|}{ Exports and change } \\
\hline in stocks & 70 & 184 & 140 & 270 & 195 \\
\hline & \multicolumn{5}{|c|}{ (In millions of cubic feet) } \\
\hline \multicolumn{6}{|l|}{ Natural gas } \\
\hline Production & 247,413 & 265,565 & 260,990 & 282,007 & 307,476 \\
\hline Consumption & 233,817 & 252,887 & 244,609 & 265,432 & 291,042 \\
\hline Power & 107,462 & 110,898 & 110,820 & 123,551 & 140,817 \\
\hline Fertilizer & 80,411 & 90,978 & 77,834 & 80,074 & 82,707 \\
\hline Industry & 24,155 & 27,305 & 28,678 & 32,315 & 35,793 \\
\hline Commercial & 3,708 & 2,997 & 4,494 & 4,607 & 4,705 \\
\hline Domestic & 18,081 & 20,709 & 22,843 & 24,885 & 27,020 \\
\hline \multirow[t]{2}{*}{ System losses } & 13,596 & 12,629 & 16,381 & 16,575 & 16,434 \\
\hline & \multicolumn{5}{|c|}{ (In millions of kilowatt hours) } \\
\hline \multicolumn{6}{|l|}{ Electricity } \\
\hline \multicolumn{6}{|l|}{ Of which } \\
\hline Based on natural gas & 9,512 & 9,994 & 10,021 & 10,896 & 12,278 \\
\hline System losses & 2,435 & 2,478 & 2,411 & 2,492 & $\ldots$ \\
\hline
\end{tabular}

Source: Data provided by the Bangladesh authorities, PDB, BOGMCand BPC. 
Table 10. Bangladesh: Retail Prices of Petroleum Products, 1994/95-1998/99 (End of period)

\begin{tabular}{|c|c|c|c|c|c|c|}
\hline & $1994 / 95$ & $1005 / 06$ & 1006107 & $1007 / 08$ & $1000 / 00$ & $\begin{array}{r}\text { December } \\
1999\end{array}$ \\
\hline & \multicolumn{6}{|c|}{ (In taka per liter) } \\
\hline Premium gasoline & 14.65 & 14.65 & 14.65 & 23.00 & 23.00 & 23.00 \\
\hline Regular gasoline & 13.70 & 13,70 & 13,70 & 21.00 & 21.00 & 21.00 \\
\hline Kerosene & 12.70 & 12.70 & 12.70 & 12.95 & 12.95 & 12.95 \\
\hline Diesel oil & 12.70 & 12.70 & 12.70 & 12.95 & 12.95 & 12.95 \\
\hline Fuel oil & 4.51 & 4.51 & 4.51 & 5.0 & 5.0 & 5.0 \\
\hline \multirow[t]{2}{*}{ Jet oil } & 16.62 & 16.62 & 16.62 & 16.62 & 16.62 & 16.62 \\
\hline & \multicolumn{6}{|c|}{ (In U.S. dollar per gallon) } \\
\hline Premium gasoline & 1.38 & 1.33 & 1.27 & 1.85 & 1.79 & 1.71 \\
\hline Regular gasoline & 1.29 & 1.24 & 1.19 & 1.68 & 1.63 & 1.56 \\
\hline Kerosene & 1.20 & 1.15 & 1.10 & 1.03 & 1.01 & 0.96 \\
\hline Diesel oil & 1.20 & 1.15 & 1.10 & 1.03 & 1.01 & 0.96 \\
\hline Fuel oil & 0.43 & 0.41 & 0.39 & 0.41 & 0.39 & 0.37 \\
\hline Jet oil & 1.57 & 1.51 & 1.44 & 1.32 & 1.29 & 1.24 \\
\hline $\begin{array}{l}\text { Memorandum: } \\
\text { Average crude price } \\
\text { (US\$/barrel) }\end{array}$ & 17.20 & 17.76 & 20.90 & 12.48 & 12.61 & $24.16 \quad 11$ \\
\hline
\end{tabular}

Source: Bangladesh Petroleum Corporation; and staff estimates.

1/ As of November 1999. 
Table 12. Bangladesh: Labour Market Statistics, 1990/91-1995/96 1/

\begin{tabular}{|c|c|c|}
\hline & $1990 / 91$ & $1995 / 96$ \\
\hline Total population (in million) & 111.5 & $122.1(128.1)$ \\
\hline Male & 57.3 & 62.7 \\
\hline Female & 54.2 & 59.4 \\
\hline Population growth rate (percent) $2 /$ & 1.9 & $1.8(1.5)$ \\
\hline Total labour force (In million) 3 / & 51 & 56 \\
\hline Male & 31 & 35 \\
\hline Female & 20 & 21 \\
\hline Types of employment: (In percent) & 100.0 & 100.0 \\
\hline Formal & 11.7 & 12.4 \\
\hline Non-formal & 87.9 & 87.6 \\
\hline Family based & 47.2 & 40.1 \\
\hline Daily basis & 13.9 & 17.9 \\
\hline Self employinent & 26.8 & 29.6 \\
\hline Activitgy-wise employement (In percent) & 100.0 & 100.0 \\
\hline Agriculture, forest, fisheries & 66.4 & 63.2 \\
\hline Mining and rusrrying & $\ldots$ & $\ldots$ \\
\hline Menufacturing & 11.8 & 7.5 \\
\hline Electricity, ges and water & 0.1 & 0.2 \\
\hline Construction & 1.0 & 1.8 \\
\hline Trade services & 8.5 & 11.2 \\
\hline Transport and communication & 3.2 & 4.2 \\
\hline Finance, business service & 0.6 & 0.4 \\
\hline Community, personal service & 3.8 & 9.3 \\
\hline Others & 4.5 & 2.2 \\
\hline Wage rate index (general) $(1969-70=100)$ & 1,482 & $1,900(2,259)$ \\
\hline Agrienlture & 1,321 & $1,738(1,950)$ \\
\hline Manufacturing & 1,575 & $2,064(2,522)$ \\
\hline Construction & 1,487 & $1,754(2,163)$ \\
\hline CPI for industrial workers (1969-70=100) & 1,386 & $1,674(1,921)$ \\
\hline
\end{tabular}

Source: Bangladesh Bureau of Statisties and Ministry of Finance.

1/Based on labour force surveys. Figures in paranthesis refer to 1998/99.

2/ Natural growth rate (Crude Birth Rate minus Crude Death Rate).

3/ Aged 10 years and above. 
Table 13. Bangladesh: Central Govermment Operations, 1994/95-1999/2000

\begin{tabular}{|c|c|c|c|c|c|c|c|c|}
\hline & & & & & $\begin{array}{l}\text { Initial } \\
\text { Budget } \text { V }\end{array}$ & $\begin{array}{c}\text { Pastrflood } \\
\text { Budgat }\end{array}$ & Est. & - Budget \\
\hline & $1994 / 95$ & $1995 / 96$ & $1996 / 97$ & $1997 / 98$ & \multicolumn{2}{|c|}{$1998 / 99$} & & $1999 / 2000$ \\
\hline & \multicolumn{8}{|c|}{ (In billions of talpa) } \\
\hline Total revenue & 141.8 & 150.3 & 165.9 & 185.5 & 210.0 & 206.0 & 198.1 & 241.2 \\
\hline $\operatorname{Tax}$ & 111.9 & 120.0 & 133.1 & 147.0 & 167.3 & 164.0 & $\$ 58.4$ & 185.1 \\
\hline Taxes on inoome and profits & $\mathbf{1 4 . 8}$ & 15.0 & 16.4 & 20.0 & 24.5 & 23.0 & 23.5 & 27.8 \\
\hline VAT & 34.6 & 38.2 & 42.8 & 46.4 & 51.0 & 50.4 & 48.4 & 56.4 \\
\hline Supplementary VAT and excises & 17.1 & 20.4 & 23.0 & 25.6 & 29.8 & 30.2 & 27.1 & 29,6 \\
\hline Taxes on interrational trade & 36.8 & 37.7 & 40.1 & 43.5 & 50.3 & 48.7 & 47.4 & $\$ 7.5$ \\
\hline Noatax & 299 & 30.2 & 32.8 & 38.5 & 42.7 & 42.0 & 39.7 & 56.2 \\
\hline Total espenditure & 223.0 & 2228 & 244.0 & 267.0 & 303.4 & 307.8 & 303.7 & 347.4 \\
\hline Curreint expenditure & 103.1 & 113.1 & 123.6 & 143.2 & 157.5 & 162.2 & 167.3 & 177.4 \\
\hline Pay and allowences & 39.6 & 42.1 & 43.9 & 46.5 & 48.6 & $\ldots$ & 51.0 & 55.8 \\
\hline Interest & 13.2 & 17.3 & 17.6 & 23.3 & 25.7 & $\ldots$ & 29.4 & 28.1 \\
\hline Subsidies and transfers & 253 & 26.7 & 31.9 & 41.3 & 42.2 & $\ldots$ & 51.5 & 50.1 \\
\hline Food account surplus $(-) /$ deficit $(t)$ & 7.0 & 5.0 & 4.0 & 3.2 & 3.7 & 8.7 & 5.9 & 6.0 \\
\hline Amual Development Program (ADP) 2 & 100.9 & 96.1 & 108.5 & 113.0 & 134,2 & 129,0 & 123.2 & 152.5 \\
\hline Non-ADP capital and net lending $3{ }^{\prime}$ & 12.0 & 8.6 & 8.0 & 7.5 & 8.0 & 8.0 & 7.2 & 11.5 \\
\hline Retidual 4/ & -1.4 & 2.0 & 0.0 & 0.0 & 0.0 & 0.0 & -7.4 & 0.0 \\
\hline Overall budget deficit & 79.8 & 74.5 & 782 & 81.5 & 93.4 & -101.8 & 105,6 & 106.4 \\
\hline Net forreign finsmeing $5 /$ & 57.6 & 46.3 & 51.3 & 48.6 & SS.2 & 67.5 & 53.7 & 65.1 \\
\hline Disbursements & 68.6 & 59.2 & 653 & 64.1 & 71.4 & 83.7 & 699 & 83.6 \\
\hline Amortization & -11.0 & .12 .9 & -14.0 & -15.5 & .16 .2 & -16.2 & -163 & -18.5 \\
\hline Net domestic finareing & 22.2 & 28.1 & 26.8 & 32.9 & 38.2 & 34.3 & 44.5 & 41.0 \\
\hline Banking system $6 I$ & 5.2 & 15.6 & 17.1 & 12.6 & 15.0 & 15.0 & 19.8 & 15.0 \\
\hline \multirow[t]{2}{*}{ Other domestic $\gamma$} & 17.0 & 12.5 & 9.7 & 20.3 & 23.2 & 19.3 & 24.7 & 26.1 \\
\hline & \multicolumn{8}{|c|}{ (In peroent of GDP) } \\
\hline Total revenue & 9.4 & 9.1 & 9.4 & 9.6 & 10.1 & 99 & 9.5 & 10.4 \\
\hline Tax revenue & 7.4 & 7.3 & 7.5 & 7.6 & 8.0 & 7.9 & 7.6 & 8.0 \\
\hline Nontax & 20 & 1.8 & 1.9 & 2.0 & 2.1 & 0.4 & 1.9 & 2.4 \\
\hline Total expenditure & 14.7 & 13.5 & 13.8 & 13.8 & 14.6 & 14.8 & 14,6 & 14.9 \\
\hline Current experaditure & 6.8 & 6.9 & 7.0 & 7.4 & 7.6 & 7.8 & 8.0 & 7.6 \\
\hline Food scocunt surplus $(-j /$ deflett $(+)$ & 0.5 & 0.3 & 0.2 & 0.2 & 0.2 & 0.4 & 0.3 & 0.3 \\
\hline Annual Developtaent Program (ADP) 2 & 6.7 & 5.8 & 6.1 & 5.8 & 6.4 & 6.2 & 5.9 & 6.6 \\
\hline Non-ADP capital and net lending $3 r$ & 0.8 & 0.5 & 0.5 & 0.4 & 0.4 & 0.4 & 0.3 & 0.5 \\
\hline Overall budget balance & -5.3 & .4 .3 & -4.4 & 4.2 & -4.5 & $-4,9$ & -5.1 & -4.6 \\
\hline Net foreigo financing $5 /$ & 3.8 & 2.8 & 2.9 & 2.5 & 2.7 & 3.2 & 2.6 & 28 \\
\hline Net domestic financing & 1.5 & 1.7 & 1.5 & 1.7 & 1.8 & 1.6 & 2.1 & 1.8 \\
\hline Banking system $6 /$ & 0.3 & 0.9 & 1.0 & 0.7 & 0.7 & 0.7 & 1.0 & 0.6 \\
\hline Other domestic $7 /$ & 1.1 & 0.8 & 0.5 & 1.0 & 1.1 & 0.9 & 1.2 & L.1 \\
\hline \multicolumn{9}{|l|}{ Memorandum items: } \\
\hline Publix debt & $\$ 3.3$ & 49.3 & 47.2 & 44.5 & 47.4 & 47.7 & 47.7 & 47.4 \\
\hline External & 42.4 & 37.6 & 34.8 & 31.4 & 33.4 & 33.4 & 33.4 & 32.7 \\
\hline Domestic & 10.9 & 11.7 & 12.3 & 13.0 & 14.0 & 14.3 & 14.3 & 14.8 \\
\hline
\end{tabular}

Sources: Data provided by the Bangladesh surthorities; and Fund staff cotimates.

V/ The Initial Budget column is bered on pre-flood estimates.

2/ Consists of capitat spending, net lending, also some warrent spending and from 1997/98, the Food-for-Work Program

3/ Inchudes the Food-for-Work program, miscellaneous investment, loans and advances, and other expenditurex, until 1996/97; from 1997/98 the Food-for-Work Progrann is classified under ADP.

4/ Difference between the balance of revenues and expenditures from the fiscal accounts and the estimates of total finanaing.

5/ Inchudes foreign grants and loans.

6/ Consistent with net olaims on central government in the monetary scoounts; excludes nes elaims on railways, telephone and telegraph, and other bodies.

$7 /$ Leludes finansing through Nationsl Savings schemes, prize and wage bonds, and the surplus of the National Provident Fund. 
Table 14. Bangladesh: Central Government Revenues, 1994/95-1999/2000

\begin{tabular}{|c|c|c|c|c|c|c|c|}
\hline & \multicolumn{7}{|c|}{ Initial } \\
\hline & \multirow[b]{2}{*}{$1994 / 95$} & \multirow[b]{2}{*}{ 1995/96 } & \multirow[b]{2}{*}{$1996 / 97$} & \multicolumn{2}{|c|}{ Budget 1/ } & \multirow[t]{2}{*}{ Est. } & \multirow{2}{*}{$\begin{array}{c}\text { Budget } \\
1999 / 2000\end{array}$} \\
\hline & & & & $1997 / 98$ & $1998 / 99$ & & \\
\hline & \multicolumn{7}{|c|}{ (In billions of taka) } \\
\hline Total revenue & 141.8 & 150.3 & 165.9 & 185.5 & 210.0 & 198.1 & 241.2 \\
\hline Tax revenue & 111.9 & 120.0 & 133.1 & 147.0 & 167.3 & 158.4 & 185.1 \\
\hline NBR taxes & 105.0 & 113.2 & 124.4 & 138.0 & 158.1 & 148.4 & 173.7 \\
\hline VAT and Supplementary duties & 49.9 & 56,8 & 63.8 & 69.8 & 78.5 & 73.2 & 83.7 \\
\hline VAT & 34.6 & 38.2 & 42.8 & 46.4 & 51.0 & 48.4 & 56.4 \\
\hline Import stage & 22.2 & 25.6 & 27,9 & 29.5 & 32.5 & 30.4 & 36.2 \\
\hline Domestic stage & 12.4 & 12.6 & 14.9 & 16.9 & 18.5 & 18.0 & 20.2 \\
\hline Supplementary duties & 15.3 & 18.6 & 21.0 & 23.4 & 27.5 & 24.8 & 27.3 \\
\hline Supplementary import & 1.9 & 3.6 & 4.5 & 62 & 6.5 & 7.7 & 9.0 \\
\hline Supplementary domestic & 13.4 & 15.0 & 16.4 & 17.2 & 21.0 & 17.1 & 18.3 \\
\hline Exolse taxes & 1.8 & 1.8 & 2.0 & 22 & 2.3 & 2.2 & 2.3 \\
\hline Customs duties & 36.8 & 37.7 & 40.1 & 43.5 & 50.3 & 47.4 & 57.5 \\
\hline Income and profits taxer & 14.8 & 15.0 & 16.4 & 20.0 & 24.5 & 23.5 & 27.8 \\
\hline Other taxes & 1.8 & 1.9 & 2.1 & 2.5 & 2.6 & 20 & 2.4 \\
\hline Other non NBR taxes & 6.9 & 6.8 & 8.7 & 9.0 & 9.2 & 10.1 & 11.4 \\
\hline \multirow[t]{2}{*}{ Nontax revenue } & 29.9 & 30.2 & 32.8 & 38.5 & 42.7 & 39.7 & 56.2 \\
\hline & \multicolumn{7}{|c|}{ (In percent of (GDP) } \\
\hline Total revenue & 9.4 & 9.1 & 9.4 & 9.6 & 10.1 & 9.5 & 10.5 \\
\hline Tax revenue & 7.4 & 7.3 & 7.5 & 7.6 & 8.0 & 7.6 & 8.1 \\
\hline NBR taxes & 6.9 & 6.9 & 7,0 & 7.1 & 7.6 & 7.1 & 7.6 \\
\hline VAT and Supptementary duties & 3.3 & 3.4 & 3.5 & 3.5 & 3.8 & 3.5 & 3.6 \\
\hline VAT & 2.3 & 2.3 & 2.4 & 2.4 & 2.5 & 23 & 2.5 \\
\hline Supplementary duties & 1.0 & 1.1 & 1.2 & 1.2 & 1.3 & 12 & 1.2 \\
\hline Excise taxes & 0.1 & 0.1 & 0.1 & 0.1 & 0.1 & 0.1 & 0.1 \\
\hline Customs duties & 2.4 & 2.3 & 2.3 & 2.3 & 2.4 & 23 & 2.5 \\
\hline Income and profits taxes & 1.0 & 0.9 & 0.9 & 1.0 & 1.2 & 1.1 & 1.2 \\
\hline Other taxes & 0.1 & 0.1 & 0.1 & 0.1 & 0.1 & 0.1 & 0.1 \\
\hline Other non NBR taxes & 0.5 & 0.4 & 0.5 & 0.5 & 0.4 & 0.5 & 0.5 \\
\hline Nontax revenue & 2.0 & 1.8 & 1.9 & 2.0 & 2.1 & 1.9 & 2.4 \\
\hline
\end{tabular}

Sources: Bangladesh authorities; and Fund staff estimates.

1/ Figures reflect pre-flood budget cstimates. 
Table 15. Bangladesh: Central Government Current Expenditure by Economic Classification, 1994/95-1999/2000

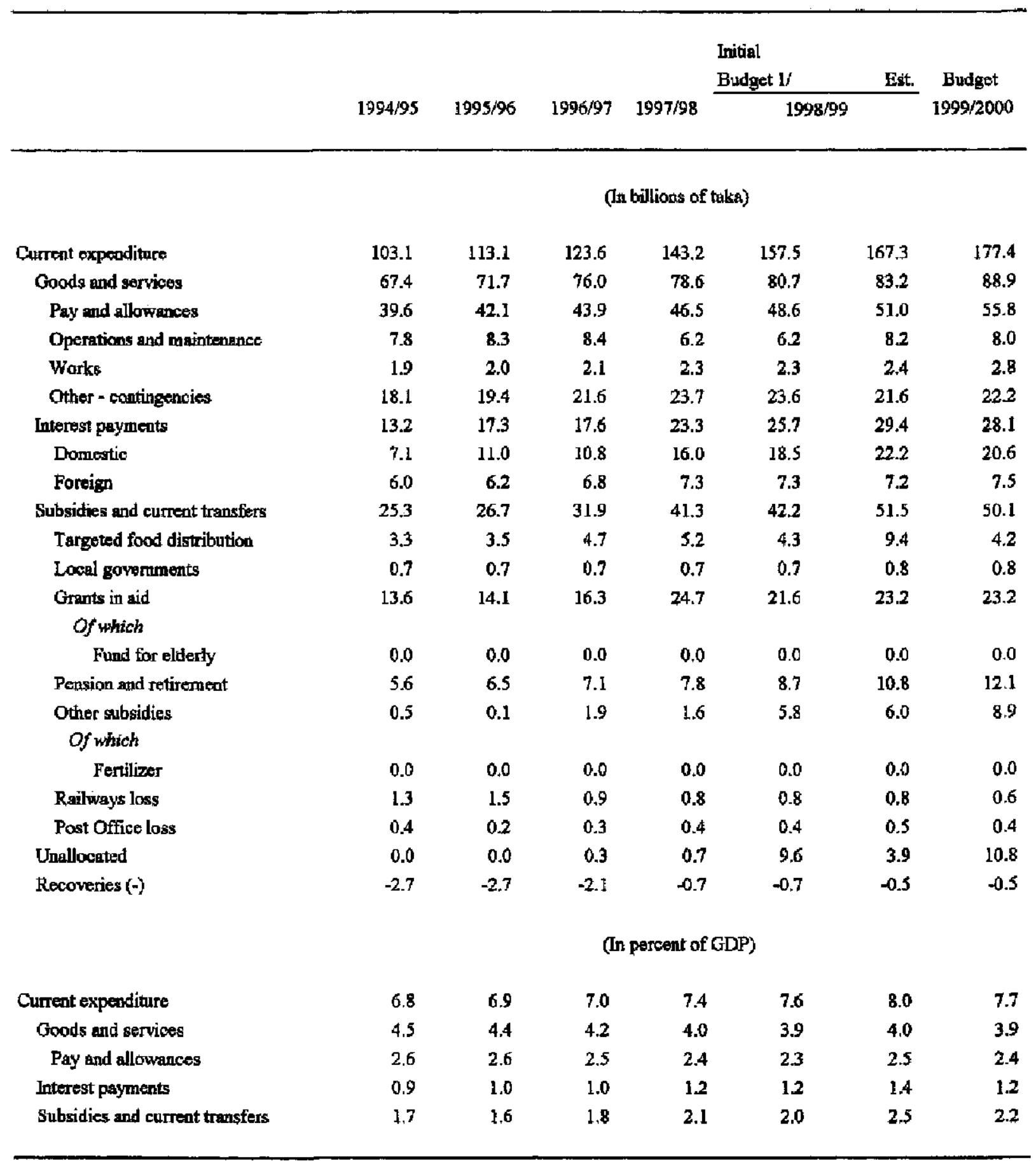

Sources: Bangladesh sithorities; and Fund staff estimates.

1/ Figures reflect pro-flood budget estimates. 
Table 16. Bangladesh: Amual Development Program by Sector, 1994/95-1999/2000 U

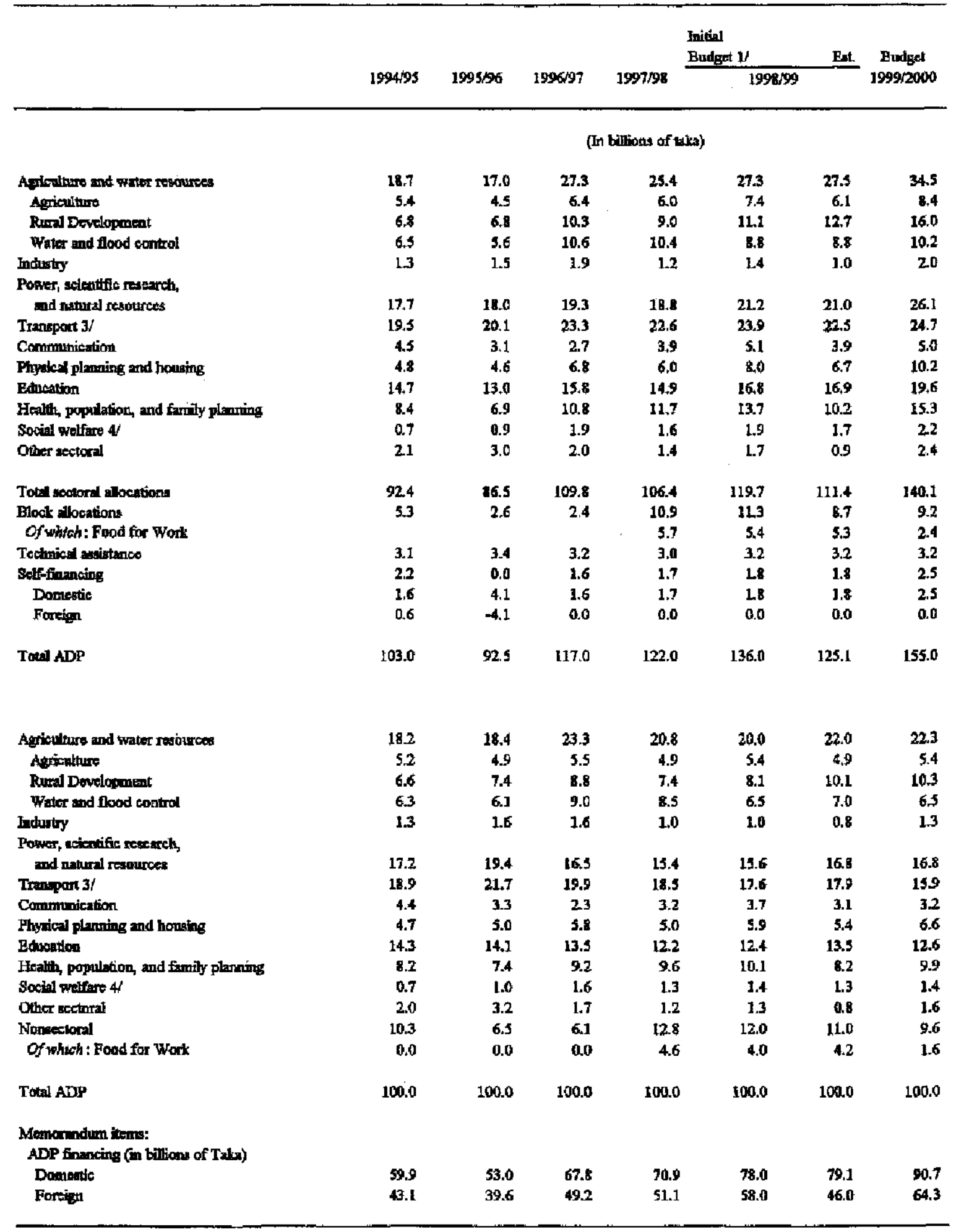

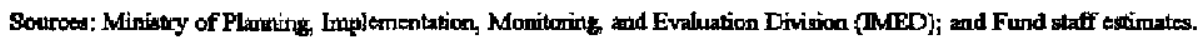

1/ The ageregate ADP expeaditure figures provided by the ERD may not correxpnad to those calculated by the MMED; intial budget figures for 1998/99 reflect pre-flood estimates.

$2 /$ The 1997/98 extimate represent the revised budgot.

3/ Inchudea Jampuca Bidge.

4/ Irioludes employzrent. 
Table 17. Bangladesh: Central Government Food Account, 1994/95-1999/2000

(In billions of taka)

\begin{tabular}{|c|c|c|c|c|c|c|c|}
\hline & & & & & Initial & Fet & Redont \\
\hline & $1994 / 95$ & $1995 / 96$ & $1996 / 97$ & $1997 / 98$ & $1998 / 99$ & & $1999 / 2000$ \\
\hline Expenditures & 18.1 & 21.9 & 19.0 & 21.3 & 22.6 & 28.3 & 24.5 \\
\hline Imports & 11.3 & 14.3 & 6.7 & 10.0 & 9.0 & 17.6 & 11.9 \\
\hline Grants and loans & 6.1 & 6.0 & 5.5 & 5.7 & 5.4 & 8.1 & 7.4 \\
\hline Commetcinl (cash) & 5.2 & 8.3 & 1.2 & 4.3 & 3.5 & 9.5 & 4.5 \\
\hline Domestic procurement & 3.5 & 4.4 & 8.8 & 8.0 & 10.4 & 7.0 & 8.7 \\
\hline Extemal freight & 0.3 & 0.2 & 0.2 & 0.2 & 0,2 & 0.2 & 0.2 \\
\hline Operating expenses 2/ & 3.0 & 3.0 & 3,3 & 3.1 & 3.1 & 3.5 & 3.7 \\
\hline Receipts & 11.0 & 16.9 & 15.0 & 18. $\mathrm{I}$ & 18.9 & 22.4 & 18.5 \\
\hline Gross sales receipts & 3.3 & 7.9 & 4.1 & 6.8 & 7.7 & 4,9 & 7.5 \\
\hline Nonmonetized distribution $3 /$ & 7.7 & 9.1 & 10.9 & 11.4 & 11.2 & 17.5 & $1 I .0$ \\
\hline Food for Wotk & 4.2 & 5.0 & 6.2 & 6.2 & 6.2 & 7.2 & 6.2 \\
\hline Vulnerable Group & 3.5 & 4.0 & 4.7 & 5.2 & 5.0 & 10.3 & 4.9 \\
\hline Food account balance & .7 .0 & -5.0 & -4.0 & -3.2 & -3.7 & -5.9 & -6.0 \\
\hline Subsidies on sates & -2.7 & -3.0 & -3.5 & -3.9 & -4.1 & -3.3 & -3.8 \\
\hline Expenditure on change & 0.0 & 0.0 & 0.0 & 0.0 & 0.0 & 0.0 & 0.0 \\
\hline In stocks & -4.4 & -2.0 & -0.6 & 0.7 & 0.4 & -2.6 & -2.2 \\
\hline
\end{tabular}

Sources: Ministry of Finance, Ministry of Food; and Fund staff estimates.

1/ Figures reflect pre-flood budget estimates.

2/ As of $1989 / 90$, establishment costs are included in operating expenses.

3/ This item represents the valuation of nommonctized distribution. In effoct, it represents transfers to the food account from other expenditure categories.

(C) International Monetary Fund. Not for Redistribution 
Table 18. Bangladesh: Consolidated Accounts of Nonfinancial Public Enterprises, 1994/95-1999/2000 (In billions of taka)

\begin{tabular}{|c|c|c|c|c|c|c|c|}
\hline & $1994 / 95$ & $1995 / 96$ & $1996 / 97$ & $1997 / 98^{\circ}$ & $\frac{\text { Budget }}{1998 / 99}$ & Est. & $\begin{array}{l}\text { Budgot } \\
1999 / 2000\end{array}$ \\
\hline Operating revenue $1 /$ & 156.1 & 163.8 & 169.1 & 186.7 & 214.9 & 210.6 & 235.6 \\
\hline Operating expenditure & 152.1 & 161.8 & 176.2 & 183.6 & 211.7 & 211.5 & 235.0 \\
\hline Woges and salaries & 14.6 & 15.6 & 15.4 & 15.9 & 18.2 & 17.5 & 19.3 \\
\hline Purcheses of goods and services & 119.2 & 134.1 & 145.7 & 151.2 & 177.3 & 175.8 & 194.8 \\
\hline Depreciation & 18.3 & 12.1 & 15.1 & 16.5 & 16.2 & 18.2 & 20.9 \\
\hline Operating surplus & 4,0 & 2.0 & -7.1 & 3.1 & 3.2 & .0 .9 & 0.6 \\
\hline Nopoperating income & -0.2 & 5.3 & 2.8 & 3.6 & 2.3 & 3.7 & 2.5 \\
\hline Interest payments & -8.0 & .7 .5 & 8.4 & -9.8 & -9.3 & -10.2 & -10.0 \\
\hline lneome before taxes & 4.2 & -0.2 & -12.7 & -3.1 & -3.8 & -7.4 & .6 .9 \\
\hline Profit distributions & 2.2 & 2.3 & 1.7 & 2.6 & 4.3 & 3.3 & 5.0 \\
\hline Dividends & 2.0 & 2.1 & 1.5 & 1.8 & 4.0 & 3.1 & 5.0 \\
\hline Profit sharing & 0.2 & 0.2 & 0.2 & 0.2 & 0.3 & 0.2 & 0.3 \\
\hline Ineome tax & 2.1 & 1.5 & 1.0 & 1.2 & 1.6 & 1.5 & 1.9 \\
\hline After-tax retained income & -8.4 & 4.0 & -15.4 & -6.3 & -9.7 & -12.2 & 14.1 \\
\hline Gross savings $2 /$ & 9.9 & 8.1 & -0.3 & 10.2 & 6.5 & 6.5 & 7.6 \\
\hline Gross fixed capital formation & 24.3 & 26.2 & 24.8 & 31.6 & 48.4 & 50.9 & 80.2 \\
\hline Financing & 14.4 & 18.] & 24.9 & 21.4 & 41.8 & 44.4 & 72.6 \\
\hline Ner long-term borrowing & 1.2 & 9.4 & 4.5 & 5.6 & 9.0 & 13.7 & 31.9 \\
\hline Drawings & 14.7 & 21.2 & 14.9 & 18.6 & 21.3 & 30.3 & 50.5 \\
\hline Repayments & -13.5 & -11.8 & -20.4 & -13.0 & -12.3 & -16.6 & -18.6 \\
\hline Equity injection & 9.1 & 6.8 & 10.8 & 8.9 & 20.0 & 10.9 & 17.0 \\
\hline Finance deficit 3 & 4.1 & 1.9 & 9.6 & 6.9 & 12,8 & 19.8 & 22.1 \\
\hline \multicolumn{8}{|l|}{ Memorandum items: } \\
\hline Total assets & 631.1 & 634.0 & 680.0 & 717.3 & 777.3 & 759.4 & 796.1 \\
\hline Equity & 212.4 & 214.6 & 231.3 & 234.3 & 251.8 & 230.7 & 287.8 \\
\hline Debt & 418.7 & 419.4 & 448.7 & 483.0 & 525.5 & 528.7 & 508.3 \\
\hline Employment (thousands) & 256.9 & 258.4 & 253.4 & 252.5 & 244.0 & 249.5 & 251.8 \\
\hline \multicolumn{8}{|l|}{ Profitability (in percent) } \\
\hline Oporating sturplus/operating revenues & 2.5 & 1.2 & 42 & 1.7 & 1.5 & -0.4 & 0,3 \\
\hline Oporating surplus/assets & 0.6 & 0.3 & .10 & 0.4 & 0.4 & -0.1 & 0.1 \\
\hline
\end{tabular}

Source: Ministry of Finaree, Autonomous Bodies Wing and Finance Division; and staff estimates.

11. Does not include changes in inventorios.

2f Defined as after-tax retained income plus depreciation.

3/ Includes arrears to Govemiment and changes in donestic bank debt (including arrears). 
Table 19. Bangladesh: Profits of Nonfinancial Public Enterprises, 1994/95-1999/2000

(In millions of taka)

\begin{tabular}{|c|c|c|c|c|c|c|c|}
\hline & $1994 / 95$ & $1995 / 95$ & $1996: 97$ & $1997 / 98$ & $\frac{\text { Budget }}{1998}$ & Est. & $\begin{array}{r}\text { Budget } \\
1999 / 2000\end{array}$ \\
\hline \multicolumn{8}{|c|}{ Manufacturing } \\
\hline BTMC & -1168.70 & -1340.00 & -1632.50 & -927.20 & -380.00 & -887.30 & -473.68 \\
\hline BJMC & -314.30 & -961.80 & -2517.10 & -2759.00 & -1975.00 & -2873.60 & -2535.00 \\
\hline BSEC & -683.60 & -645.00 & -1032.80 & $=\$ 124.30$ & -971.00 & -977.70 & 986.00 \\
\hline BSFIC & 78.00 & -377.60 & -652.80 & -392.50 & -324 & -360.00 & 570.00 \\
\hline BCIC & -754.70 & -1213.50 & -2389.70 & -671.40 & -620.00 & -1607.10 & -613.70 \\
\hline BFIDC & 10.80 & -30.00 & -17.70 & .70 .00 & 71.00 & 60.90 & 71.00 \\
\hline \multicolumn{8}{|c|}{ Electricity, Gas, Water } \\
\hline $\mathrm{PDB}$ & -4810.50 & -764.90 & -3234.40 & -1871.60 & -3434.00 & -3659.70 & -6889.90 \\
\hline DESA & -1985.50 & -1392.09 & -1442.70 & -1513.60 & -1652.00 & -1910.60 & -1276.30 \\
\hline CWASA & -25.60 & -33.06 & -19.04 & -35.18 & -24.00 & -24.36 & -24.80 \\
\hline DWASA & -20.00 & -41.60 & -33.49 & 28.50 & 63.00 & 70.70 & 69.73 \\
\hline BOGMC & 1170.00 & 1436.30 & 1260.90 & 1321.00 & 2844.00 & 1793.90 & 2398.30 \\
\hline \multicolumn{8}{|c|}{ Transport and Communication } \\
\hline BSC & -128.90 & 171.10 & 85.30 & -92.10 & 51.00 & 19.20 & 61.60 \\
\hline BWTTC & -6.60 & 17.20 & 90.20 & 70.10 & 18.00 & -159.00 & -156.70 \\
\hline CPA. & 640.80 & 924,00 & 1109.80 & 1025.00 & 641.00 & 675.90 & 614.10 \\
\hline MPA & 203.20 & 204.60 & 171.10 & 207.90 & 105.00 & 111.70 & 88.30 \\
\hline BMMAN & 631.50 & 496,00 & $-\$ 74.20$ & -582.80 & 552.00 & -370.90 & 460,60 \\
\hline BRTC & -88.40 & $-\$ 4.10$ & -46.80 & -77.70 & -49.00 & -80.00 & -134.00 \\
\hline \multicolumn{8}{|c|}{ Commercial } \\
\hline $\mathrm{BPC}$ & 1427.40 & 973.30 & -3461.10 & 1492.20 & 352.00 & 1220.60 & -146.40 \\
\hline BJC & -63.00 & -18.70 & -14.00 & 7.90 & -9.00 & 2.40 & 3.60 \\
\hline TCB & 16.40 & -153.00 & -375.00 & -21.80 & 6.00 & -5.50 & -13.20 \\
\hline \multicolumn{8}{|c|}{ Agriculture \& Fishery } \\
\hline BFDC & 31.50 & 2.10 & 20.50 & 0.00 & -13.00 & 4.20 & 11.60 \\
\hline BADC & $-117,80$ & -134.00 & -158.00 & 64.70 & -293.00 & -307.60 & -339.30 \\
\hline $\mathrm{CDA}$ & 39.30 & 37.70 & 37.90 & 19,30 & 616.00 & 31.00 & 53.80 \\
\hline RAJUK & 191.40 & 174.10 & 50.90 & 24.50 & 41.00 & 135.00 & 122.00 \\
\hline KDA & 67.50 & 42,60 & 51.90 & 53.50 & 111.00 & 79.70 & 40,30 \\
\hline RDA & 0.15 & 7.20 & 13.70 & 10.90 & 0.00 & 9,58 & 5.70 \\
\hline \multicolumn{8}{|l|}{ Services } \\
\hline $\mathrm{BFDC}$ & 2.70 & 8.50 & 2.10 & 2.40 & 12.00 & -4.30 & -1.50 \\
\hline BFFWT & 22.30 & 48.30 & 99.10 & 125.00 & 67.00 & 80.40 & 12160 \\
\hline ВТВ & -6.00 & 3.70 & 2.30 & 20.10 & & 5.20 & 2.90 \\
\hline BIWTA & -166.20 & -215.40 & -193.90 & -260.60 & -76.00 & .53 .90 & .78 .60 \\
\hline BPRC & 24.10 & 12,40 & 12.00 & 14.20 & 37.00 & 22.00 & 24.40 \\
\hline BWDB & 93.20 & 32.00 & $\$ 4.60$ & 18,30 & 0.00 & 25.80 & 26.90 \\
\hline REB & 170.00 & 245.90 & 175.00 & 200.00 & 191.00 & 220.60 & 248.40 \\
\hline BSCIC & -7.00 & -19.10 & -37.70 & -42.70 & -63.00 & -80.60 & -94.10 \\
\hline EPZA & 51.80 & 89.40 & 130.70 & 123.90 & 69.00 & 72.20 & 64.90 \\
\hline CAAB & 615.90 & 717.10 & 701.80 & 769.10 & 0.00 & 658.10 & 614.90 \\
\hline BHE & 2.10 & 0.80 & 0.00 & 0.00 & 0.00 & 0.00 & 0.00 \\
\hline BSB & 0.00 & 0.00 & $0 . \infty 0$ & 0.00 & -2.00 & 0.00 & -2.06 \\
\hline Total & -4856.90 & -1756.66 & -13816.83 & -4854.88 & -4038.00 & -8070.72 & -8096.31 \\
\hline
\end{tabular}

Soutce: Ministry of Finance, Autonomous Bodies Wing and Finance Divisior, and staff estimates. 
Table 20. Bangladesh: Monetary Survey, 1996/97-1999/2000

\begin{tabular}{|c|c|c|c|c|c|c|c|c|c|}
\hline & \multirow{3}{*}{$1996 / 97$} & \multirow{3}{*}{$1097 / 98$} & \multicolumn{5}{|c|}{$1998 / 99$} & \multicolumn{2}{|c|}{$1999 / 2000$} \\
\hline & & & \multirow[t]{2}{*}{ Sept. } & \multirow[t]{2}{*}{ Dec. } & \multirow[t]{2}{*}{ Mar. } & \multicolumn{2}{|c|}{ Jun. } & \multirow[t]{2}{*}{ Sept. } & \multirow[t]{2}{*}{ Oct. } \\
\hline & & & & & & \multicolumn{2}{|c|}{ Program } & & \\
\hline & \multicolumn{9}{|c|}{ (In billions of taka; end of period) } \\
\hline Deposit money banks & 15.3 & 14.0 & 10.4 & 17.4 & 11.7 & 65.3 & 16.9 & 14.3 & 16.5 \\
\hline Net domestic assets & 440.8 & 490.8 & 494.0 & 520.6 & 539.8 & 555.9 & 566.2 & 573.8 & 578.0 \\
\hline Domestic credit & 494.0 & 556.4 & 562.2 & 590.9 & 615.3 & 633.9 & 629.1 & 636.9 & 645.8 \\
\hline Public sector & 138.9 & 155.2 & 155.5 & 158.4 & 176.4 & 173.4 & 172.7 & 182.6 & 187.8 \\
\hline Govermment (net) & 80.2 & 92.7 & 94.1 & 97.4 & 114.0 & 107.7 & 112.5 & 122.4 & 127.9 \\
\hline Broad money & 506.3 & 558.7 & 563.8 & 597.6 & 599.7 & 628.5 & 630.3 & 646.5 & 653.6 \\
\hline Currency in circulation & 75.7 & 81.5 & 83.3 & 80.8 & 90.4 & 84.9 & 86.9 & 90.0 & 90.0 \\
\hline \multirow[t]{2}{*}{ Deposits } & 430.5 & 477.2 & 480.5 & 516.8 & 509.3 & 543.6 & 543.4 & 556.5 & 563.6 \\
\hline & \multicolumn{9}{|c|}{ (Annual percentage change) } \\
\hline Net Forejgn Assets lf & -0.4 & 0.5 & 1.0 & 2.4 & -0.8 & 0.8 & -0.7 & 4.3 & 7.4 \\
\hline Net domestic assets & 13.2 & 11.3 & 10.7 & 10.3 & 15.8 & 13.3 & 15.4 & 16.2 & 17.1 \\
\hline Domestic credit & 13.7 & 12.6 & 10.4 & 13.0 & 16.9 & 13.9 & 13.1 & 13.3 & 13.4 \\
\hline Public & 17.8 & 11.7 & 12.4 & 14.0 & 24.2 & 11.8 & 11.3 & 17.4 & 19.7 \\
\hline
\end{tabular}

Sources: Data provided by the Bangladesh Bank; and Fund staff estimates.

$1 /$ Contribution to broad money growth.

CInternational Monetary Fund. Not for Redistribution 
Table 21. Bangladesh: Accounts of the Monetary Authorities, 1994/95-1998/99

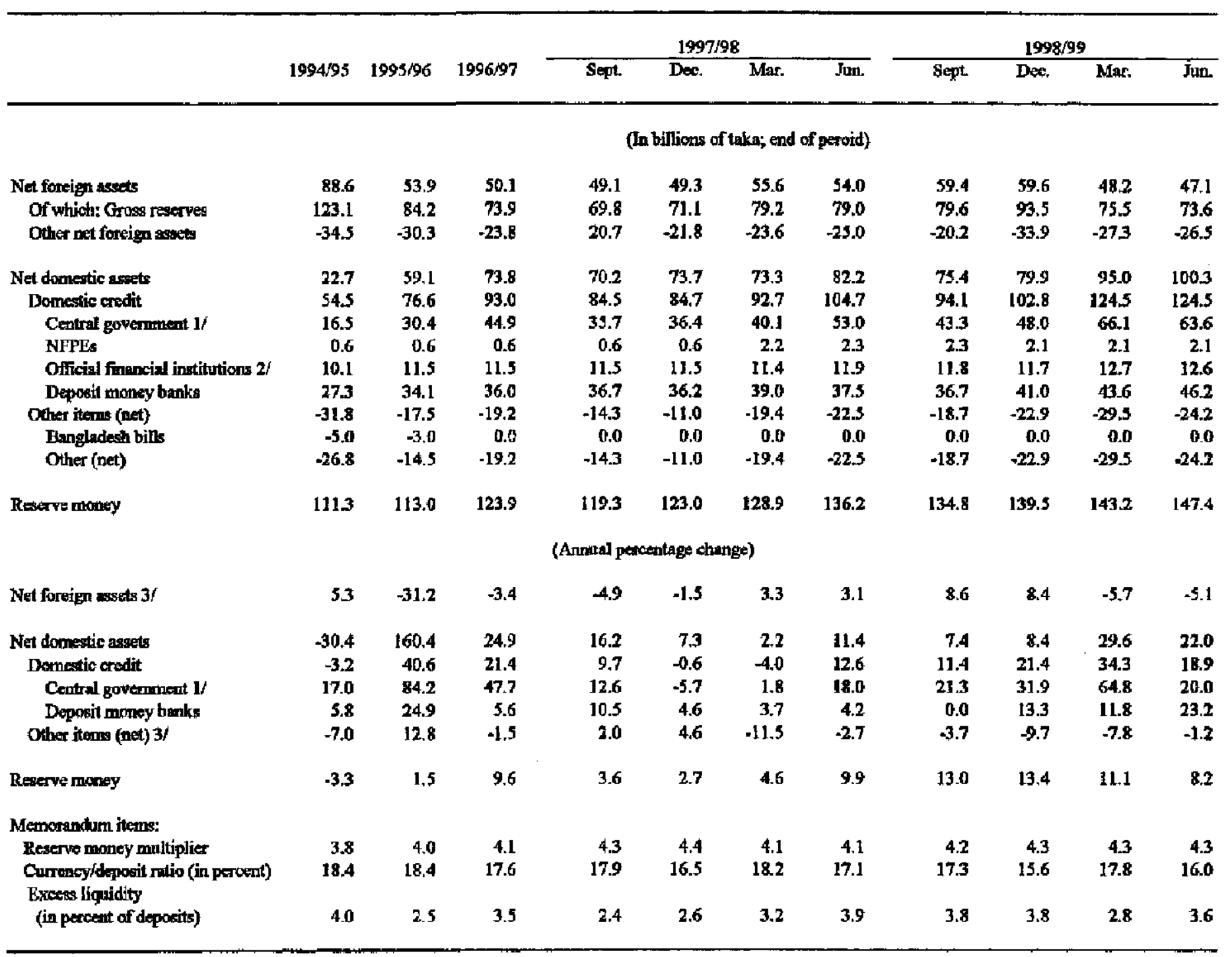

Source: Data provided by the Bangladesh Bank.

1/ heludes net claims on railways, post office, and tetephone and telegraph.

2/Inchudes mainly the lavestment Corporation of Banghadesh and the Bangladesh House Building Finance Corporation.

3/Contribation to reserve money growth.

(C)International Monetary Fund. Not for Redistribution 
Table 22. Bangladesh: Reserves of Deposit Money Banks, 1994/95-1998/99

\begin{tabular}{|c|c|c|c|c|c|c|c|c|c|c|c|}
\hline & \multirow[b]{2}{*}{$1994 / 95$} & \multirow[b]{2}{*}{$1995 / 96$} & \multirow[b]{2}{*}{$1996 / 97$} & \multicolumn{4}{|c|}{$1997 / 98$} & \multicolumn{4}{|c|}{$1998 / 99$} \\
\hline & & & & Sept. & Dec. & Sept. & Jun. & Sept. & Dec. & Mar. & Junt. \\
\hline & \multicolumn{11}{|c|}{ (lat billions of taks; end of period) } \\
\hline Required liquid assets $1 /$ & 73.0 & 80.0 & 88.8 & 88.0 & 94.4 & 92.1 & 97.5 & 98.8 & 99.8 & 104.6 & 104.7 \\
\hline NCBs $2 \%$ & 49.2 & 54.2 & 58.8 & 58.8 & 63.0 & 61.1 & 64.5 & 64.6 & 62.6 & 68.6 & 67.7 \\
\hline Private baniks & 19.7 & 20.9 & 23.6 & 22,6 & 24.5 & 23.8 & 25.3 & 25.8 & 28.6 & 27.4 & 28.1 \\
\hline Foreign banks & 4.1 & 4.9 & 6.4 & 6.6 & 6.9 & 7.2 & 7.7 & 8.4 & 8.5 & 8.7 & 9.0 \\
\hline Actural liquid ansets & 96.7 & 93.4 & 105.8 & 104.1 & 114.7 & 107.5 & 117.1 & 128.0 & 141.7 & 129.7 & 138.2 \\
\hline $\operatorname{NCBs} 2 /$ & 64.9 & 59.6 & 63.8 & 63.3 & 71.4 & 65.2 & 72.5 & 76.8 & 85.7 & 74.0 & 80.0 \\
\hline Private banks & 24.9 & 26.5 & 30.1 & 29.1 & 32.5 & 30.8 & 33.0 & 34.6 & 38.8 & 362 & 39.8 \\
\hline Foreign banks & 6.9 & 7.3 & 11.9 & 11.7 & 10.8 & 11.5 & 11.6 & 16,6 & 17.2 & 19.6 & 183 \\
\hline Excess liqukidity & 23.7 & 13.4 & 17.0 & 16.1 & 20.3 & 15.4 & 19.6 & 29.2 & 42.0 & 25,1 & 33.4 \\
\hline NCBs $2 /$ & 15.7 & 5.4 & 5.0 & 4.5 & 8.4 & 4.2 & 8.0 & 12.2 & 23.2 & 5,4 & 12.4 \\
\hline Private banks & 52 & 5.6 & 6.5 & 6.6 & 8.0 & 6.9 & 7.7 & 8.8 & 10.1 & 8.8 & 11.7 \\
\hline Foreign banks & 2.8 & 2.4 & 5.5 & 5.0 & 3.9 & 4.3 & 3.9 & 8.2 & 8.7 & 10.9 & 9.3 \\
\hline Total deposits & 373.1 & 409,6 & 454.8 & 451.2 & 484.5 & 472.7 & 500.0 & 507.8 & 545.7 & 535.5 & 567.7 \\
\hline NCBs 2 & 245.9 & 271.3 & 293.9 & 294.3 & 315.3 & 305.4 & 322.4 & 323.0 & 351.7 & 337.9 & 354.9 \\
\hline Private banks & 106.7 & 113.7 & 128.9 & 123.9 & 134.6 & 131.0 & 139.2 & 142.8 & 150.6 & 153.2 & 165.8 \\
\hline \multirow[t]{2}{*}{ Foreign banks } & 20.5 & 24.8 & 32.0 & 33.0 & 34.6 & 36.3 & 38,4 & 42.0 & 43.4 & 44.4 & 47.1 \\
\hline & \multicolumn{11}{|c|}{ (In percent of respective deposits) } \\
\hline \multicolumn{12}{|l|}{ Memorandum items: } \\
\hline Excess liquidity & 6.4 & 3.3 & 3.7 & 3.6 & 4.2 & 3.3 & 3.9 & 5.8 & 7.7 & 4.7 & 5.9 \\
\hline NCBs $2 /$ & 6.4 & 2.0 & 1.7 & 1.5 & 2.7 & 1.4 & 2.5 & 3.8 & 6.6 & 1.6 & 3.5 \\
\hline Private banks & 4.9 & 4.9 & 5.0 & 5.3 & 5.9 & 5.3 & 5.5 & 6.2 & 6.7 & 5.8 & 7.1 \\
\hline Foreign banks & 13.7 & 9.7 & 17.2 & 15.2 & 113 & 11.8 & 10.2 & 19.5 & 20.0 & 24.6 & 19.8 \\
\hline
\end{tabular}

Source: Bangladesh Bank, Banking Control Department.

U/ Liquid asset requirements against all deposits, including government and interbank deposits, were 25 percent from October 29, 1987; 24 percent from April 4, 1991; 23 percent from Aptii 25, 1991; 22 percent from December 5, 1991; 21 percent from Aprit 1, 1992; and 20 percent from May 28, 1992 to the present. Specialized banks are excinded from the requirement, while the requirement for the Islami Bank, Al Baraka Bank, Al Arafah Islami Bank and Social Investment Bank Led. is 10 percent of deposits. 2/ Nationalized commercial banks. 
Table 23. Bangladesh: Interest Rate Structure of the Banking Sector, 1994/95-1998/99

(In percent per annum; end of period)

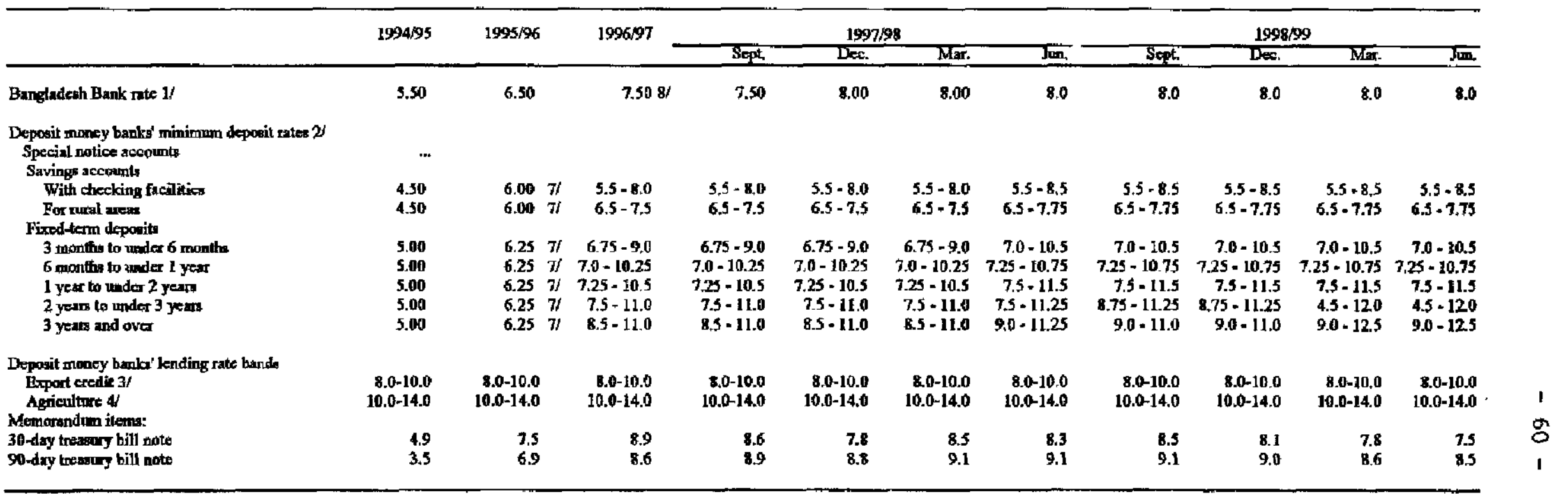

Source: Bangladeah Bank, Banking Regulation and Policy Department.

1/ Rfiective April 1, 1992, Bapgladeah Bank removed all ceilings on depasit rates and all floons and ceilinga on all lending rates with the excoption of the rates applicable to the expart, agricalture, and imall cottage induatries sectors. The deposit ratee qunted se the floor rates for the various maturitiea.

2/Deposit maney banks abo pay inberst, which varies monthly, on nonresident fortign cerreancy deposit accounts.

3 Fron September 1985 to December 1989, 2 ralo of 7 percent was applied to a small number of newily emergitig nontraditional export itema. This special nate was abolished effective January 1, 1990.

$4 /$ halades servicu charge of 4 persent.

5/ Loums given to the less developed areas, including Chittageng Fill Tracts, in parteunince of weiveconomic objectives.

6/ Effective Oetober 31, 1996

W/ hitcrost rate controh on deposits were abolished with effect from February 19, 1997.

8/ Effective May 19, 1997. 
Table 24. Bangladesh: Interest Rate Structure of Nonbank Financial Institutions and Government Debt, 1994/95-1998/99

(In percent per annum)

\begin{tabular}{|c|c|c|c|c|c|c|c|c|c|c|c|}
\hline & \multirow{2}{*}{$1994 / 95$} & \multirow{2}{*}{$1995 / 96$} & \multirow{2}{*}{$1996 / 97$} & \multicolumn{3}{|c|}{$1997 / 98$} & \multirow[b]{2}{*}{ Jun. } & \multicolumn{4}{|c|}{ 1998/99 } \\
\hline & & & & Sep. & Dec. & Mar. & & Sept. & Des. & Mar. & J酸 \\
\hline \multicolumn{12}{|l|}{$\begin{array}{l}\text { Interest rates on deposits with } \\
\text { Post Office } \mathrm{S} \text { sings Bank }\end{array}$} \\
\hline $\begin{array}{l}\text { Ordinary account } \\
\text { Fixed deposit account }\end{array}$ & 8.0 & 8.0 & 8.5 & 8.5 & 8.5 & 8.5 & 8.5 & 8.5 & 8.5 & 8.5 & 8.5 \\
\hline For one year & 10.0 & 9.5 & 10.5 & 10.5 & 10.5 & 10.5 & 10.5 & 10.5 & 10.5 & 10.5 & 10.5 \\
\hline For two years & 11.0 & 10.5 & 11.5 & 11.5 & 11.5 & 11.5 & 11.5 & 11.5 & 115 & 11.5 & 11.5 \\
\hline For three years & 12.0 & 11,5 & 12.5 & 12.5 & 12.5 & 12.5 & 12.5 & 12.5 & 12.5 & 12.5 & 12.5 \\
\hline $\begin{array}{l}\text { Interest rates on government ways and } \\
\text { means advancess }\end{array}$ & 5.0 & 5.5 & 6.5 & 6.5 & 6.5 & 6.5 & 6.5 & 6.5 & 6.5 & 6.5 & 6.5 \\
\hline \multicolumn{12}{|l|}{ Interest rates on selected savings instruments } \\
\hline 8-year Defense Savings Certificates & 17.0 & 16.5 & 17.8 & 17.8 & 17.8 & 17.8 & 17.8 & 17.8 & 17.8 & 17.8 & 17.8 \\
\hline 5-year Bangladesh Savings Certificates & 14.0 & 13.5 & 14.5 & 14.5 & 14.5 & 14.5 & 14.5 & 14.5 & 14.5 & 14.5 & 14.5 \\
\hline 5-year Wage Eamers' Development Bonds & 15.8 & 14.2 & 15.8 & 15.8 & 15.8 & 15.8 & 15.8 & 15.8 & 15.8 & 15.8 & 15.8 \\
\hline
\end{tabular}

Source: Bangladesk Bank, Statistics Department and Currency Management and Accounts Department. 
Table 25. Bangladesh: Deposit Money Barks' Credit by Economic Sector, 1994/95-1998/99 1/

(In billions of taka; end of period)

\begin{tabular}{|c|c|c|c|c|c|c|c|c|c|c|c|}
\hline & \multirow[t]{2}{*}{$1994 / 95$} & \multirow[t]{2}{*}{$1995 / 46$} & \multirow[t]{2}{*}{$1996 / 97$} & \multicolumn{3}{|c|}{$1997 / 98$} & \multirow[b]{2}{*}{ Jun. } & \multicolumn{4}{|c|}{$1998 / 99$} \\
\hline & & & & Sep. & Dec. & Mar. & & $\overline{\text { Sept. }}$ & Dec. & Mar. & Jun. \\
\hline Total credit & 373.2 & 425.0 & 472.0 & 496.5 & 514.2 & 510.6 & $\$ 31.00$ & 547.90 & $\$ 79.20$ & 579.80 & 599.60 \\
\hline Advanoes & 283.3 & 334.8 & 372.8 & 389.1 & 402.9 & 403.1 & 420.70 & 425.80 & 449.80 & 456,90 & 474.80 \\
\hline Agriculture & 58.9 & 64.3 & 67.4 & 663 & 664 & 68.3 & 69.9 & 71.7 & 74.8 & $\ldots$ & $\ldots$ \\
\hline Public & 6.1 & 5.0 & 5.3 & 5.6 & 5.9 & 6.5 & 6.2 & 6.9 & 7.4 & $\ldots$ & $\ldots$ \\
\hline Private & 52.8 & 59.3 & 62.1 & 60.7 & 60.5 & 62.2 & 63.7 & 64.5 & 67.4 & $\ldots$ & $\ldots$ \\
\hline \multicolumn{12}{|l|}{ Of which } \\
\hline Crop finance & 54.5 & $\$ 9.7$ & 62.8 & 61.6 & 61.7 & 62.0 & 63.9 & 64.3 & 67.4 & $\ldots$ & '... \\
\hline Public & 6.0 & 5.0 & 5.3 & 5.4 & 5.7 & 5.9 & 5.8 & 5.8 & 6.2 & $\ldots$ & $\ldots$ \\
\hline Private & 48.5 & 54.7 & 57.5 & 56.2 & 56.0 & 56.1 & 58.1 & 58.5 & 61.2 & $\begin{array}{l}\cdots \\
\cdots\end{array}$ & $\cdots$ \\
\hline Manufacturing & 1173 & 136.3 & 161.2 & 164.1 & 172.6 & 185.5 & 192.3 & 196.3 & $2 \times 3.6$ & $\ldots$ & $\ldots$ \\
\hline Public & 24.1 & 21.9 & 28.6 & 29.6 & 32.4 & 29.9 & 28.6 & 30.4 & 32.3 & $\ldots$ & $\ldots$ \\
\hline Private & 932 & 114.4 & 132.6 & 134.5 & 140.2 & 155.6 & 163.7 & 165.4 & 71.3 & $\ldots$ & $\ldots$ \\
\hline Wholesale and retail & 56.3 & 63.6 & 68.9 & 66.7 & 69.3 & 67.2 & 69.3 & 70.9 & 77.2 & $\begin{array}{l}\cdots \\
\cdots\end{array}$ & $\begin{array}{l}\cdots \\
\ldots\end{array}$ \\
\hline Ppablic & 5.4 & 1.1 & 2.1 & 0.3 & 0.3 & 0.1 & 0.3 & 0.9 & 1.0 & $\begin{array}{l}\cdots \\
\cdots\end{array}$ & $\cdots$ \\
\hline Private & 50.9 & 62.5 & 66.8 & 66.4 & 69.0 & 67.1 & 690 & 70.8 & 76.2 & $\begin{array}{l}\cdots \\
\ldots\end{array}$ & $\cdots$ \\
\hline Transportation & 5.1 & 5.3 & 6.6 & 6.8 & 6.5 & 8.5 & 9.4 & 9.1 & 7.5 & $\begin{array}{l}\cdots \\
\ldots\end{array}$ & $\cdots$ \\
\hline Public & 0.7 & 0.8 & 1.5 & 0.6 & 1.0 & 1.7 & 1.7 & 1.9 & 0.4 & $\cdots$ & $\cdots$ \\
\hline Private & 4.4 & 4.5 & 5.1 & 6.2 & 5.5 & 6.8 & 7.7 & 7.2 & 6.7 & $\ldots$ & $\ldots$ \\
\hline Community & 22.4 & 28.8 & 31.9 & 34.6 & 35.8 & 37.5 & 41.3 & 43.3 & 44.3 & $\cdots$ & $\cdots$ \\
\hline Public & 1.4 & 1.4 & 1.6 & 2.8 & 2.1 & 1.6 & 1.9 & 1.5 & 1.9 & $\ldots$ & $\ldots$ \\
\hline Private & 21.0 & 27.4 & 30.3 & 31.8 & 33.7 & 35.9 & 39.4 & 41.8 & 42.4 & $\ldots$ & $\cdots$ \\
\hline Other & 23.3 & 36.5 & 36.8 & 50.6 & $\$ 2.3$ & 36.1 & 38.5 & 34.5 & 42.8 & $\cdots$ & $\ldots$ \\
\hline Public & 7.0 & 8.0 & 2.5 & 4.8 & 2.1 & 4.2 & 6.8 & 2.8 & 1.7 & $\begin{array}{l}\cdots \\
\cdots\end{array}$ & $\cdots$ \\
\hline Private & 16.3 & 28.5 & 34.3 & 45.8 & 50.2 & 31.9 & 31.7 & 31.7 & 41.1 & $\cdots$ & $\cdots$ \\
\hline Internal bills & 11.2 & 12.3 & 16.8 & 18.4 & 18,1 & 18.6 & 20.1 & 19.8 & 22.0 & 20.6 & 20.4 \\
\hline Public & 0.9 & 0.4 & 1.7 & 2.0 & 1.2 & 0.6 & 0.7 & 0.5 & 0.9 & 0.8 & 1.0 \\
\hline Grovernment & 0.4 & 0.2 & 0.3 & 0.2 & 0.2 & 0.2 & 0.3 & 0.2 & 0.3 & 0.4 & 0.6 \\
\hline Other & 0.5 & 0.2 & 1.4 & 1.8 & 1.0 & 0.4 & 0.4 & 0.3 & 0.6 & 0.4 & 0.4 \\
\hline Private & 10.3 & 11.9 & 15.1 & 16.4 & 16.9 & 18.0 & 19.4 & 193 & 21.1 & 19.8 & 19.4 \\
\hline Investment & 78.7 & 77.9 & 82.4 & 89.0 & 93.2 & 88.9 & 90.2 & 102.3 & 107.4 & 102.3 & 104.4 \\
\hline Public & 70.7 & 69.5 & 73.8 & 80.3 & 85,4 & 82.2 & 53.8 & 96.0 & 101.2 & 94.7 & 96.3 \\
\hline Government 2 & 61.9 & 61.5 & 66.3 & 72.8 & 77.6 & 74.5 & 76.3 & 53.6 & 93.7 & 87.4 & 89.3 \\
\hline Other $3{ }^{\prime}$ & 8.8 & 8.0 & 7.5 & 7.5 & 7.8 & 7.7 & 7.5 & 7.4 & 7.5 & 7.3 & 7.0 \\
\hline Private & 8.0 & 8.4 & 8.6 & 8.7 & 7.8 & 6.7 & 6.4 & 63 & 6.2 & 7.6 & 8.1 \\
\hline
\end{tabular}

Source: Bangtadesh Bank, Statistics Department.

1/ This table is not fully consistent with the nonetary survey owing to coverage and timing differences.

$2 /$ Inciudes government securities and treasury bills.

3/Includes House Building Finance Corporation and Investment Corporation of Bangladesh.

(C)International Monetary Fund. Not for Redistribution 
Table 26. Bangladesh: Financial System, June 1999

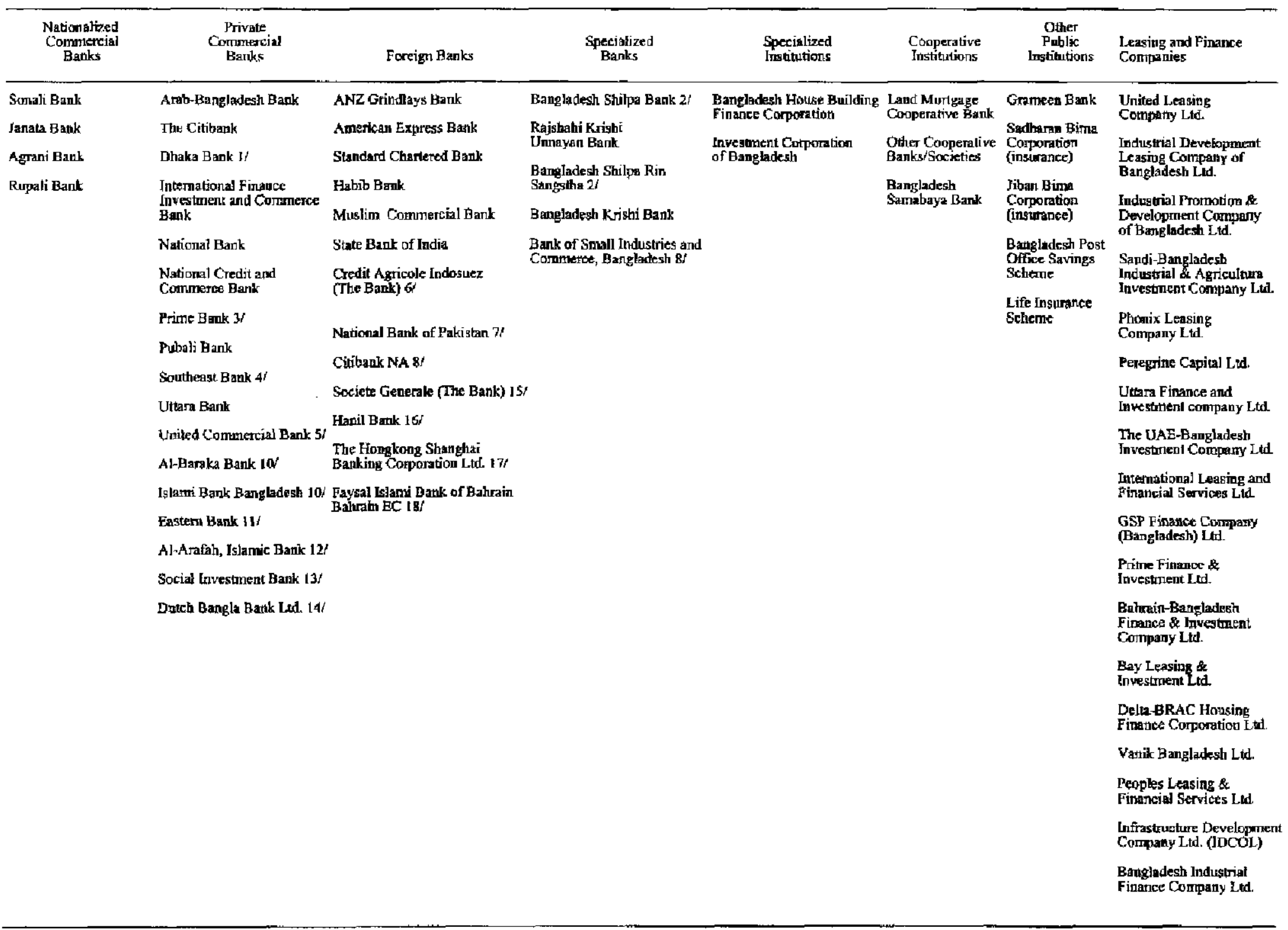

Source: Bangladesh Bank, Banking Connol Department.

1) Effective July 5, 1995.

2/ Bangladesh Shilpa Rin Sangstha was converted inw a specialized bank effective February 9. 1993.

3. Effective Apnl 17, 1995

4/ Effective May 25,1995

5/ Effective September 21, 1994 . Fommer Bangue Indostuez was converted into Credil Agricole Indosuez (The Bank) effective Novernber 18, 1994.

(g) Effective Jume 24, 1995

97. Effective July 8, 1995

lov Operates according to sslamic banking practices.
11 Porner Bank of Credin and Commerce Inkemational, Ltd. was converled intw Eastem Bank, Ltd. effective August 16, 1992. Effective September 25. 1995.

14 Effective November 22,

20/ Efeective August 10, 1997.

21/ Effective June 2, 1999.

22) Etreetive Navember 1996

14. Efective Juthe 3, 1996.

16/ Effective Stptember 21, 1996.

7) ETrective December 3,1996 .

18/ Efrective August 10, 1997.
$19 /$ Entective Juthe $2,1999$.

(C) International Monetary Fund. Not for Redistribution 
Table 27. Bangladesh: Agricultural Credit Disbursement and Recovery, 1994/95-1998/99 I/

(In billions of taka)

\begin{tabular}{|c|c|c|c|c|c|}
\hline & $1994 / 95$ & $1995 / 96$ & $1996 / 97$ & $1997 / 98$ & $1998 / 99$ \\
\hline Ovendue at beginning of period & 42.04 & 44.91 & 49.20 & 53.13 & 54.89 \\
\hline Current amount due & 13.72 & 4.29 & 3.93 & 1.76 & -0.98 \\
\hline Total amount due & 55.76 & 49.20 & 53.13 & 54.89 & 53.91 \\
\hline Amount recovered & 10.97 & 12.73 & 15.94 & 16.99 & 19.16 \\
\hline Oross disbursements & 14.80 & 14.82 & 15.17 & 16,43 & 30.06 \\
\hline Net disbursements & 3.83 & 2.09 & -0.77 & -0.56 & 10.90 \\
\hline Outstanding credit at & 70.69 & 77.69 & 82.56 & 85.15 & 96.96 \\
\hline Change in outstanding credit & 8.47 & 7.00 & 4.87 & 2.59 & 11.81 \\
\hline Implied interest capitalization & 4.64 & 4.91 & 5.64 & 3.15 & 0.91 \\
\hline \multicolumn{6}{|l|}{ Proportion of recovery to: } \\
\hline Gross disbursements & 74.1 & 85.9 & 105.1 & 103.4 & 63.7 \\
\hline Total amount duse & 19.7 & 259 & 30.0 & 31.0 & 35.5 \\
\hline Current amount due & 80.0 & 296.7 & 405.6 & 965.3 & 1955.1 \\
\hline Growth in outstanding credit & 13.6 & 9.9 & 6.3 & 3.1 & 13.9 \\
\hline $\begin{array}{l}\text { Overdue amounts/outstanding } \\
\text { credit } 2 /\end{array}$ & 67.6 & 63.5 & 63.3 & 64.4 & 64.5 \\
\hline
\end{tabular}

Sources: Bangladesh Bank, Agricultural Credit Department; and staff estimates.

1/Includes operations of the nationalized commercial banks and the Bangledesh Krishi Bank, Rajshahi Krishi Unnayan Bank, Bangladesh Samabaya Bank, Ltd, and Bangladesh Rural Development Board. $2 /$ Ratio of overcue amounts at the beginning of the period to credit outstanding at end of the previous perind 
Table 28. Bangladesh: Industrial Loan Recovery by Bangladesh Shilpa Bank, 1994/95-1998/99

\section{$1994 / 95 \quad 1995 / 96 \quad 1996 / 97 \quad 1997 / 98 \quad 1998 / 99$}

Overdue at beginning of period

$\begin{array}{lllll}7,504 & 8,638 & 9,316 & 10,367 & 11,537\end{array}$

Principal due in current period

649

590

726

901

1,483

Total due

8,153

9,228

$10,042 \quad 11,268$

13,019

Amount recovered

637

488

609

779

653

Reschedulings, adjustments, and transfers

220

338

288

511

1,328

Accrued interest 1/

1,342

914

$1,222 \quad 2,090$

1,079

Overdue at end of period

$$
8,638
$$

9,316

10,367

11,536

11,545

Gross disbursements

647

1,132

203

961

Total outstanding credit

15,608

16,586

$17,501 \quad 19,439$

19,866

(Percent)

Memorandum items:

Amount recovered/total due

Total overdue/outstanding

credit (end of period)

7.8

5.3

6.1

6.9

5.0

55.3

56.2

59.2

59.3

58.1

Source: Bangladesh Shilpa Bank.

1/ Including write-offs and waived and rescheduled interest. 
Table 29. Bangladesh: Summary Perfonnance Indicators in the Banking System, 1994-99

(In percent)

\begin{tabular}{|c|c|c|c|c|c|c|}
\hline & $\begin{array}{l}1994 \\
\text { Dec. }\end{array}$ & $\begin{array}{l}1995 \\
\text { Dec. }\end{array}$ & $\begin{array}{l}1996 \\
\text { Dec. }\end{array}$ & $\begin{array}{l}1997 \\
\text { Der. }\end{array}$ & $\begin{array}{l}1998 \\
\text { Dec. }\end{array}$ & $\begin{array}{l}1999 \\
\text { June }\end{array}$ \\
\hline Classified loans by group of bank $1 /$ & 34.8 & 32.0 & 31.5 & 32.7 & 35.4 & 38.3 \\
\hline Domestic barks & 36.3 & 33.9 & 33.3 & 34.8 & 37.7 & 40.7 \\
\hline Nationalized commercial banks & 32.1 & 31.0 & 32.6 & 36.6 & 40.4 & 47.0 \\
\hline Private domestic banks & 44.5 & 39.4 & 34.8 & $3] .4$ & 32.7 & 29.0 \\
\hline Foreign banks & 8.8 & 5.4 & 4.7 & 3.4 & 4.1 & 4.2 \\
\hline Memorandum item: Specialized development banks & $\cdots$ & $\cdots$ & 50.9 & 65.7 & 66.7 & 67.9 \\
\hline Total classified loans by category $1 / 3 /$ & 34.8 & 32.0 & 31.5 & 32.7 & 35.4 & 38.3 \\
\hline Substandard $2 /$ & 19.2 & 13.1 & 13.4 & 10.6 & 5.2 & 8.0 \\
\hline Doubtfin $2 /$ & 17,6 & 12.4 & 12.3 & 15.7 & 8.2 & 11.7 \\
\hline Bad 2/ & 58.6 & 69.8 & 74.3 & 73.8 & 86.7 & 80.3 \\
\hline Loan market shares $1 /$ & 100.0 & 100.0 & 100.0 & 100.0 & 100.0 & 100.0 \\
\hline Domestic banks & 94.6 & 93.6 & 93.7 & 93.4 & 93.1 & 93.3 \\
\hline Nationalized commercial banks & 62.7 & 61.9 & 62.1 & 61.5 & 60.7 & 60.8 \\
\hline Private domestic barks. & 32.0 & 31.7 & 31.6 & 31.9 & 32.4 & 32.5 \\
\hline Foreign banks & 5.4 & 6.4 & 6.3 & 6.6 & 6.9 & 6.7 \\
\hline Actual provisioning in percent of required provisioning & 60.3 & 48.3 & 539 & 48.6 & 44.2 & 42.8 \\
\hline Domestic banks & 59.4 & 47.0 & 52.8 & 47.4 & 43.0 & $4 \nmid .8$ \\
\hline Nationalized commercial banks & 67.0 & 47.2 & 50.0 & 45.2 & 38.5 & 36.2 \\
\hline Private domestic banks & 45.8 & 46.6 & 58.3 & 52.2 & 54.4 & 56.8 \\
\hline Foreign banks & 103.2 & 112.5 & 122.4 & 137.5 & 132.4 & 128.3 \\
\hline
\end{tabular}

Source: Banking Regulation and Palicy Department, Bangladesh Bank.

I/ In percent of total loans.

$2 f$ In percent of classified loans.

3/ Includes overdue agriculture short-term loans of 4.6 and 4.8 percent of all classified loans in 1994 and 1995, respectively,

4/ Adjusted to exclude interest suspense and in percent of total loans excluding interest suspense. 


$$
-67-
$$

Table 30. Bangladesh: Commercial Bank Loan Classification and Provisioning, 1994-1999 (in billions of taka)

\begin{tabular}{|c|c|c|c|c|c|c|}
\hline & 1994 & 1995 & 1496 & 1997 & 1998 & 1999 \\
\hline Total commercial bank loans 1 , & 262.9 & 310.3 & 351.0 & 395.8 & 438.7 & 461.1 \\
\hline Dometic banks & 248.9 & 290.5 & 328.8 & 369.6 & 408.3 & 430.1 \\
\hline Nationalized commeroial banks & 164.7 & 192.1 & 217.9 & 243.5 & 266.4 & 280.3 \\
\hline Private domestid banks & 84.0 & 98.5 & 110.9 & 126.1 & 141.9 & 149.8 \\
\hline Fortign banks & 14.1 & 19.8 & 22.2 & 262 & 30.4 & 31.0 \\
\hline Total including spectalizae banks & $\ldots$ & $\ldots$ & 435.0 & 462.3 & 527.3 & 550.5 \\
\hline Specializad development banks 2 & $\ldots$ & $\ldots$ & 84.0 & 66.5 & 88.7 & 89.4 \\
\hline Total classified loan by nector $3 /$ & 91.6 & 99.4 & 110.5 & 129.6 & 155.2 & 176.4 \\
\hline Domestio banks & 90.3 & 98.4 & 109,5 & 128.7 & 154.0 & 175.1 \\
\hline Nationalized commeroial banks & 52.9 & 59.5 & 70.9 & 89.1 & 107.6 & 131.7 \\
\hline Private domestid bands & 37.4 & 38.8 & 38.6 & 39.6 & 46.4 & 43.4 \\
\hline Forreign banks & 1.2 & 1.1 & 1.0 & 0.9 & 1.3 & 1.3 \\
\hline Total including speciailzee banks & $\ldots$ & $\ldots$ & 153.3 & $\mathbf{1 7 3 . 3}$ & 214.4 & 237.1 \\
\hline Spectalzed development barks 2 & $\ldots$ & $\ldots$ & 42.8 & 43.7 & 59.1 & 60.7 \\
\hline Total classified loans by cutegory $3 /$ & 91.6 & 99.4 & 110.5 & 129.6 & 214,4 & 237.1 \\
\hline Substandard 4/ & 17.6 & 13.0 & 14.8 & 13.7 & 9.1 & 15.8 \\
\hline Doubtfil 4 & 16.1 & 12.3 & 13.6 & 20.3 & 15.5 & 23,9 \\
\hline $\operatorname{Bad} 4$ & 53.7 & 69.4 & 82.2 & 95.6 & 189.8 & 197.4 \\
\hline Required provision & 40.7 & 48.0 & 51,7 & 603 & 72.8 & 78.6 \\
\hline Domestio banks & 39.8 & 47.2 & 50.9 & $\$ 9.5$ & 71.9 & 77.8 \\
\hline Nationafized commencial bantss & 25.9 & 30.9 & 33.6 & 40.6 & 51.4 & 56.4 \\
\hline Private domestid barks & 14.4 & 16.3 & 17.3 & 18.9 & 20.5 & 21.4 \\
\hline Foreign banks & 0.8 & 0.8 & 0.8 & 0.8 & 1.0 & 0.9 \\
\hline Total including specialize banks & $\ldots$ & $\ldots$ & 68.1 & 76.4 & 93.0 & 98.6 \\
\hline Specjalked dewelopinent banks $2 /$ & $\ldots$ & - & 16.4 & 16.1 & 20.1 & 19.9 \\
\hline Actual provision & 24.5 & 21.2 & 27.9 & 29.3 & 32.2 & 33.6 \\
\hline Domestic banks & 23.7 & 22.2 & 26.8 & 28.2 & 30.9 & 32.5 \\
\hline Nationalizod conmercial banks & 17.1 & 14.6 & 16.8 & 18.4 & 19.8 & 20.4 \\
\hline Private domeatid burls & 6.6 & 7.6 & 10.1 & 9.9 & 11.2 & 12.1 \\
\hline Forrign banks & 0.8 & 0.9 & 1.0 & 1.1 & 1.3 & 1.1 \\
\hline Total ineiuding spectalizee banks & $\ldots$ & .. & 42.0 & 43.4 & 48.7 & 50.2 \\
\hline Specialized developwent banks $2 f$ & $m$ & $\ldots$ & 14.1 & 14.1 & 16.5 & 16.5 \\
\hline Provision shortfall & 16.2 & 24.8 & 23.8 & 31.0 & $4 L .0$ & 45.2 \\
\hline Domestic bunks & 16.2 & 25.0 & 24.0 & 31.3 & 410 & 45.2 \\
\hline Nationalized commercial banks & 8.4 & 16.3 & 16.8 & 22.2 & 31.6 & 36.0 \\
\hline Private domestid banks & 7.8 & 8.7 & 7.2 & 9.0 & 9.3 & 9.2 \\
\hline Foreign baniks & 0.0 & -0.1 & -0.2 & $-0,3$ & $\ldots$ & .... \\
\hline Toval including specializee banks & $\ldots$ & $\ldots$ & 26.2 & 33.0 & 44.3 & 48.4 \\
\hline Specialized development banks & $\ldots$ & $\ldots$ & 2.3 & 2.0 & 3.6 & 3.4 \\
\hline
\end{tabular}

Saurov: Baaking Regulation and Polioy Departroent; Bangladesh Bamk.

L/ Excluding staff loans and inlcuding agriculture losins (both short-tern and medium/long-term). Bxchudes speaialized bank loans. Inicudes interest suspense, as por authorities' reporting.

2/ Includes BSB, BKB, RAKUB and BSRS, although BSRS data are inconplete. BASIC is classified here as a private commercial bank

3/ Including classified agriculture short-turm loans.

4/ Data for 1994 and 1995 exchude overdue agriculture short-term loans. Figures include interest suspense, whigh is aot allocated between catopories, in offioial figures. 
Table 31. Bangladesh: Capital Adequacy, 1996-1999

\begin{tabular}{|c|c|c|c|c|}
\hline & $\begin{array}{l}1996 \\
\text { Des. }\end{array}$ & $\begin{array}{l}1997 \\
D=0 .\end{array}$ & $\begin{array}{l}1998 \\
\text { Deo. }\end{array}$ & $\begin{array}{l}1999 \\
\text { June }\end{array}$ \\
\hline & \multicolumn{4}{|c|}{ (In billions of taka) } \\
\hline $\begin{array}{l}\text { Total hank tusets } \\
\text { Demertic commercial banles } \\
\text { NCB: } \\
\text { Specialized } \\
\text { Privats banks } \\
\text { Foreign banks }\end{array}$ & $\begin{array}{r}1,486.5 \\
1,292.7 \\
1,059.2 \\
133.7 \\
233.5 \\
60.1\end{array}$ & $\begin{array}{r}1,370.0 \\
1,368.4 \\
947.1 \\
119.1 \\
221.3 \\
82.5\end{array}$ & $\begin{array}{r}1,598.2 \\
1,314.0 \\
1,031.4 \\
187.9 \\
282.6 \\
96.3\end{array}$ & $\begin{array}{r}1,732.1 \\
1,439.3 \\
1,152.8 \\
194.1 \\
286.8 \\
98.7\end{array}$ \\
\hline 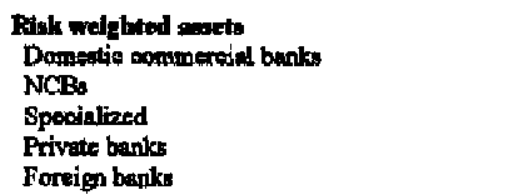 & $\begin{array}{r}434.8 \\
326.8 \\
229.8 \\
86.6 \\
97.0 \\
21.4\end{array}$ & $\begin{array}{r}463.3 \\
339.8 \\
237.0 \\
93.2 \\
102.8 \\
30.3\end{array}$ & $\begin{array}{r}510.9 \\
359.6 \\
241.6 \\
116.5 \\
118.1 \\
34.8\end{array}$ & $\begin{array}{r}576.6 \\
425.0 \\
300.0 \\
114.8 \\
124.9 \\
36.8\end{array}$ \\
\hline $\begin{array}{l}\text { Requitral capital } \\
\text { Domestic sommeroial banka } \\
\text { NCBs } \\
\text { Specialized } \\
\text { Private banks } \\
\text { Foreigo benikg }\end{array}$ & $\begin{array}{r}35.9 \\
26.8 \\
18.4 \\
7.0 \\
8.5 \\
2.1\end{array}$ & $\begin{array}{r}38.0 \\
27.7 \\
19.0 \\
7.5 \\
8.7 \\
2.9\end{array}$ & $\begin{array}{r}41.4 \\
28.9 \\
19.3 \\
9.3 \\
9.6 \\
3.2\end{array}$ & $\begin{array}{r}46.6 \\
34.1 \\
24.0 \\
9.2 \\
10.1 \\
3.3\end{array}$ \\
\hline $\begin{array}{l}\text { Actulal capttal } \\
\text { Domestio oommeroiat berks } \\
\text { NCBs } \\
\text { Speoialized } \\
\text { Private banks } \\
\text { Foreign banks }\end{array}$ & $\begin{array}{r}28.9 \\
19.7 \\
12.8 \\
5.4 \\
6.9 \\
3.8\end{array}$ & $\begin{array}{r}34.9 \\
24.3 \\
15.7 \\
5.6 \\
8.6 \\
5.0\end{array}$ & $\begin{array}{r}37.5 \\
23.5 \\
12.6 \\
8.1 \\
11.9 \\
5.9\end{array}$ & $\begin{array}{r}41.3 \\
27.7 \\
16.1 \\
8.2 \\
11.5 \\
5.4\end{array}$ \\
\hline 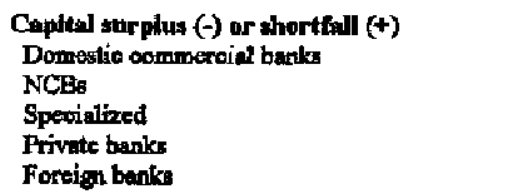 & $\begin{array}{r}7.0 \\
7.1 \\
5.6 \\
1.6 \\
1.5 \\
-1.7\end{array}$ & $\begin{array}{r}3.1 \\
3.4 \\
3.3 \\
1.9 \\
0.1 \\
-2.1\end{array}$ & $\begin{array}{r}3.9 \\
5.4 \\
6.7 \\
1.3 \\
-1.3 \\
-2.8\end{array}$ & $\begin{array}{r}5.2 \\
7.3 \\
7.9 \\
0.1 \\
-1.5 \\
-2.2\end{array}$ \\
\hline 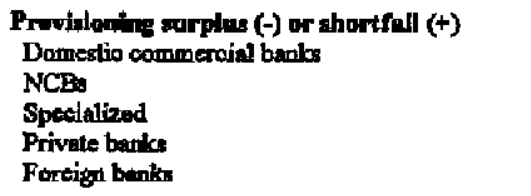 & $\begin{array}{r}26.2 \\
24.0 \\
16.8 \\
2.3 \\
7.2 \\
-0.2\end{array}$ & $\begin{array}{r}33.0 \\
31.3 \\
22.2 \\
20 \\
9.0 \\
-0.3\end{array}$ & $\begin{array}{r}44.3 \\
41.2 \\
31.6 \\
3.4 \\
9.6 \\
-0.3\end{array}$ & $\begin{array}{r}48.4 \\
45.2 \\
36.0 \\
3.4 \\
9.2 \\
-0.2\end{array}$ \\
\hline $\begin{array}{l}\text { Shortioll (+) In capibal cum prov. } \\
\text { Domealio oommerciai banka } \\
\text { NCEs } \\
\text { Speoialized } \\
\text { Private banks } \\
\text { Foreign bantss }\end{array}$ & $\begin{array}{r}33.2 \\
31.1 \\
22.4 \\
3.9 \\
8.7 \\
-1.9\end{array}$ & $\begin{array}{r}36.1 \\
34.6 \\
25.5 \\
3.9 \\
9.2 \\
-2.4 \\
\\
\text { (In }\end{array}$ & $\begin{array}{r}48.2 \\
46.6 \\
38.3 \\
4.7 \\
8.3 \\
-3.1\end{array}$ & $\begin{array}{r}53.6 \\
52.5 \\
43.9 \\
3.5 \\
7.7 \\
-2.4\end{array}$ \\
\hline 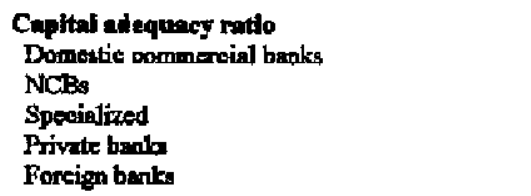 & $\begin{array}{r}6.6 \\
6.0 \\
5.6 \\
6.2 \\
7.1 \\
17.8\end{array}$ & $\begin{array}{r}7.5 \\
7.2 \\
6.6 \\
6.0 \\
8.4 \\
16.5\end{array}$ & $\begin{array}{r}7.3 \\
6.5 \\
5.2 \\
7.0 \\
9.2 \\
17.0\end{array}$ & $\begin{array}{r}7.2 \\
6.5 \\
5.4 \\
7.1 \\
9.2 \\
14.7\end{array}$ \\
\hline 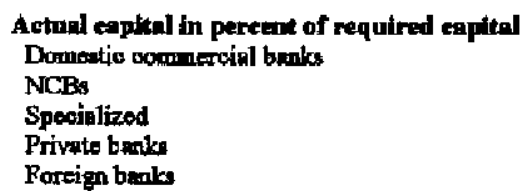 & $\begin{array}{r}80.5 \\
73.5 \\
69.6 \\
77.1 \\
81.2 \\
181.0\end{array}$ & $\begin{array}{r}91.8 \\
87.9 \\
82.8 \\
75.1 \\
98.9 \\
172.4\end{array}$ & $\begin{array}{r}90.6 \\
81.3 \\
65.3 \\
87.1 \\
113.5 \\
184.4\end{array}$ & $\begin{array}{r}88.6 \\
81.2 \\
67.1 \\
89.1 \\
113.9 \\
163.6\end{array}$ \\
\hline
\end{tabular}

Souree: DBOD, Bangladesh Bank. 
Table 32. Bengladesh: Balance of Payments 1994/95-1998/99 (In millitions of U.S. doDlas)

\begin{tabular}{|c|c|c|c|c|c|}
\hline & 199495 & 109596 & 1595197 & $1997 / 98$ & 1998.99 \\
\hline Trade bealarice & $-2 ; 361.0$ & $-2,998.6$ & $-2,743.8$ & $-2,3-78$ & -3.012 .3 \\
\hline Exparte & $3,473.0$ & $3,020.4$ & 4,418.3 & $2,172.1$ & $3,324.4$ \\
\hline Inpoute & $-3,834,0$ & $-6,881,0$ & $-7,162.1$ & $-7,5000$ & $-8,336.6$ \\
\hline Foodgrain & -1760 & -5860 & -184.0 & -369.0 & 997.0 \\
\hline Capitul poods & $-1,6880$ & $-1,918.0$ & $-1,4937.0$ & $-2,0720$ & $-2,295.9$ \\
\hline Other & $-3,670.0$ & $\$ 377.0$ & $-5,041.1$ & $-3,07900$ & $-3,035.7$ \\
\hline Net Senvices: & -95.1 & .112s & 55.9 & 225 & -45.6 \\
\hline Rosiphts & 819.3 & 808.2 & 745.0 & 797.9 & 812.2 \\
\hline Phymomit & $-\$ 14 d$ & -921.1 & -68.1 & .715 .4 & -865.8 \\
\hline Thentofer & 1,7280 & $1,758,0$ & $2,145.0$ & $2,016,8$ & $2,234.8$ \\
\hline Offinil camest tranfer & 364.0 & 320.0 & 355.0 & 2668 & 259.8 \\
\hline Private trousuan & $1,426.0$ & $1,473.0$ & $1,770.0$ & $1,750,0$ & 1,9750 \\
\hline 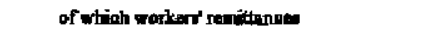 & $1,198.0$ & $1,217.0$ & $1,475.4$ & $\$, 526.0$ & 1,7060 \\
\hline & & - & & & \\
\hline 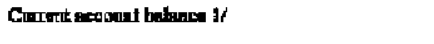 & -728.1 & $-1,316.3$ & -542.9 & .218 .9 & -873: : \\
\hline 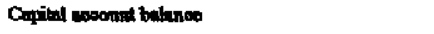 & 835.8 & 280.0 & 190.7 & 379.3 & $\sin 2$ \\
\hline 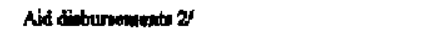 & $1,375.0$ & 1.1240 & $1,133.0$ & $1,673.0$ & $1,214.5$ \\
\hline Comumatity lows & 2060 & \$7.0 & 160 & 42.0 & $20 \$ .2$ \\
\hline Propoent aid $3 /$ & $1,269,0$ & $1,077.0$ & $1,117.0$ & $1,023.0$ & $1,009,3$ \\
\hline 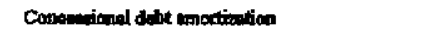 & -314.0 & -316.0 & $\$ 29.0$ & 3080 & .340 .0 \\
\hline 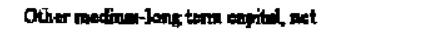 & -13.2 & 28.0 & 45.7 & -4.9 & -30.3 \\
\hline Fonvion dinuct and portfotio invewtment & mo & -140 & -1200 & $\mathbf{3 3 6} 0$ & $65 x 0$ \\
\hline 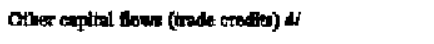 & $-2+9.0$ & -539.0 & -539.0 & .6740 & -975.0 \\
\hline Ersore and ondiontions & 1243 & 132.5 & 189.2 & -48.7 & 18.6 \\
\hline overall baltace & 202.0 & -901.0 & -160.0 & 82.1 & -171.2 \\
\hline Findurcing items & -202.0 & s01.0 & Les.0 & -82.1 & 171.2 \\
\hline Bamgloderh Benk & 2160.0 & 926.0 & 180.0 & -131.9 & 358.2 \\
\hline Aswed (-increase) & $-274,0$ & 1,0620 & 320.1 & $-14, j$ & 2009.7 \\
\hline Limbilition & 114.0 & -136.0 & -140.1 & -117.9 & 8.5 \\
\hline Fand arotit, not & $+\infty .0$ & -6.0 & .114 .0 & -107.0 & 27.0 \\
\hline 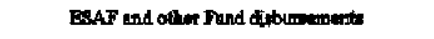 & 0.0 & 0,0 & 0.0 & 0.0 & 138.0 \\
\hline Fund ropowenter & $\$ 0.0$ & -66.0 & -114.0 & -107.0 & -111.0 \\
\hline Other, nut & -140 & -500 & -20.1 & $-10,0$ & -18.5 \\
\hline Adjuatement $\mathbf{S}$ & $1 \neq 8.0$ & 0.0 & 0.0 & d.o & 0.0 \\
\hline Coramperais tants & -72.0 & -25.0 & -17.0 & 49,4 & $\$ 7,0$ \\
\hline \multicolumn{6}{|l|}{ Memoradom itmur; } \\
\hline 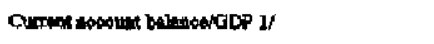 & -1.9 & -3.3 & -1.3 & $-9,6$ & -19 \\
\hline 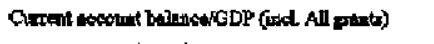 & -0.5 & -2.4 & -0.4 & 0.1 & -1.1 \\
\hline 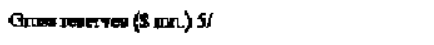 & 3,070 & 2,009 & 1,719 & 1,73 & 1,529 \\
\hline 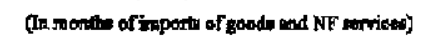 & 5.6 & 9.2 & 2.7 & 2.6 & 2.1 \\
\hline 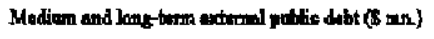 & 16,767 & 15,170 & 15,025 & 14,033 & 15,145 \\
\hline External debtoDP & $\$ 4.5$ & 37.6 & 36,6 & 33.2 & 35.0 \\
\hline Debt-wife mito 6 & 10.4 & 9.4 & 8.7 & 7.9 & 78 \\
\hline Debitervieuapt & 1.5 & 1.4 & 1.5 & L.t & 1,5 \\
\hline 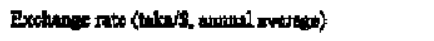 & 40.2 & 40.9 & d2.7. & 45.4 & 478 \\
\hline Nominal GDP (mar LS3) & 37,613 & 40,343 & 41,040 & 42,304 & 43,292 \\
\hline
\end{tabular}

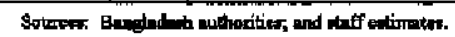

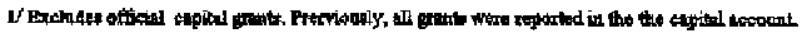

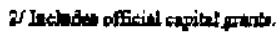

3 Inclode moneADP finuncing tord copital grane

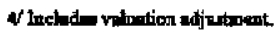

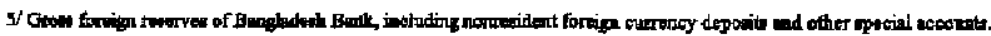

of In peceent of coment roceipt. 
Table 33. Bangladesh: Exports by Main Product Categories, 1994/95-1998/99

\begin{tabular}{|c|c|c|c|c|c|}
\hline & $1994 / 95$ & $1995 / 96$ & $1996 / 97$ & $1997 / 98$ & $\begin{array}{r}\text { Est. } \\
1998 / 99\end{array}$ \\
\hline & \multicolumn{5}{|c|}{ (In millions of U.S. dollars) } \\
\hline Raw jute & 79.0 & 90.7 & 116.0 & 107.8 & 71.8 \\
\hline Volume (millions of bales) & 1.4 & 1.4 & 1.7 & 1.8 & 1.8 \\
\hline Average unit value & 56.0 & 64.4 & 66.5 & 59.1 & 41.1 \\
\hline Jute goods (excl. carpets) & 310.0 & 324.8 & 313.3 & 278.6 & 301.9 \\
\hline Volume (000 of tons) & $\$ 39.6$ & 536.9 & 487.9 & 446.5 & 488.2 \\
\hline Average unit value & 574.5 & 605.0 & 642.2 & 624.0 & 618.5 \\
\hline Tea & 33,0 & 33.1 & 38.0 & 47.5 & 38.6 \\
\hline Volume (millions of $\mathrm{kgs}$ ) & 25.2 & 21.4 & 24.8 & 26.7 & 22.7 \\
\hline Average unit value & 1.3 & 1.5 & 1.5 & 1.8 & 1.7 \\
\hline Leather and leather products & 202.0 & 211.7 & 195.0 & 190.3 & 168.2 \\
\hline Volume (millions of square feet) & 161.7 & 155.8 & 128.6 & 127.7 & 186.9 \\
\hline Average unit value & 1.2 & 1.4 & 1.5 & 1.5 & 0.9 \\
\hline Frozen shrimps and fish & 306.0 & 313.7 & 320.0 & 293.8 & 274.3 \\
\hline Volume (rnillions of pounds) & 78.4 & 75.1 & 86.0 & 73.4 & 70.3 \\
\hline Average unit value & 3.9 & 4.2 & 3.7 & 4.0 & 3.9 \\
\hline Ready-made garments & $1,839.0$ & $1,948.8$ & $2,238.0$ & $2,843.3$ & $2,984.7$ \\
\hline Volume (million dozens) & 47.2 & 48.8 & 53.5 & 65.6 & 64.8 \\
\hline Average unit value index & 39.0 & 39.9 & 41.9 & 43.4 & 46.1 \\
\hline Knitweer and hosiery products & 393.0 & 598.3 & 763.3 & 940.3 & $1,035.4$ \\
\hline Volume (million dozens) & 15.3 & 23.2 & 27.5 & 32.6 & 36.7 \\
\hline \multirow[t]{2}{*}{ Average unit value index } & 25.7 & 25.8 & 27.7 & 28.8 & 28.2 \\
\hline & 0.64 & 0.66 & 0.68 & 0.73 & 0,76 \\
\hline Naphtha, furnace oil and bitamen & 14.0 & 10.9 & 16.5 & 10.9 & 5.3 \\
\hline Chemical Products (fertilizers) & 91.0 & 94.7 & 104.1 & 58.7 & 58.7 \\
\hline Agricultural Products & $\ldots$ & 26.0 & 0.0 & 0.0 & 0,0 \\
\hline Other exports & 206.0 & 229.6 & 312.5 & 390.0 & 374.0 \\
\hline \multirow[t]{2}{*}{ Total exports } & $3,473.0$ & $3,882.4$ & $4,418.3$ & $5,161.2$ & $5,312.9$ \\
\hline & \multicolumn{5}{|c|}{ (Annual Percentage Change) } \\
\hline \multicolumn{6}{|l|}{ Memorandum items: } \\
\hline Value & 37.1 & 11.8 & 13.8 & 17.1 & 2.9 \\
\hline Volume & 31.2 & 7.3 & 9.0 & 22.1 & 5.9 \\
\hline Unit price & 4.4 & 4.2 & 4.4 & -4.1 & -2.8 \\
\hline
\end{tabular}

Sources: Bangladesh Bark; and staff estimates. 
Table 34. Bangladesh: Imports by Main Product Categories, 1994/95-1998/99

\begin{tabular}{|c|c|c|c|c|c|}
\hline & $1994 / 95$ & $1995 / 96$ & $1996 / 97$ & $1997 / 98$ & $\begin{array}{l}\text { Est. 1/ } \\
1998 / 99\end{array}$ \\
\hline & \multicolumn{5}{|c|}{ (In millions of U.S. doliars) } \\
\hline Foodgrains & 476.0 & 586.0 & 184.0 & 369.0 & $1,031.0$ \\
\hline Rice & 220.0 & 358.0 & 28.0 & 247.0 & 680.0 \\
\hline Wheat & 256.0 & 228.0 & 156.0 & 122.0 & 351.0 \\
\hline Edible oil & 220.0 & 179.0 & 216.0 & 216.0 & 287.0 \\
\hline Oilseeds & 80.0 & 89.0 & 62.0 & 93.0 & 100.0 \\
\hline Petroleum products & 206.0 & 290.0 & 341.0 & 295.0 & 270.0 \\
\hline Crude petroleurn & 177.0 & 166.0 & 174.0 & 140.0 & 118.0 \\
\hline Cotton & 135.0 & 185.0 & 195.0 & 207.0 & 233.0 \\
\hline Staple fiber & 40.0 & 43.0 & 45.0 & 48.0 & 39.0 \\
\hline Yam & 200.0 & 296.0 & 395.0 & 327.0 & 283.0 \\
\hline Fertilizer & 142.0 & 97.0 & 150.0 & 108.0 & 120.0 \\
\hline Cement & 116.0 & 171.0 & 156.0 & 152.0 & 105.0 \\
\hline Textiles & $1,025.0$ & $1,043,0$ & $1,098,0$ & $1,264.0$ & $1,109,0$ \\
\hline Capital goods & $1,688.0$ & $1,918.0$ & $1,937.0$ & $2,072,0$ & $1,969.0$ \\
\hline Airctaft & 0.0 & 101.0 & 0.0 & 0.0 & 0.0 \\
\hline Other & $1,100.0$ & $1,450.0$ & $1,729.1$ & $2,229.0$ & $2,390.0$ \\
\hline \multirow[t]{2}{*}{ Total } & $5,834.0$ & $6,881.0$ & $7,162.1$ & $7,520.0$ & $8,054,0$ \\
\hline & \multicolumn{5}{|c|}{ (Annual Percentage Change) } \\
\hline \multicolumn{6}{|l|}{ Memorandum items: } \\
\hline Value & 392 & 17.9 & 4.1 & 5.1 & 1092 \\
\hline Volume & 33.0 & 132 & 6.8 & 13.9 & ... \\
\hline Unit price & 4.7 & 4.2 & -2.5 & .7 .7 & $\ldots$ \\
\hline
\end{tabular}

Sources; Bangledesh Bank; and staff estimates.

$1 /$ Official estimates for total imports in 1998/99 are lowet than the staff estimates presented in Appendix Table 32, because the ]atter have been adjusted to account for unrecorded imports financed by recent foreign direct investment inflows.

$2 /$ Adjusted growth rate based on data presented in Apperidix Table 32. 
Table 35. Bangladesh; Geographical Distribution of Foreign Trade, 1994/95-1997/98 (In percent of total)

\begin{tabular}{|c|c|c|c|c|}
\hline & $1994 / 95$ & $1995 / 96$ & $1996 / 97$ & $\begin{array}{r}\text { Est, } \\
1997 / 98\end{array}$ \\
\hline \multicolumn{5}{|l|}{ Exports } \\
\hline United States & 34.0 & 30.0 & 31.3 & 32.0 \\
\hline Canada & 2.0 & 2.0 & 1.7 & 2.0 \\
\hline Western Europe & 42.0 & 49.0 & 47.9 & 49.0 \\
\hline Eestern Europe & 1.0 & 1.0 & 1.3 & 1.0 \\
\hline India & 1.0 & 1.0 & 0.8 & 1.0 \\
\hline Pakistan & 1.0 & 1.0 & 1.2 & 12 \\
\hline Japan & 3.0 & 4.0 & 2.5 & 2.7 \\
\hline Hong Kang, Province of Ching & 4.0 & 4.0 & 2.8 & 3.0 \\
\hline Singapore & 1.0 & 1.0 & 0.5 & 1.0 \\
\hline Iran, Islamic Republic of & 1.0 & 1.0 & 1.2 & 1.0 \\
\hline China & 0.0 & 1.0 & 12 & 1.0 \\
\hline Other & 10.0 & 5.0 & 7.6 & 5.1 \\
\hline Total & 100.0 & 100.0 & 100.0 & 100.0 \\
\hline \multicolumn{5}{|l|}{ Imports. } \\
\hline United States & 5.0 & 5.0 & 4.5 & 5.0 \\
\hline Canada & 3.0 & 1.0 & 1.1 & 1.0 \\
\hline Western Europe & 15.0 & 11.0 & 12.7 & 13.0 \\
\hline Eastem Europe & 2.0 & 1.0 & 1.8 & 2.0 \\
\hline Indja & 10.0 & 16.0 & 13.8 & 15.0 \\
\hline Pakistan & 2.0 & 2.0 & 1.0 & 1,0 \\
\hline China & 7.0 & 10.0 & 8.6 & 10.0 \\
\hline Hong Kong, Province of Chine & 7.0 & 5.0 & 6.1 & 6.0 \\
\hline Singaport & 6.0 & 5.0 & 4,4 & 5,0 \\
\hline Korea, Republic of & 5.0 & 9.0 & 3.4 & 7.0 \\
\hline Malaysia & 1.0 & 1,0 & 2.9 & 3.0 \\
\hline Indonesia & 2.0 & 1.0 & 1.9 & 1.0 \\
\hline Theiland & 1.0 & 1.0 & 1.2 & 1.0 \\
\hline Saudi Arabia & 2.0 & 1.0 & 1.3 & 1.0 \\
\hline Anstralja & 2.0 & 1.0 & 2.5 & 2.0 \\
\hline Japsn & 13.0 & 9.0 & 8.8 & 90 \\
\hline Other & 17.0 & 24.0 & 22.0 & 18.0 \\
\hline Total & 100,0 & 100.0 & 100.0 & 100.0 \\
\hline
\end{tabular}

Source: Bangladesh Bant 
Table 36. Bangladesh: Worker's Remittances, 1994/95-1998/99

(In millions of U.S. dollars)

\begin{tabular}{|c|c|c|c|c|c|}
\hline & $1994 / 95$ & $1995 / 96$ & $1996 / 97$ & $1997 / 98$ & $\begin{array}{r}\text { Est. } \\
1998 / 99\end{array}$ \\
\hline Bahrain & 34 & 30 & 32 & 32 & 39 \\
\hline Germany & 8 & 5 & 3 & 2 & 5 \\
\hline Iran, Islamic Republic of & 0 & 0 & 0 & 1 & 0 \\
\hline Iraq & 0 & 0 & 0 & 0 & 0 \\
\hline Japan & 31 & 23 & 26 & 20 & 39 \\
\hline Knwait & $\mathrm{J} 65$ & 174 & 212 & 213 & 230 \\
\hline Libya & 1 & 0 & 0 & 1 & 0 \\
\hline Mrlaysia & 50 & 74 & 95 & 78 & 68 \\
\hline Oman & 81 & 82 & 94 & 88 & 92 \\
\hline Qatar & 72 & 53 & 53 & 58 & 64 \\
\hline Saudi Arabia & 477 & 498 & 587 & 589 & 685 \\
\hline United Arab Emirates & 81 & 84 & 90 & 107 & 125 \\
\hline United Kingdom & 47 & 41 & 56 & 65 & 54 \\
\hline United States & 112 & 115 & 157 & 203 & 239 \\
\hline Others & 39 & 38 & 70 & 68 & 66 \\
\hline Total & 1,198 & 1,217 & 1,475 & 1,525 & 1,706 \\
\hline
\end{tabular}

Source: Bangladesh Bank and Fund staff estimates.

CInternational Monetary Fund. Not for Redistribution 
Table 37. Bangladesh: Services Account, 1995/96-1998/99

(In millions of U. S. Dollars)

\begin{tabular}{|c|c|c|c|c|}
\hline & $1995 / 96$ & $1995 / 97$ & $1997 / 98$ & $\begin{array}{l}\text { Est. } 1 / \\
1998 / 99\end{array}$ \\
\hline Services ( net) & -112.9 & $\mathbf{5 5 . 9}$ & 82.2 & 92.7 \\
\hline Nonfactor services (net) & -107.0 & 163.3 & 182.3 & 228.0 \\
\hline Receipts & 626.1 & 656.4 & 707.1 & 735.6 \\
\hline Transportation & 66.4 & 86.3 & 93.0 & 92.9 \\
\hline Travel & 27.5 & 42.1 & 67.9 & 49.3 \\
\hline Other & 532.2 & 528.0 & 546.2 & 593.4 \\
\hline Payments & -733.1 & -493.1 & -524.8 & -507.6 \\
\hline Transportation & -149.1 & -165.2 & -178.5 & -190.9 \\
\hline Travel & -161.7 & -153.2 & -165.8 & -141.7 \\
\hline Other & -422.3 & -174.7 & -180.5 & -175.0 \\
\hline Investment income (net) & -5.9 & -107.4 & -100.1 & -135.3 \\
\hline Receipts & 182.1 & 88.6 & 90.8 & 91.1 \\
\hline Payments & -188.0 & -196.0 & -190.9 & -226.4 \\
\hline Interest payments & -180.5 & -155.1 & -147.2 & -154.8 \\
\hline Fnofits and dividends & -7.5 & -40.9 & -43.7 & -71.6 \\
\hline
\end{tabular}

Source; Bangladesh Bank.

1/ The official estimates of investment income payments presented in this table are significantly lower than the staff estimates embedded in Table 32, reflecting the adjusiments in staff estimates to account for service paynents on unrecorded FDI inflows. 
Table 38. Bangladesh: External Aid Commitments and Disbursements, 1994/95-1998/99

(In millions of U.S. dollars)

\begin{tabular}{|c|c|c|c|c|c|}
\hline & $1994 / 95$ & $1959 / 96$ & $1996 / 97$ & $1997 / 98$ & $\begin{array}{r}\text { Est. } \\
1998 / 99\end{array}$ \\
\hline \multicolumn{6}{|l|}{ Food Aid } \\
\hline Opening Pipeline & 133.9 & 128.0 & 100.9 & 159.8 & 118.6 \\
\hline Counnitments & 132.0 & 192,0 & 137.9 & 49.8 & 268.8 \\
\hline Disbursements & 137.0 & 138.0 & 100.9 & 99.0 & 176.9 \\
\hline Grants 1/ & 137.0 & 138.0 & 100.9 & 99.0 & 176.9 \\
\hline Loans & 0.0 & 0.0 & 0.0 & 0.0 & 0.0 \\
\hline Adjustment $2 /$ & 0.0 & 0.8 & 0.0 & 8.0 & 0.0 \\
\hline Closing pipeline & 128.9 & 122.8 & 159.8 & 118.6 & 210.5 \\
\hline \multicolumn{6}{|l|}{ Commodity Aid } \\
\hline Opening Pipsline & $\mathbf{4 4 2 . 0}$ & 498.8 & 400.8 & 29.9 & 124.3 \\
\hline Cómanitments & 354,0 & 163.1 & 170.5 & 233,0 & 362.5 \\
\hline Dishursements & 333.0 & 229.4 & 253.1 & 187.0 & 2612 \\
\hline Grants $1 /$ & 227.0 & 182.4 & 247.6 & 145.0 & 56.0 \\
\hline Loans & 106.0 & 47.0 & 15.5 & 42.0 & 205.2 \\
\hline Adjustment 2/ & -60.0 & -31.7 & -278.3 & 48.4 & -8.4 \\
\hline Closing pipeline & 403.0 & 400.8 & 29.9 & 124.3 & 2172 \\
\hline \multicolumn{6}{|l|}{ Project Aid } \\
\hline Opening Pipeline & $5,419,1$ & $5,503.8$ & $4,907.6$ & $.4,507.4$ & $4,652.7$ \\
\hline Comomitrents & $1,126.0$ & 983.6 & $1,352.8$ & $1,901.5$ & $2,017.3$ \\
\hline Distursementits & $1,269,0$ & $1,076.4$ & $1,117.1$ & $1,033.1$ & $1,035-2$ \\
\hline Grants 3/ & 526.0 & 357.0 & 387.5 & 327,1 & 373.7 \\
\hline Laans & 743.0 & 719.4 & 729.6 & 706.0 & 661.5 \\
\hline Adjustinent $2 /$ & -112.0 & -503.4 & 0.0 & -723.1 & .29 .7 \\
\hline Closing pipetine & $5,164.1$ & $4,907.6$ & $4,507.4$ & $4,652.7$ & $5,605.1$ \\
\hline \multicolumn{6}{|l|}{ Total Ajd } \\
\hline Opening Pipeline & $5,995.0$ & $6,230.6$ & $5,431.2$ & $4,697.1$ & $4,895,6$ \\
\hline Commitments & $1,612.0$ & $1,278.7$ & $1,661,2$ & $2,184.3$ & $2,648.6$ \\
\hline Disbursements & $1,739,0$ & $1,443.8$ & $1,481.1$ & $1,319.1$ & $1,473.3$ \\
\hline Grants & 890.0 & 677.4 & 736.0 & 571.1 & 659.3 \\
\hline Loans & 849.0 & 766.4 & 745.1 & 748.0 & 866.7 \\
\hline Adjustment $2 /$ & -172.0 & -634.3 & .278 .3 & .666 .7 & 38.1 \\
\hline Closing pipeline & $5,696.0$ & $5,431.2$ & $4,697.1$ & $4,895.6$ & $6,032,8$ \\
\hline
\end{tabular}

Source: Econonuic Relations Division, Ministry of Finance

1/ Imoluded in "Oficial current transfers" in the current account in Table 32; from 1996/97 onwards, data recotded as "oficial ourrent transfirs" inchude technicat assistance-related inflows and, as a result, exceed the surth of food, aid and comrnodity mid grants as recorded in this table.

$2 /$ Inoludes cancellation end thchange rate adjustments.

3/ Ineluded in "Project aid" in the capital acoount in Table 32. 
Table 39. Bangladesh: External Aid Disbursements by Donors, 1994/95-1998/99

(In millions of U.S. dolters)

\begin{tabular}{|c|c|c|c|c|c|}
\hline & $1994 / 95$ & $1995 / 96$ & $1996 / 97$ & $1997 / 98$ & $\begin{array}{r}\text { Est. } \\
1998 / 99\end{array}$ \\
\hline Bilateral donors & 915.8 & 756.9 & 717.2 & 608.8 & 638.4 \\
\hline Australia & 10.0 & 11.1 & 15.7 & 9.1 & 5.9 \\
\hline Belgium & 2.3 & 2.7 & 1.1 & 0.0 & 0.0 \\
\hline Canada & 47.1 & 24.8 & 30.4 & 21.1 & 26.8 \\
\hline China & 0.0 & 0.0 & 9.9 & 2.2 & 0.0 \\
\hline Denmark & 30.8 & 13.6 & 22.7 & 25.0 & 32.6 \\
\hline France & 30.3 & 9.7 & 27.0 & 20.6 & 10.7 \\
\hline Firland & 2.2 & 3.8 & 3.2 & 0.0 & 0.0 \\
\hline Germany & 111.7 & 64,1 & 33.8 & 40.0 & 36.7 \\
\hline India & 0.0 & 1.0 & 0.5 & 0.2 & 6.6 \\
\hline Japan & 356.5 & 331.1 & 3682 & 301.7 & 235.0 \\
\hline Kawait & 0.1 & 9.6 & 10.4 & 5.0 & 5.7 \\
\hline Netherlands & 17.9 & 32.9 & 71.9 & 25.0 & 43.1 \\
\hline Norway & 34.1 & 29.8 & 16.7 & 29.3 & 9.5 \\
\hline Sauti Arabia & 18.7 & 30.8 & 10.1 & 7.0 & 4.2 \\
\hline Sweden & 12.7 & 5.2 & 22.1 & 23.4 & 22.2 \\
\hline Switzerland & 4.9 & 1.6 & 2.5 & 2.0 & 9.3 \\
\hline United Kingdom & 53.4 & 33.3 & 20.6 & 28.0 & $\$ 2.1$ \\
\hline United Statess & 114.6 & 51.3 & 35.3 & 38.6 & 69.1 \\
\hline U.S.S.R. $1 /$ & 0.0 & 0.0 & 0.6 & 0.1 & 0.0 \\
\hline Suppliers' credits & 57.5 & 97.6 & 12.3 & 25.0 & 46.0 \\
\hline Other & 11.0 & 2.9 & 2.2 & 5.5 & 21.9 \\
\hline Multilateral donors & 823.2 & 686.9 & 764.0 & 809.8 & 834.9 \\
\hline Asian Developmenent Bank & 336.8 & 279.0 & 254.9 & 310.0 & 217.5 \\
\hline IDA & 286.0 & 225.6 & 313.8 & 327.0 & 477.0 \\
\hline European Union & 64.3 & 90.9 & 620 & 60.0 & 39.2 \\
\hline IFAD & 7.5 & 6.2 & 9.8 & 8.2 & 10.9 \\
\hline UNDP & 27.6 & 3.1 & 8.8 & 20.0 & 25.2 \\
\hline World Food Program & 36.8 & 34.3 & 18.3 & 43.2 & 82.6 \\
\hline UNICEF & 50.4 & 20.9 & 60.2 & 220 & 192 \\
\hline Eslamic Development Bank & 5.9 & 11.0 & 19.3 & 16.3 & 12.3 \\
\hline DPEC Fund & 5.6 & 15.9 & 17.4 & 3.0 & 3.5 \\
\hline Other & 23 & 0.0 & 0.0 & 0.0 & -52.5 \\
\hline Total aid disbursements & $1,739.0$ & $1,443.8$ & $14 B 1.2$ & 1418.6 & 1473.3 \\
\hline
\end{tabular}

Source: Economic Relations Division, Ministry of Finance and Fund staff projections

1/ The Balties, Russia, and other fotther Soviet Union Countries. 
Table 40. Bangladesh: External Debt, 1994/95-1998/99

(In millions of U.S. dollars, end of period)

\begin{tabular}{|c|c|c|c|c|c|}
\hline & $1994 / 95$ & I $995 / 96$ & $1996 / 97$ & $1997 / 98$ & $\begin{array}{r}\text { Est. } \\
1998 / 99\end{array}$ \\
\hline Outstanding debt (end-June) & $16,766.5$ & $15,170.4$ & $15,024.7$ & $14,033.4$ & $15,145.0$ \\
\hline Medium- and long-term debt $1 /$ & $15,970.1$ & $14,524,4$ & $14,399.1$ & $13,432.6$ & $\$ 4,540.6$ \\
\hline Food credits & 0.0 & 0.0 & 0.0 & 0.0 & 0.0 \\
\hline Aircraft loens & 89.7 & 153.1 & 148.3 & 270.2 & 251.7 \\
\hline Petroleum loatns & 0.0 & 0.0 & 0.0 & 0.0 & 0.0 \\
\hline $\mathrm{MMF} / 2$ & 687.5 & 568.1 & 440.8 & 319.6 & 353.5 \\
\hline Other & 19.2 & -75.2 & 36.6 & 11.0 & -0.8 \\
\hline Debt service payments & -594.0 & -582.5 & -602.9 & -611.9 & -597.6 \\
\hline MMF/2 & -66.5 & -71.5 & -116.6 & -108.4 & -116.3 \\
\hline Other & -527.5 & -511.0 & -486.4 & -503.5 & .481 .3 \\
\hline Principal payments & -417.2 & -402.0 & -447.8 & -464.7 & -442.8 \\
\hline $\mathrm{nMF} / 2$ & -60.0 & -66.0 & $-114,0$ & -107.0 & -111.0 \\
\hline Other & -357.2 & -336.0 & -333.8 & -357.7 & .331 .8 \\
\hline Interest payments & -176.8 & -180.5 & -155.1 & -147.2 & -154.8 \\
\hline $\mathrm{MMF} / 2$ & $-6: 5$ & -5.5 & -2.6 & -1.4 & -5.3 \\
\hline Other & -170.3 & -175.0 & -152.5 & -145.8 & -149.5 \\
\hline \multicolumn{6}{|l|}{ Debt indicators } \\
\hline \multicolumn{6}{|l|}{ Outstanding debt } \\
\hline In percent of GDP & 44.6 & 37.6 & 36.6 & 33.2 & 35.0 \\
\hline In percent of current receipts & 293.2 & 246.0 & 216.7 & 181.8 & 186.6 \\
\hline \multicolumn{6}{|l|}{ Outstanding MF credit/2 } \\
\hline In percent of GDP & 1.8 & 1.4 & 1.1 & 0.8 & 0.8 \\
\hline In percent of total debt & 4.1 & 3.7 & 2.9 & 2.3 & 2.3 \\
\hline \multicolumn{6}{|l|}{ Debt service } \\
\hline In percent of GDP & 1.6 & 1.4 & 1.5 & 1.4 & 1.5 \\
\hline In percent of current receipts & 10.4 & 9.4 & 8.7 & 7.9 & 7.8 \\
\hline \multicolumn{6}{|l|}{ Debt service to the IMF/2 } \\
\hline In percent of GDP & 0.2 & 0.2 & 0.3 & 0.3 & 0.3 \\
\hline In percent of current receipts $\mathrm{I}$ & 1.2 & 1.2 & 1.7 & 1.4 & 1.4 \\
\hline In pereent of total debt service & 11.2 & 12.3 & 19.3 & 17.7 & 18.3 \\
\hline
\end{tabular}

Source: Economic Refations Division, Ministry of Finance; the World Bank; and staff estimates.

1/Debt recorded by the Economic Relations Division of the Ministry of Finance. On an original maturity basis. 2/Excludes the MMP Trust Fund. 
Table 41. Bangladesh: Gross Official Reserves, 1994/95-1998/99

(End of period; in millions of U.S. dollars)

\begin{tabular}{|c|c|c|c|c|c|}
\hline & $1994 / 95$ & $1995 / 96$ & $1996 / 97$ & $1997 / 98$ & $1998 / 99$ \\
\hline Gold $1 /$ & 27.3 & 27,0 & 25.4 & 23.4 & 20.7 \\
\hline SDRs & 67.6 & 159.1 & 48.2 & 25.6 & 9.5 \\
\hline Foreign exchange & $2,974.7$ & $1,831.6$ & $1,619.9$ & $1,701.8$ & 1492.2 \\
\hline Other & 26.1 & 16.0 & $\ldots$ & $\ldots$ & $\cdots$ \\
\hline Total $/ 2$ & $3,069.6$ & $2,017.7$ & $1,693.5$ & $1,750.7$ & 1522.4 \\
\hline
\end{tabular}

Source: Bangladesh Bank.

1/ National valuation.

2/ The figures for total reserves may differ from the ones presented in the official balance of payments because of valuation differences. 